DOE/EA-1372

April 2003

\title{
IDAHO NATIONAL ENGINEERING AND ENVIRONMENTAL LABORATORY WILDLAND FIRE MANAGEMENT ENVIRONMENTAL ASSESSMENT
}

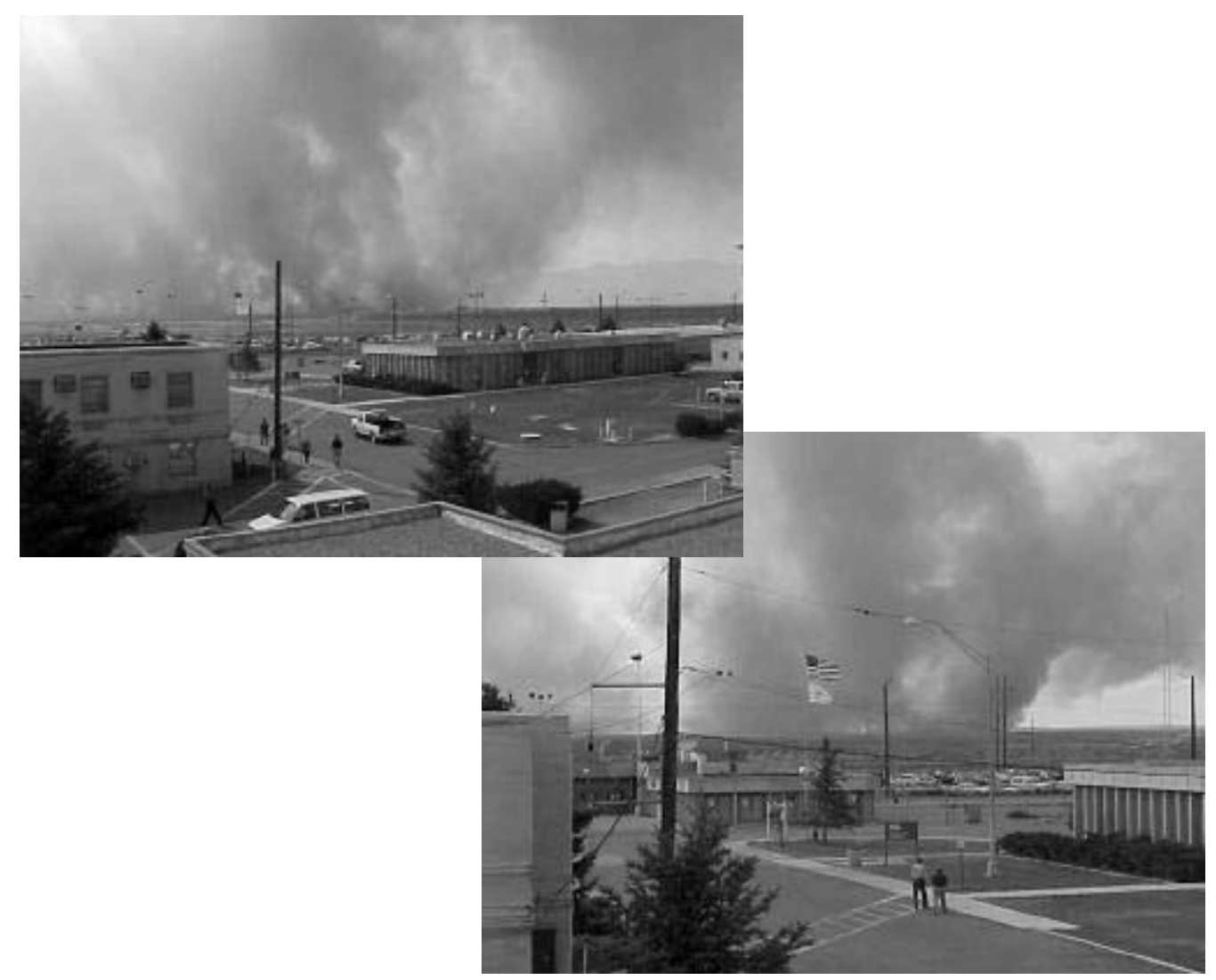




\section{U.S. DEPARTMENT OF ENERGY \\ FINDING OF NO SIGNIFICANT IMPACT FOR THE IDAHO NATIONAL ENGINEERING AND ENVIRONMENTAL LABORATORY WILDLAND FIRE MANAGEMENT ENVIRONMENTAL ASSESSMENT}

Agency: U. S. Department of Energy (DOE)

Action: Finding of No Significant Impact (FONSI)

Summary: DOE prepared an environmental assessment (EA) for wildland fire management activities on the Idaho National Engineering and Environmental Laboratory (INEEL) (DOE/EA1372). The EA was developed to evaluate wildland fire management options for pre-fire, fire suppression, and post fire activities. Those activities have an important role in minimizing the conversion of the native sagebrush steppe ecosystem found on the INEEL to non-native weeds. Four alternative management approaches were analyzed: Alternative 1 - maximum fire protection; Alternative 2 - balanced fire protection; Alternative 3 - protect infrastructure and personnel; and Alternative 4 - no action/traditional fire protection.

The EA was prepared in accordance with the Council on Environmental Quality (CEQ) Regulations for implementing the National Environmental Policy Act (NEPA) (40 CFR 15001508), and the DOE NEPA Implementing Procedures (10 CFR 1021).

During the development of the draft EA, DOE requested input from entities with expertise in wildland fire management or the management of resources affected by wildland fire management activities. The draft EA was released for a 30-day public review and comment period on September 16, 2002. DOE received comments from the U. S. Fish and Wildlife Service, the INEEL Citizens Advisory Board, the Idaho Department of Fish and Game, The Nature Conservancy, the Sagebrush Steppe Reserve Project, and five members of the public. DOE responded to those comments and revised portions of the EA, as appropriate. Based on the analysis in the EA, DOE has decided to implement a modified Alternative 2, Balanced Fire Protection Approach, as described below.

\section{Selected Action:}

DOE has decided to implement the following actions:

\section{Wildland Fire Management Committee}

DOE will create a Wildland Fire Management Committee similar to one described in Section 2.1.1 of the EA to address pre-fire and post-fire activities. DOE will select committee members during the development of the charter for the committee. DOE may request individuals from other agencies or independent technical advisors to participate on that committee.

\section{PRE-SUPPRESSION ACTIONS}

\section{Fuel Management Zones Along Improved Roads}

As appropriate, the INEEL will mow vegetation or conduct prescribed burns along the following highways and roads that pass through or border the INEEL. 
1. A minimum of 10 feet to a maximum of 300 feet on each side of State Highways 20,26 , and $20 / 26$.

2. A minimum of 10 feet to a maximum of 50 feet on each side of State Highways 22,28 , and 33.

3. A minimum of 10 feet to a maximum of 50 feet along:

a. Each side of Lincoln Boulevard and Adams Boulevard from Lincoln Boulevard to the Radioactive Waste Management Complex; and

b. Approach roads to the Central Facilities Area Gun Range Facility, Argonne National Laboratory-West, Idaho Nuclear Technology and Engineering Center, Test Reactor Area, Naval Reactors Facility, Waste Reduction Operations Complex, and the Specific Manufacturing Capabilities site areas.

4. A minimum of 100 feet to a maximum of 300 feet around the Central Facilities Area gun range.

5. A 5- to 10 - foot strip along facility perimeter roads.

\section{Fuel Management Zones Along Unimproved Roads}

No fuel management activities will occur along unimproved roads.

\section{Unimproved Road Upgrade}

The INEEL will maintain the following strategic unimproved roads as passable for $4 \mathrm{X} 4$ equipment: T-12, T-13, and Main Street from the intersection of T-13 to State Highway 20/26, $\mathrm{T}-16, \mathrm{~T}-4, \mathrm{~T}-3, \mathrm{~T}-5, \mathrm{~T}-20, \mathrm{~T}-9$, and the existing power line roads. Upgrading unimproved roads will be limited to filling ruts with gravel or dirt and leveling the fill material. Improvements will be restricted to only those segments where they are necessary.

The INEEL will install signs identifying each unimproved road at their intersection with other unimproved roads and at the head of each unimproved road.

\section{Defensible Space}

The INEEL will provide defensible space as described in Section 2.1.1 except that blading with or without sterilization will not be used, and placing gravel over areas that may require long-term weed control will be minimized. Defensible space will be provided by:

1. Maintaining a 30- to 50- foot defensible area around all INEEL buildings, structures, and significant support equipment; and

2. Maintaining a 30 -foot defensible area around parking lots, storage pads, designated buildings, designated perimeters, designated propane and fuel tanks, substations, and along the rail system within the INEEL.

\section{FIRE SUPPRESSION ACTIONS}

\section{Staged Response}

The INEEL will use a staged fire suppression response and will incorporate minimum impact suppression tactics (MIST) as specified in Section 2.1.2 of the EA whenever conditions allow, as determined by the on scene commander. Those tactics include minimum width and depth containment lines, avoiding waterways, using cold-trail tactics, and using existing roads as containment lines. 


\section{Direct Tactics}

The INEEL may use the following direct tactics:

1. Hose line application of water and/or foam suppressants on burning vegetation using offroad fire-fighting equipmènt.

2. Aerial delivery of water and/or chemical retardant using helicopters and air tankers.

3. Construction of containment lines (generally up to 24 feet unless the on scene commander determines that larger containment lines are necessary) on the fire perimeter using dozers, graders, other mechanical equipment, and hand tools.

\section{Indirect Tactics}

The INEEL may use the following indirect tactics:

1. Constructing containment lines ahead of advancing fire. This generally involves the construction of a single or double blade (generally up to 24 feet unless the on scene commander determines that larger containment lines are necessary) containment line using dozers, graders, and discs, or the widening of existing breaks.

2. Burning vegetation from a containment line to the fire edge of the advancing fire, as required.

Pockets of unburned vegetation within the fire perimeter will be preserved to the extent practicable.

\section{Parallel Tactics}

The INEEL may use the following parallel tactics:

1. Construct containment lines parallel to but further from the fire edge than in direct attack.

2. Burn the fuel between the containment line and the fire edge.

3. Construct containment lines only as large as necessary to effectively check the fire.

\section{POST-FIRE ACTIONS}

\section{Dust Suppression and Control}

The INEEL may suppress and control dust by:

1. Applying a soil tackifier and/or mulch; and/or

2. Installing water cannons or snow fences upwind of affected facilities.

\section{Site Restoration}

The INEEL will implement site restoration activities, as identified in Section 2.1.3, as necessary to determine impacts to cultural resources and ensure the establishment of a native plant community in areas disturbed by suppression activities. Until such time as a native plant community is established, the INEEL will control non-native weeds, including noxious weeds and invasive species, on those areas.

Analysis: Based on the analysis in the EA, the selected action would not have, and would likely prevent, a significant effect on the human environment within the meaning of NEPA. The term "significantly" and the significance criteria are defined by the CEQ Regulations for implementing NEPA at 40 CFR 1508.27. The significance criteria are addressed below and referenced to the corresponding analysis in the EA. 


\section{1) Beneficial and adverse impacts [40 CFR 1508.27 (b)(1)]:}

The selected action provides an approach to wildland fire management that will balance the need to minimize the size of wildland fires, thus protecting sagebrush and INEEL facilities, with the need to reduce habitat fragmentation and soil disturbance with its associated impacts on cultural resources and increased potential for the conversion of the sagebrush steppe ecosystem to nonnative weeds.

2) Public health and safety [40 CFR 1508.27 (b)(2)]:

The two primary public health and safety issues are blowing dust and the spread of radiological contamination from burned-over areas. Radiological contaminants spread by wind are at very low-levels and unlikely to cause human health and ecological concerns (Section 3.2 and 4.2.1 of the EA). The amount of blowing dust resulting from the implementation of the selected action may be greater than Alternative 1 because of the use of MIST tactics in some situations. However, the trade-off of using MIST instead of an aggressive fire response is the reduced chance of invasion of cheatgrass and, therefore, decreased fire frequency and associated blowing dust events.

\section{3) Unique characteristics of the geographical area [40 CFR 1508.27 (b)(3)]:}

The INEEL has been a federal reservation with restricted public access since the mid-1940s. A result of the restricted public access is a well-preserved cultural resources record within the boundary of the INEEL (Section 3.5 of the EA). In addition, the limited access has resulted in the INEEL containing the largest remnant of undeveloped, un-grazed sagebrush steppe ecosystem in the Intermountain West (Section 3.4 of the EA). The selected action is intended to conserve the unique characteristics of the INEEL while protecting INEEL facilities from wildland fire.

\section{4) Degree to which effects on the quality of the human environment are likely to become} highly controversial [40 CFR 1508.27 (b)(4)]: The analysis of the selected action, including information gained through consultation with various entities with expertise in resource management and public comment, indicates the proposed action is not highly controversial. However, not taking action could contribute to the eventual loss of the sagebrush steppe ecosystem and that would be highly controversial.

5) Uncertain or unknown risks on the human environment [40 CFR 1508.27 (b)(5)]: The analysis indicates no unique, uncertain, or unknown risks to, or effects on the human environment will result from impacts associated with implementing the selected action.

\section{6) Precedent for future actions [40 CFR 1508.27 (b)(6)]:}

The selected action does not set a precedent for future action that may have significant effects, or represent a decision in principle about a future consideration.

\section{7) Cumulatively significant impacts [40 CFR 1508.27 (b)(7)]:}

The analysis indicates the selected action, when combined with present, past, and reasonably foreseeable future actions, would result in less cumulative impact to the overall landscape in terms of cultural resources and the potential to convert sagebrush steppe to non-native annual weeds than if DOE continues its current wildland fire management strategy. The Bureau of Land Management is also concerned with the irreversible conversion of sagebrush steppe to nonnative annual weeds and is in the process of analyzing the potential impacts of a new 
management strategy for public lands that responds to ecological linkages between fire and fuel management. The INEEL is surrounded by those public lands and is part of the landscape evaluation BLM is performing. That new management direction may also reduce, from current levels, the impacts from fire management activities on public land surrounding the INEEL and help minimize the conversion of sagebrush steppe communities to non-native annual weeds.

8) Effect on cultural or historical resources [40 CFR 1508.27 (b)(8)]:

While implementation of the selected action may have adverse impacts to cultural resources during wildfire suppression, those impacts would be reduced by the implementation of MIST. Advanced planning and coordination by the Wildland Fire Management Committee would also minimize impacts to cultural resources during pre- and post-suppression activities (Section 4.2.4 of the EA).

9) Effect on threatened or endangered species or critical habitat [40 CFR 1508.27 (b)(9)]: The analysis indicates no threatened or endangered species or critical habitat will be adversely impacted by the selected action (Appendix D, response to FWS comment \#1). Implementing the selected action is intended to conserve habitat critical to sagebrush-obligate species of concern including the greater sage grouse and northern sagebrush lizard.

10) Violation of Federal, State, or Local law [40 CFR 1508.27 (b)(10)]:

None of the actions identified in the selected action will be conducted in such a manner that will violate Federal, State or Local laws (Section 6 of the EA).

Determination: Based on the analysis presented in the attached EA, I have determined that the selected action does not constitute a major federal action significantly affecting the quality of the human environment. Therefore, preparation of an environmental impact statement is not required.

Issued at Idaho Falls, Idaho on this $24^{\text {th }}$ day of Apric , 2003.

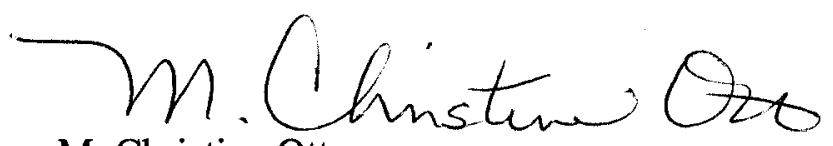

M. Christine Ott

Acting Deputy Manager, Idaho Operations Office

Copies of the EA and FONSI are available from: Brad Bugger, Office of Communications, MS-1214, Idaho Operations Office, U. S. Department of Energy, 850 Energy Drive, Idaho Falls, Idaho, $83403-3189$, or by calling (208) 526-0833 or the toll-free INEEL citizen inquiry line (800) 708-2680.

For further information on the NEPA process contact: Jack Depperschmidt, Deputy NEPA Compliance Officer, MS-1216, U. S. Department of Energy, 850 Energy Drive, Idaho Falls, Idaho, 83403-3189, (208) 526-5053. 


\title{
IDAHO NATIONAL ENGINEERING AND ENVIRONMENTAL LABORATORY WILDLAND FIRE MANAGEMENT ENVIRONMENTAL ASSESSMENT
}

\author{
Published April 2003
}

Prepared for the

U.S. Department of Energy

Idaho Operations Office 


\section{CONTENTS}

ACRONYMS

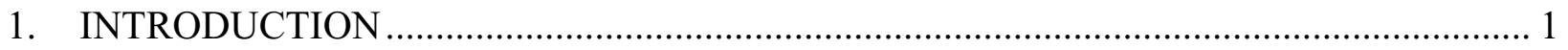

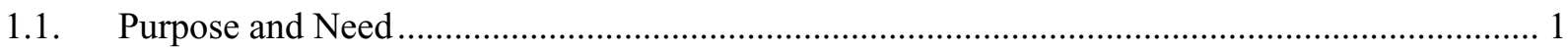

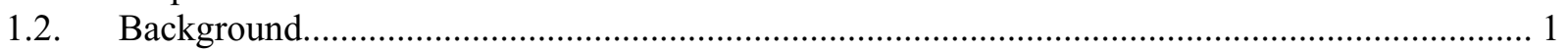

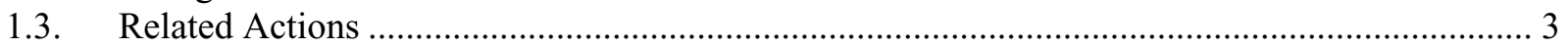

1.4. Management Goals and Objectives ................................................................................. 4

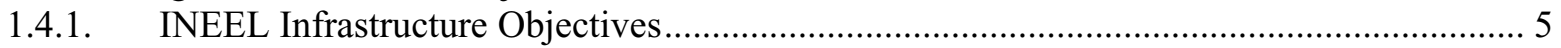

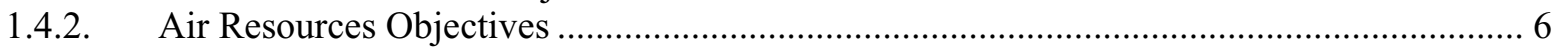

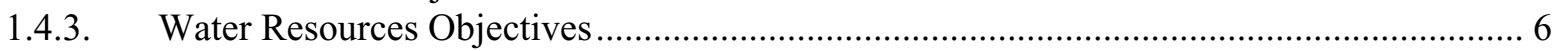

1.4.4. Wildlife/Habitat Resources Objectives.................................................................... 7

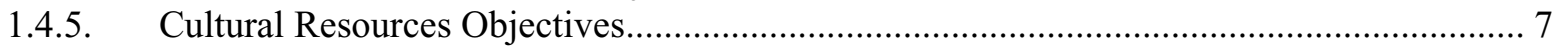

2. DESCRIPTION OF ALTERNATIVES …............................................................... 9

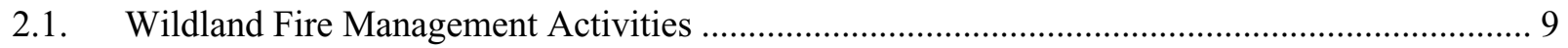

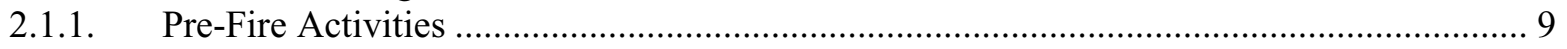

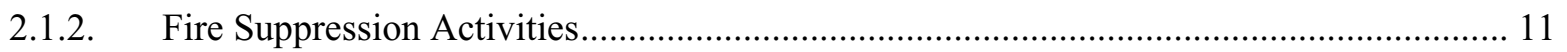

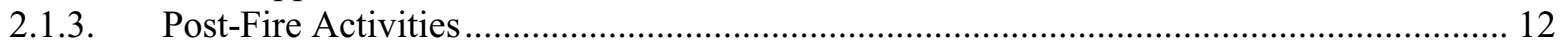

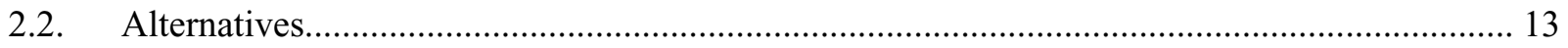

2.2.1. Alternative 1 - Maximum Fire Protection Approach ..................................................... 13

2.2.2. Alternative 2 - Balanced Fire Protection Approach....................................................... 13

2.2.3. Alternative 3 - Protect Infrastructure and Personnel Safety Approach............................. 14

2.2.4. Alternative 4 - No Action or Traditional Fire Protection Approach ................................ 14

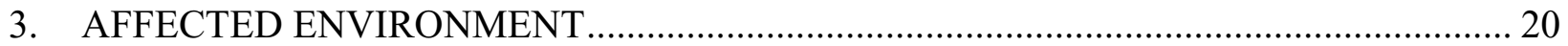

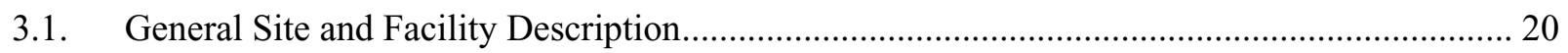

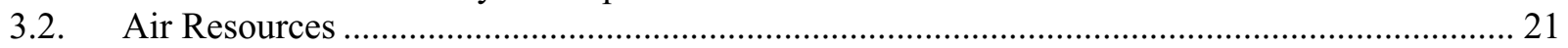

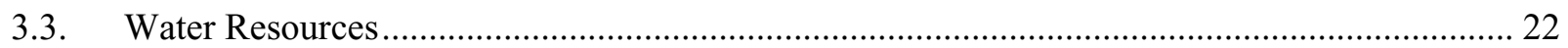

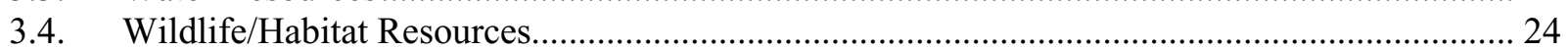

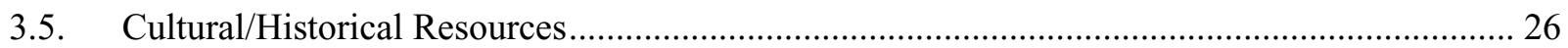

3.6. Areas of Previous Wildland Fire Response Impacts ............................................................ 27

4. ENVIRONMENTAL CONSEQUENCES ............................................................. 29

4.1. Alternative 1 - Maximum Fire Protection Approach ............................................................. 29

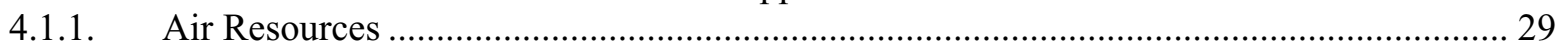

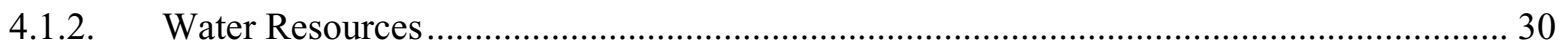

4.1.3. Wildlife/Habitat Resources.................................................................................. 30

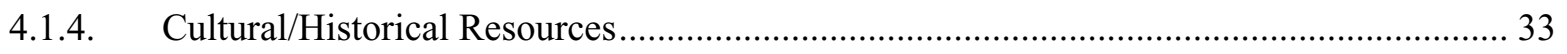

4.2. Alternative 2 - Balanced Fire Protection Approach.......................................................... 33

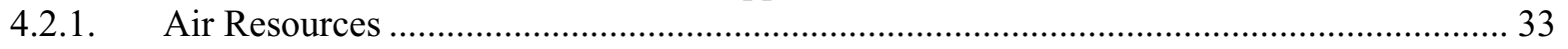

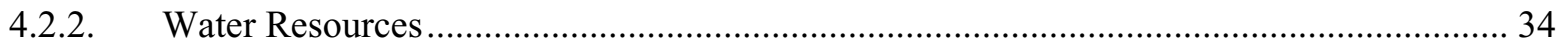

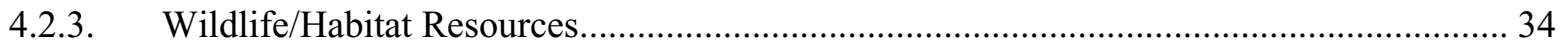

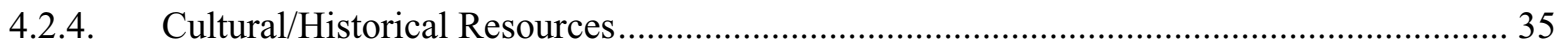

4.3. Alternative 3 - Protect Infrastructure and Personnel Safety Approach.................................... 35

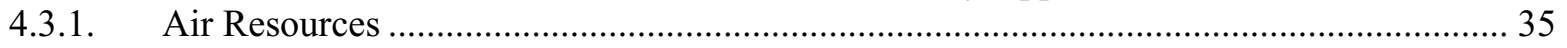

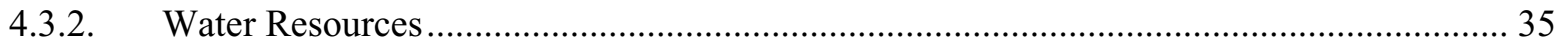

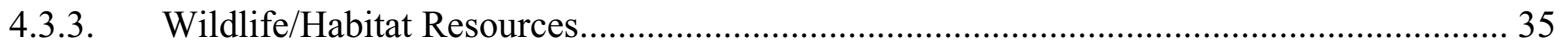

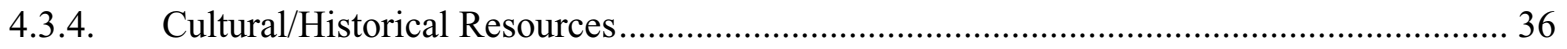

4.4. Alternative 4-No Action or Traditional Fire Protection Approach....................................... 36

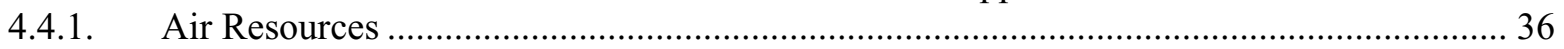

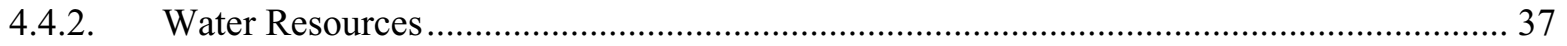




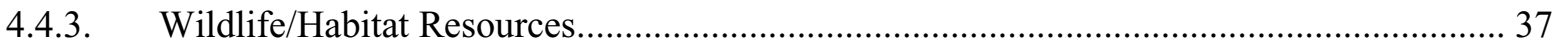

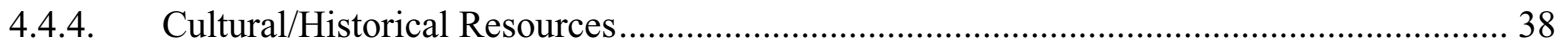

5. COORDINATION AND CONSULTATION ............................................................ 48

6. PERMITS AND REGULATORY REQUIREMENTS .................................................. 49

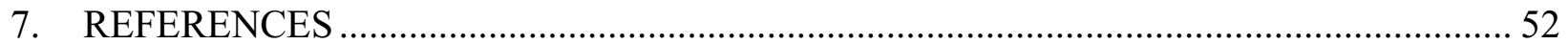

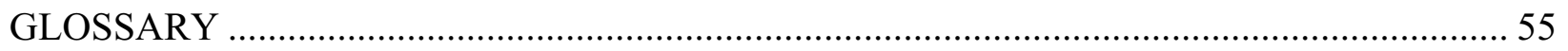

APPENDIX A - VEGETATION SURVEY ….............................................................. 56

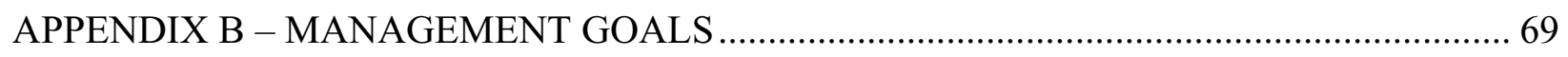

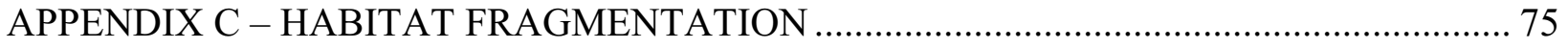

APPENDIX D - COMMENT RESPONSE ….............................................................. 80

\section{FIGURES}

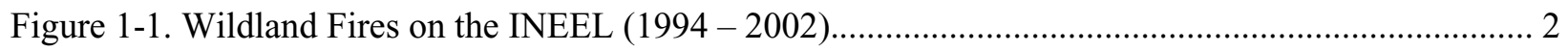

Figure 3-1. Illustration showing the INEEL and site areas in southeastern Idaho. ............................... 20

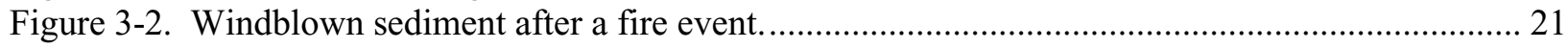

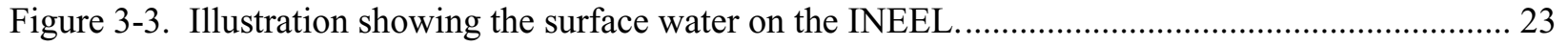

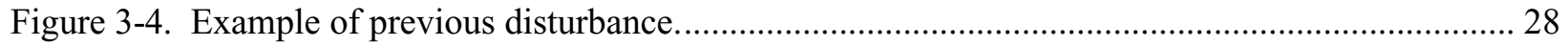

Figure 3-5. Containment line showing larger soil "ricks" and little recovery of native perennial vegetation

\section{TABLES}

Table 1-1. Federal wildland fire guiding principles ...................................................................... 5

Table 2-1. Comparison of INEEL wildland fire management strategies and actions - pre-fire,

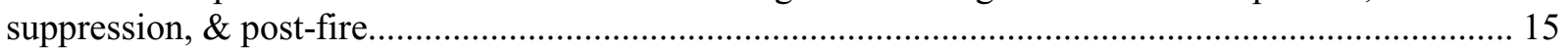

Table 3-1. SCAs and soil contamination levels modeled for fire and post-fire releases ......................... 23

Table 3-2. Federal and state-listed threatened, endangered, candidate or sensitive species ocurring or

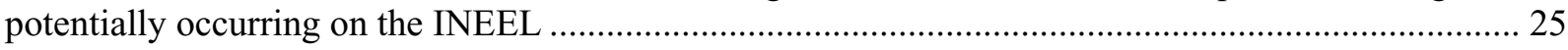

Table 4-1. Summary of environmental impacts and across alternatives for wildland fire management activities on air, water, wildlife/habitat, and cultural/historical resources of the INEEL...................... 38

Table 4-2. Evaluation matrix for natural resource objectives across alternatives - a relative comparison 45 


\section{ACRONYMS}

\begin{tabular}{ll} 
ANL-W & Argonne National Laboratory - West \\
BLM & Bureau of Land Management \\
CAA & Clean Air Act \\
CERCLA & Comprehensive Environmental Response Compensation and Liability Act \\
CFA & Central Facilities Area \\
CFR & Code of Federal Regulation \\
CRMO & Cultural Resource Management Office \\
DOE & Department of Energy \\
DOE-ID & DOE Idaho Operations Office \\
EIS & Environmental Impact Statement \\
EPA & Environmental Protection Agency \\
ESA & Endangered Species Act \\
FEIS & Final Environmental Impact Statement \\
FWS & Fish and Wildlife Service \\
GIS & Geographical Information System \\
IDAPA & Idaho Administrative Procedure Act \\
INEEL & Idaho National Engineering and Environmental Laboratory \\
INTEC & Idaho Nuclear Technology and Engineering Center \\
MIST & Minimum impact suppression tactics \\
NEPA & National Environmental Policy Act \\
NERP & National Environmental Research Park \\
NHPA & National Historic Preservation Act \\
NOAA & National Oceanic and Atmospheric Administration \\
PBF & Power Burst Facility \\
PSD & Prevention of significant deterioration \\
RWMC & Radioactive Waste Management Complex \\
SCA & Soil contamination area \\
SMC & Specific Manufacturing Capability \\
T\&E & Threatened and endangered \\
TAN & Test Area North \\
TRA & Test Reactor Area \\
\hline
\end{tabular}




\section{IDAHO NATIONAL ENGINEERING AND ENVIRONMENTAL LABORATORY WILDLAND FIRE MANAGEMENT ENVIRONMENTAL ASSESSMENT \\ 1. INTRODUCTION}

\subsection{Purpose and Need}

The Idaho National Engineering and Environmental Laboratory (INEEL) is a U.S. Department of Energy (DOE)-managed reservation occupying about 890 square miles in southeastern Idaho. The INEEL lies within the upper Snake River Plain sagebrush steppe ecosystem ${ }^{l}$. Much of the sagebrush steppe ecosystem throughout the west has been segmented and lost to development and agriculture. The remaining sagebrush steppe ecosystem and the habitat it provides is threatened with irreversible conversion to non-native annual weeds by rangeland management practices in combination with the natural fire process. The sagebrush steppe of the INEEL is now threatened and DOE must evaluate its management role and alternatives available to preserve this important component of the western ecosystem.

\subsection{Background}

The potential for wildland fires on the INEEL is routinely high because of rapid growth of grasses and brush during cool, wet springs followed by extended dry weather in the late spring and early summer months. The result is dry vegetation, accumulating year after year providing large quantities of fuel for fires. Fire is a natural component of the ecosystem. Over time, the climax sagebrush steppe vegetation on the INEEL has repeatedly burned and recovered through natural successional stages. Under natural conditions, the climax sagebrush steppe vegetation is composed of native shrubs, and annual and perennial grasses and broadleaf herbs called forbs. When this native vegetation type burns the following general response is expected: sagebrush is killed, perennial grasses and forbs re-sprout and annuals survive as seed that germinates when conditions are favorable. Generally, over the course of several years, seed from surviving sagebrush in unburned areas is distributed by the wind, seedling sagebrush are established, and after about 5 years of growth, produce seeds of their own. The maturing sagebrush competes with other native plants for water and nutrients and a natural balance is established. As the plant community matures, the fuel load increases and the stage is set for another fire and recovery cycle. Researchers estimate that tThe entire cycle typically takes between 40 and 70 years.

The introduction of non-native annual plants, such as cheatgrass, into the sagebrush steppe ecosystem has altered the natural fire frequency and recovery cycle. Cheatgrass sprouts from seed in the spring, fall or winter and goes to seed and dries by early summer. When cheatgrass is present and fire occurs, the cheatgrass seed quickly germinates to compete for moisture and nutrients with native seeds and surviving plants. As the vegetation recovers from the fire, cheatgrass represents a higher percent of the fuel load and tends to create a continuous carpet of fuel that is extremely prone to fire. If there is another fire before the sagebrush matures and produces seed, sagebrush will disappear from the plant community. As the frequency of fire increases, cheatgrass will continue to increase in this fire-altered environment. Without intervention, the sagebrush steppe ecosystem and the habitat it provides may be irretrievably lost. The U.S. Fish and Wildlife Service (FWS) has received six petitions to list as threatened or endangered under the Endangered Species Act (ESA), various populations of sage grouse. One of those petitions requests listing the Eastern Subspecies of the Greater Sage Grouse, which inhabits the INEEL, as an

\footnotetext{
${ }^{1}$ Italicized words are included in the Glossary on page 55.
} 
endangered species. Wildland fires, along with pre- and post-fire suppression vegetation management could influence the life cycle of sage grouse and other species that rely on stands of sagebrush for food and cover.

From 1994 to 2000 about 130,000 acres of the INEEL and several hundred thousand acres of Bureau of Land Management (BLM)-managed public land burned on the Snake River Plain of southeast Idaho (see Figure 1-1). The fires on the INEEL threatened facilities and exposed soils to wind erosion, resulting in severe dust storms that impact operations and create traffic hazards for weeks.

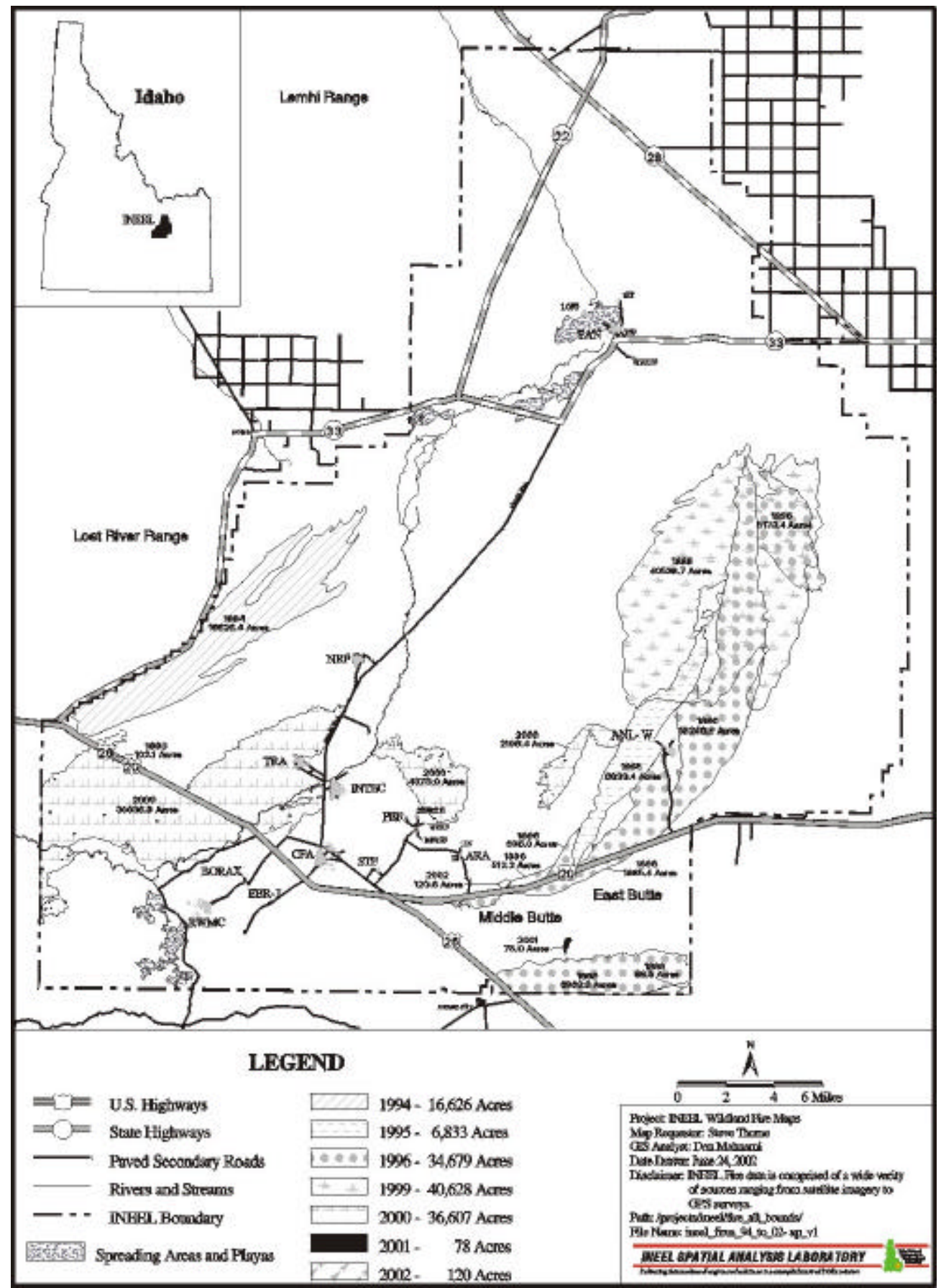

Figure 1-1. Wildland fires on the INEEL (1994-2002). 
Most of the acreage on the INEEL that burned between 1994 and 2000 is recovering well with the exception of sagebrush. Most native plant species are recovering and represent most of the plant composition, but cheatgrass is a component. In isolated areas, cheatgrass and other annual non-native weeds are dominant. If this situation persists and no changes are made to wildland fire pre-fire, fire suppression, and post-fire tactics and there is no intervention to reduce cheatgrass and manage for sagebrush, the stage may be set for an uncontrollable transition from sagebrush steppe to cheatgrass. Soil erosion and dust levels are-continueing to improve-decline as vegetation recovers.

\subsection{Related Actions}

In October 2000, the Secretary of Energy directed three actions aimed at improving capabilities within DOE to prevent and respond to wildland fires, one of which was to conduct a complex wide initial joint review of the adequacy of fire safety programs and related emergency management capabilities. The DOE | Offices of Independent Oversight and Performance Assurance, Security and Emergency Operations, and Environment, Safety and Health conducted this review between October 15, and December 15, 2000. The review activities included assessing the abilities of selected DOE sites to prevent and respond to wildland fires and providing recommendations for (a) pertinent site-specific and DOE-wide improvements, and (b) the scope and conduct of a comprehensive follow-on fire safety review.

The review indicated that the sites had a variety of plans, procedures, and resources in place for preventing and responding to wildland fires, with some sites having implemented exemplary practices in these areas. This is consistent with DOE's successful record to date in protecting facilities from wildland fires, which reflects solid basic capabilities of fire protection programs across the DOE complex. The review also identified several areas in need of additional management attention to strengthen the Department's wildland fire response capabilities. Actions that are appropriate at the INEEL include:

- Evaluate and document risk from, and potential consequences of, wildland fires

- Expand the Fire department baseline needs to reflect wildland fire response needs

- Prepare fire response plans that adequately address and implement procedures for wildland fire prevention and mitigation

- Implement or expand fire department and emergency management self-assessments to include an assessment of wildland fire prevention and response.

The details of the initial joint review can be found in the associated report "Initial Joint Review of Wildland Fire Safety at DOE Sites, December 2000."

In addition, INEEL's “Wildland Fire Management Guide "," provides general fire management information and recommended practices to those organizations directly involved in the preparedness for, prevention of, response to, and recovery from wildland fires on the INEEL. It is based on the criteria of the National Fire Protection Association Pamphlets 295, "Standard for Wildfire Control," and 299, "Protection of Life and Property from Wildfire." However, the INEEL does not currently maintain a land management plan similar to other federal agencies managing large areas of federal lands, that can be used as a basis for the development of fire management policy and objectives related to natural and cultural resources. This Environmental Assessment describes the analysis of various management approaches related to implementation of alternative wildland fire management alternatives for inclusion in this guide.

Bureau of Land Management Environmental Impact Statement - BLM is preparing an Environmental Impact Statement (EIS) to analyze the potential impacts of a new direction in public lands management that responds to the ecological linkages between fire and fuels management activities on

\footnotetext{
${ }^{1}$ Guide (GDE)-7063 “INEEL Wildland Fire Management Guide," Internal Guidance Document, BBWI.
} 
public lands. The new direction in fire and fuels management will integrate several disciplines and emerging technologies that were not available when the district's existing land use plans were originally prepared. These include recent developments in landscape science (such as geographical information systems [GIS]), current ecological theory regarding ecosystem states and transitions, wildlife strongholds and the impacts of fragmented habitats on wildlife populations, as well as using recently developed, and future, technologies to improve the health of public lands. The BLM proposes to amend the district's twelve existing land use plans with new direction to coordinate fire and fuels management in the district. The land use plan amendments will establish a broad ranging, 'big-picture,' landscape-level management direction recognizing that present ecological health is the cumulative product of past influences. Public lands managed by the BLM are adjacent to most of the INEEL boundary.

Because BLM is also engaged in a wildland fire planning effort, DOE and BLM have been coordinating efforts. That coordination lead to an initial decision to include the INEEL in the BLM EIS and identify it as a Category " $\mathrm{B}$ " Polygon meaning that wildland fire is not desired and aggressive fire suppression tactics would be employed. However, if DOE makes a decision based on this EA that would change the "B" polygon designation, DOE will work with BLM to revise the designation in their EIS.

Sagebrush Steppe Ecosystem Reserve - DOE signed a memorandum of agreement with the BLM, FWS, and the Idaho Department of Fish and Game on July 17, 1999, to set aside a portion of the INEEL as a sagebrush steppe reserve (hereinafter the "Reserve"). The Reserve covers about 73,000 acres on the northwest corner of the INEEL. After discussion at the Secretary of Interior and Secretary of Energy level, the BLM was designated as the lead agency in preparing a natural resources management plan that would outline how the area would be managed in the future to retain the characteristics of a healthy sagebrush steppe ecosystem. The overall objectives of the natural resources management plan are to establish specific goals and make management practice recommendations necessary to achieve the objectives set forth in the Proclamation for the Reserve, identify data gaps and research opportunities on the Reserve, and establish vegetation and wildlife management guidance, objectives, policies, and management practices. The BLM plans to complete the Natural Resource Management Plan in August 2003. Presently, the wildland fire management activities for the Reserve would be the same as those identified in this EA for the rest of the INEEL. If the management plan and associated EA for the Reserve indicates the need for a wildland fire strategy that differs from an alternative selected based on this EA, that strategy would be incorporated into the INEEL's wildland fire management.

\subsection{Management Goals and Objectives}

The DOE realizes that as a first priority, no resource or property value is worth endangering peoplehuman life or public safety. The following guiding principles from the Federal Wildland Fire Policy (see Table 1-1) reflect this basic commitment. The policy also recognizes the second priority is to protect resources and property, based on the relative values of property and resources and, being realistic, the ability of an agency to fight severe wildfire. DOE is a signatory to this policy and supports the concepts discussed in the Federal Wildland Fire Management Policy for the "integration of wildland fire into our land management planning and implementation activities". The policy further states, "These "umbrella" Federal policies do not replace existing agency-specific policies, but will compel each agency to review its policies to ensure compatibility" (Review and Update of the 1995 Federal Wildland Management Policy 2001). The following sections provide the INEEL specific management goals and objectives for INEEL's Infrastructure, Fire Department and Fire Marshall organizations (hereinafter referred to as INEEL Infrastructure) and air, water, wildlife/habitat, and cultural resources.

While independently recognized as having a well defined and comprehensive fire safety program, DOE has not finalized its policies and guidance on wildland fire management. The Department is also not 
Table 1-1. Federal wildland fire guiding principles.

- Firefighter and public safety is the first priority in every fire management activity.

- The role of wildland fire as an essential ecological process and natural change agent will be incorporated into the planning process. "Federal" agency land and resource management plans set the objectives for the use and desired future condition of the various public lands.

- Fire management plans, programs, and activities support land and resource management plans and their implementation.

- Sound risk management is a foundation for all fire management activities. Risks and uncertainties relating to fire management activities must be understood, analyzed, communicated, and managed as they relate to the cost of either doing or not doing an activity. Net gains to the public benefit will be an important component of decisions.

- Fire management programs and activities are economically viable, based upon values to be protected, costs, and land and resource management objectives. "Federal" agency administrators are adjusting and reorganizing programs to reduce costs and increase efficiencies. As part of this process, investments in fire management activities must be evaluated against other agency programs in order to effectively accomplish the overall mission, set shortand long-term priorities, and clarify management accountability.

- Fire management plans and activities are based upon the best available science. Knowledge and experience are developed among all wildland fire management agencies. An active fire research program combined with interagency collaboration provides the means to make this available to all fire managers.

- Fire management plans and activities incorporate public health and environmental quality considerations.

- "Federal, "State", Tribal, and local interagency coordination and cooperation are essential. Increasing costs and smaller work forces require that public agencies pool their human resources to successfully deal with the ever increasing and more complex fire management tasks. Full collaboration among "Federal" agencies and between the "Federal" agencies and "State", local, and private entities results in a mobile fire management work force available to the full range of public needs.

- Standardization of policies and procedures among "Federal" agencies is an ongoing objective. Consistency of plans and operations provides the fundamental platform upon which "Federal" agencies can cooperate and integrate fire activities across agency boundaries and provide leadership for cooperation with "State" and local fire management organizations.

1. Review and Update of the 1995 Federal Wildland Management Policy 2001.

required by law to have a comprehensive body of wildland management policies similar to those used by the BLM or the U.S. Forest Service. Furthermore, no funds are directly currently appropriated to the INEEL for the purposes of land management including activities such as fuel load management, fire response and recovery, habitat protection, or basic environmental research necessary to understand the effects of fire in the local environment. These activities are funded at the Laboratory level using overhead funding.

Nevertheless, the INEEL has historically maintained a highly effective wildland fire response capability and, as a prudent best management practice, conducts its land management activities consistent with the policies and guidance of the Federal land management agencies, including dedicated environmental research and management. However, the consequence of using overhead funding to conduct these activities causes the Laboratory to continually balance competing needs with resources and shift those resources as priorities dictate. Therefore, the extent to which the Laboratory can commit to the alternatives described in this document must be continually evaluated in the context of overall needs and resources as the Laboratory strives to accomplish its clean-up and nuclear energy missions.

\subsubsection{INEEL Infrastructure Objectives}

The INEEL's Infrastructure wildland fire management goal is focused on protecting INEEL resources physical assests (personnel, physical property, remediation investments) and limiting the interruptions of day-to-day laboratory operations that can result from wildland fire. This includes pre-fire objectives to maintain defensible spaces, aggressive fire suppression objectives to limit the size and duration of wildland fires, and timely rehabilitation of fire areas to minimize dust and soot impacts on personnel and equipment.

To achieve this goal, wildland fire management objectives include the following:

- Firefighter and public safety. No wildland fire situation, with the possible exception of threat to human survival, requires the exposure of firefighters to life-threatening situations.

- Minimize impact to INEEL structures, systems, and components.

- Minimize impact on natural and cultural resources. 
- Prudent expenditure of allocated resources.

- Implement a protective and effective wildland fire education/prevention/trespass program.

- Integrate cooperative wildland fire management actions with surrounding wildland fire management agencies and organizations.

- Timely rehabilitation of burned areas and repair of resource damage caused by fire suppression activities.

In addition to these overall objectives, specific objectives include:

- Maintain defensible space around improved property.

- Inspect, improve and maintain roads as necessary to ensure emergency response vehicles can access INEEL wildland fires in a timely manner. Roads can also support fire suppression operations by providing a firebreak or, defensible anchor points for indirect fire suppression activities.

- Control all wildland fires within their first burning period (that is, before 10:00 a.m. the following day) using an aggressive initial attack with direct and indirect fire suppression tactics as appropriate.

- Controlling fires in their early stages to:

- Maximize resource protection

- Minimize fire suppression resources and operations interruptions

- Minimize risk of burning soil contamination areas (SCAs)

- Minimize power interruption from wildland fire

- Minimize potential for INEEL wildland fires to impact adjacent public and private lands

- Minimize the need for rehabilitation resources

- Rehabilitate burned areas as necessary to control dust and minimize effects on INEEL personnel, equipment and operations.

\subsubsection{Air Resources Objectives}

The goal for management of air resources on the INEEL is to comply with all federal and state air regulations. However, federal and state air regulations are only relevant to pre- and post-fire activities; regulations do not apply to wildfire emissions or emergency response actions, such as bulldozing containment lines, or lighting backfires. As a general practice, it is the goal of INEEL operations to minimize emissions of pollutants to the atmosphere to the extent practicable. With respect to wildfires and wildfire prevention, objectives to meet these goals include:

- Plan and conduct pre-fire and post-fire activities to minimize dust generation

- Minimize, to the extent practicable, dust generation during fire suppression activities

- Prevent wildfires to the extent possible

- Minimize extent of wildfires, and therefore, emissions

- Prevent or minimize wildfires burning through SCAs

- If fires do burn through SCAs, apply measures to minimize spread of contaminated soil after the fire.

\subsubsection{Water Resources Objectives}

The following goals provide the basis for protecting the INEEL's water resources: (1) conduct research, environmental remediation, and operations in a manner that protects unique natural resources of the INEEL, (2) manage water resources in a responsible manner to protect the water resource for current and future use, and (3) design, construct, and operate DOE facilities so that the environment is protected from the impacts of natural phenomena, such as regional flood hazards, and wildland fires. 
The following water resources management objectives implement these goals:

- Minimize erosion

- Minimize sedimentation

- Minimize pollutant exposure

- Comply with applicable regulations

- Use fiscal resources responsibly.

\subsubsection{Wildlife/Habitat Resources Objectives}

The INEEL contains the largest remnant of undeveloped, ungrazed sagebrush steppe ecosystem in the Intermountain West (DOE 1997a). That ecosystem has been identified as critically endangered with less than two percent remaining in the western U.S. (Noss et al. 1995, Saab and Rich 1997). The INEEL is also designated as a National Environmental Research Park (NERP). A NERP is an outdoor laboratory for evaluating the environmental consequences of energy use and development as well as strategies to mitigate those effects.

The goal of ecological resource management on the INEEL is to perpetuate and protect a large, unfragmented native sagebrush steppe ecosystem, respond to existing executive orders, and federal, state, and DOE mandates for protecting biological resources, and support NERP objectives. Recognizing that fire is a natural ecosystem process, wildland fire management can protect ecological resources from damage by wildland fire and/or pre-fire, fire suppression and post-fire activities. Specific objectives include:

- Limit the size of unwanted wildland fires that put ecological resources at risk

- Maintain a natural fire cycle and landscape-scale ecosystem diversity ${ }^{1}$

- Reduce the need for rehabilitation following fire suppression

- Protect sage grouse and other sagebrush-obligate species and their habitat

- Prevent habitat loss and habitat fragmentation

- Maintain as much of the existing sagebrush steppe ecosystem as possible

- Maintain plant genetic diversity

- Protect unique ecological research opportunities

- Prevent invasion of non-native species, including noxious weeds.

\subsubsection{Cultural Resources Objectives}

Cultural resource management on the INEEL is viewed as a dynamic process with some goals being accomplished each year, and new objectives being added in response to changing conditions. The goal of the INEEL's Cultural Resource Management Office (CRMO) is to reduce or eliminate impacts to cultural resources from INEEL activities, including those from wildland fires.

With respect to wildfires and wildfire prevention, objectives to meet these goals include:

- Preventing damage to cultural resources through advanced planning and integration with infrastructure and fire department activities

- If damage to cultural resources will be unavoidable, minimizeMinimizing damage to cultural resources through consultation, advanced planning, and integration with infrastructure and fire department activities, if damage to cultural resources is unavoidable

\footnotetext{
${ }^{1}$ For purposes of this EA, natural fire cycle means eliminating fires on burned areas for 70 to 100 years to allow big sagebrush, especially the $A$. wyomingensis stands, sufficient time to re-establish. On a landscape scale, this means ensuring there are sufficient mature stands of sagebrush to provide for sagebrush obligate species.
} 
- Conducting fire and fire suppression damage assessments to determine necessary mitigation

- Eliminate-Eliminating or significantly reduce-reducing the need for construction of containment lines during wildland fires and post-fire rehabilitation in archaeologically sensitive areas. 


\section{DESCRIPTION OF ALTERNATIVES}

This section of the environmental assessment provides an overview of how different INEEL wildland fire management strategies relate to each other. Each management strategy discusses pre-fire, fire suppression and post-fire activities such as creating defensible space around facilities and SCAs, implementing minimum impact suppression tactics (MIST), using water cannons and "snow" fences to prevent blowing dust, and restoring soil damaged by fire response activities (Section 2.1). The document presents four different approaches or alternatives to wildland fire management at the INEEL: (1) Maximum Fire Protection Approach - Alternative 1, (2) Balanced Fire Protection Approach - Alternative 2, and (3) Protect Infrastructure and Personnel Safety Approach - Alternative 3 (see Section 2.2). The details of each alternative are found in Table 2-1. In addition, this document considers No Action or the Traditional Fire Protection Approach as Alternative 4.

The wildland fire management activities are discussed in detail in the following sections under Pre-Fire, Fire Suppression and Post-Fire activities (see inset).

\subsection{Wildland Fire Management Activities}

\subsubsection{Pre-Fire Activities}

Fuel Management Zones - Fuel management zones are defined as wildland areas that are maintained with reduced fuel levels to limit flame lengths and the spread of fire across an area. Fuel management zones increase the probability that wildland fires can be controlled when they encounter the reduced fuel load zone. Fuel management zones provide separation between large segments of wildland habitat from areas with human-caused fire history, such as along roadways.

Wildfire Management Activities

- Pre-Fire Activities

- Implementing fuel management zones

- Improving unimproved roads

- Creating defensible space

- Establish a Wildland Fire Management Committee

- Suppression Activities

- Implementing a staged response

- Implementing direct, indirect, or parallel tactics

- Implementing MIST

- Post-Fire Activities

- Controlling and suppressing dust

- Implementing site restoration

- Establish a Wildland Fire Management Committee

Fuel management zones would be treated to reduce fuel loading by such methods as (1) periodic mowing vegetation with rubber tired mowers, (2) burning vegetation with prescribed fire, or (3) allowing livestock grazing.

Road Improvements (unimproved roads - see inset) - A rapid, aggressive, initial attack of wildland fires is critical to achieve an early fire suppression objective. The INEEL could maintain a network of passable roads that allows emergency access to all sections of the INEEL wildlands. Upgrading unimproved roads would be limited to filling ruts with gravel or dirt and leveling the fill material. Generally, blading or fill is necessary to remove obstacles that restrict or make passage difficult such as extensive washouts, rutting, or dunes. Improvements would be restricted to only those segments where they are necessary.

\section{Road Designations}

Improved roads are United States and
State Highways (such as US Hwy 20/26,
20 and State Hwy 22 and 33 ) bisecting the
site, and INEEL interior roads, site area
approach roads and streets and gravel
roads.
Unimproved roads are those INEEL dirt
and two-track roads and some trails, often
designated as "T" roads (such as T-1, T-5,
T-20).

Improved roads are United States and State Highways (such as US Hwy 20/26 20 and State Hwy 22 and 33) bisecting the site, and INEEL interior roads, site area approach roads and streets and gravel

Unimproved roads are those INEEL dirt designated as " $\mathrm{T}$ " roads (such as $\mathrm{T}-1, \mathrm{~T}-5$, T-20).

Defensible Space - Defensible spaces are areas between improved property and a potential wildland fire where the combustibles have been removed or modified with the intent to: (1) protect life and property from wildfire, (2) reduce the potential for fire on improved property from spreading to wildland fuels, 
and (3) provide a safe working area for firefighters protecting life and improved property. All significant INEEL structures, systems, and components located at the wildland/facility interface ${ }^{1}$ would have a defensible space. These include buildings of value, parking lots, storage areas, high-value field equipment (such as drill rigs), and utility system components (such as transformers, substations, propane tanks, storm water injection wells, wastewater treatment facilities). One or more of the following methods can provide defensible space:

- Irrigating area perimeters, lay down yards, and other structures

- Paving or placing gravel over areas

- Mowing vegetation

- Blading with or without sterilization

- Prescribed fire.

In general, a defensible space of 30 -ft is adequate for most INEEL structures. Defensible spaces in excess of $30-\mathrm{ft}$ but not more than $100-\mathrm{ft}$ are required in situations where improved property is at greater risk (combustible construction material, heavy fuel loading upwind of structure, etc.). The INEEL would implement some level of defensible space in all of the proposed alternatives.

Wildland Fire Management Committee - The INEEL could establish_aA Wildland Fire Management Committee to-would provide recommendations to the DOE Idaho Operations Office (DOE-ID) manager for pre-fire and post-fire activities and to facilitate the implementation of those activities. The committee would consist of proponents of cultural resources, threatened and endangered $(T \& E)$ species, vegetation, wildlife, soils, watersheds, air, the Sagebrush Steppe Reserve, the NERP, National Environmental Policy Act (NEPA), Fire Marshall, Fire Department, GIS specialist and INEEL operations. Additional resource advisors could be added when specific technical advice is required or other resources are impacted. The committee would convene to develop recommendations for pre-fire, fire suppression, and post-fire activities related to the long-term management of vegetation to minimize fuel loading and fire potential at the INEEL.

The Wildland Fire Management Committee would support a resource advisory function during fire suppression activities to provide consultation to the on-scene commander and evaluate the suppression strategy. Tactical fire suppression decisions would be evaluated in the field for potential impacts to natural resources. This consultation would provide a mechanism for informal decisions regarding environmental impacts and minimize impacts to the extent feasible. A standardized mapping system that effectively identifies environmental resource areas of concern should-could be established to support onscene planning.

The Wildland Fire Management Committee would meet following large fires. If hazardous conditions exist after the fire (fugitive dust on roads, SCAs exposed, etc.), the committee would meet within 24 hours of the fire being declared "out" and develop a plan to mitigate hazardous conditions. If such conditions do not exist, the committee would meet within one week of the fire. The post-fire objectives of the committee include:

- Locating and stabilizing fugitive dust source areas that pose a direct threat to human health and safety, property, and critically important cultural and natural resources

- Preventing irreversible loss of natural and cultural resources, and the information they may provide

- Developing a restoration plan and a schedule

\footnotetext{
${ }^{1}$ Wildland/facility interfaces are management as traditional wildland/urban interfaces. They reflect a defined boundary between INEEL improved property and INEEL wildlands.
} 
- Conducting immediate post-fire reconnaissance for fire suppression impacts to natural and cultural resources, including species protected under the ESA

- Providing long-term monitoring recommendations.

The committee would provide the DOE-ID manager with recommendations to meet these objectives in the form of a plan. The plan would be presented to the manager or designated representative within 2 weeks of the fire for approval. Annual modifications to that plan may be required until restoration is complete. Activities in the plan could range from natural recovery (no action) to any of those described in the following alternatives (see Section 2.2). This planning effort would be limited to INEEL fires, and plans would be formulated as determined necessary by the committee, based on the significance of potential impacts.

\subsubsection{Fire Suppression Activities}

Staged Response Strategy - Staged response refers to a level of response needed to support a containment objective during the first burning period. During the early portions of the wildland fire season, when fire danger ratings are low to moderate, a single heavy wildland unit, supporting off-road water tender, and a chase vehicle is dispatched as an initial response. In general, fires that occur during these conditions are fought directly with water and/or foam lines applied to knock down flames. A wet line and cold-trailing operation with shovels is generally adequate to contain and extinguish the fire.

During the peak fire season, when fire danger ratings are high to extreme, a heightened response is implemented. A heightened initial response would include a minimum of two heavy wildland units, supporting water tender, supporting chase vehicle and the dispatching of a dozer or grader to the scene. Additional offsite resources are generally requested during the initial response. Fires that occur during these conditions have the potential to exhibit extreme fire behavior. An aggressive initial attack strategy is critical in achieving the early fire containment objective. Fires that initiate and remain in light fuels can be adequately contained with direct attack, with the use of wet lines and cold-trailing in many situations. Fires that encounter large sections of medium to heavy fuel loads generally require a combination of fire suppression tactics, often supported by aerial delivery of chemical retardant and/or water, to contain the fire. Those fires produce high flame lengths and high rates of flame spread and often result in large fire areas. Such fire behavior generally requires the construction of graded containment lines to support containment objectives. Aerial application of chemical retardant and/or water is recommended for initial control efforts for fires during these conditions, particularly where natural or manmade barriers are not present to prevent significant fire spread. The aggressive response strategy during peak fire conditions offers the greatest chance of minimizing the fire size and associated impacts.

Direct, Indirect, and Parallel Tactics - Direct attacks are made directly on the fire's edge or perimeter. The flames are knocked down by dirt or water and a follow-up containment line constructed by hand or with dozer/grader blades and generally treats the fire edge. In some situations, a containment line is constructed close to the fire's edge and the fuel between the containment line and the fire is burned out or the fire is allowed to burn to the containment line. Firefighters are placed directly at the fire's edge. Direct attack is limited to low intensity fires (flame lengths less than 4-ft) that allows firefighters to work safely close to the fire. Direct tactics are generally limited to fires burning in light fuels or fuels with high moisture content burning under light wind conditions. Direct tactics are most effective early in the fire season, when fuel loads are light and fire danger conditions are low to moderate.

Indirect tactics are made some distance from the fire. Indirect tactics include building a containment line some distance from the fire edge and burning the unburned fuel between the containment line and the fire edge. Indirect tactics take advantage of natural and manmade barriers as containment lines. Generally, indirect tactics are used on hot fires with flame lengths greater than 4-ft and high rates of spread or where 
direct tactics are not possible. Indirect tactics are often necessary to support containment of fires involving medium and heavy fuels and high to extreme fire danger conditions.

Parallel tactics are made by constructing a containment line parallel to, but further from, the fire edge than in direct tactics. Parallel tactics may shorten containment line construction by cutting across unburned fingers. In many cases, the fuel between the containment line and the fire edge must be burned in conjunction with containment line construction to effectively check the fire.

Minimum Impact Suppression Tactics - MIST emphasizes suppressing a wildland fire with the least impact on the land. Actual fire conditions and good judgment dictate actions taken. Firefighter and public safety would not be compromised nor would the overall objective of property protection and early containment. Appropriate actions are taken based on the fire's potential to spread and cause damage to resources, including mature sagebrush, at the particular location of the fire (see inset).

\subsubsection{Post-Fire Activities}

Dust Suppression - The INEEL could use chemical and physical methods such as soil tackifier, surfactants, or mulch to minimize fugitive dust following wildland fires, including dust from SCAs. In addition, the INEEL may use other methods to control dust, such as water cannons around facilities and snow fences upwind of facilities.

Site Restoration - The INEEL could implement the following site restoration guidelines. The Wildland Fire Management Committee (see below) would

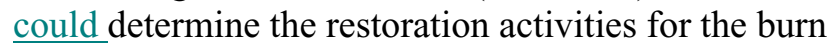
area.

- Inventory the burned area for fire and fire suppression impacts to resources

- Fill in deep and wide containment lines and cup trenches and recontour containment lines

- Waterbar newly created roads or containment lines, as necessary, to prevent erosion, or use woody material to act as sediment dams

- Scatter in a natural pattern large-size brush or trees cut during containment line construction

- Install sediment controls to prevent sedimentation of waterways and wastewater treatment basins

- Remove debris and sediment from waterways (check annually)

- Restore helicopter landing sites, equipment staging sites, and similarly disturbed areas

- Control all noxious weeds

- Evaluate necessity to revegetate all or portions of the burn or areas impacted by fire suppression activities using native species by broadcast seeding, drilling, containerized stock or wildings

- Use seeds, containerized stock, or wildings from local collections of site-adapted stock 
- Base decision to revegetate en-an area on inventories of affected areas for natural recovery that approaches pre-fire densities of native species

- Use GIS to map all areas receiving restoration treatments

- Prohibit off-road vehicles from using burned area

- Continue monitoring until restoration is complete

- Remove all signs of human activity (such as plastic flagging, litter, spills)

- Conduct surveys of affected areas, associated with burn suppression activities, such as containment lines and equipment staging areas, and to assess damage to cultural and natural resources

- Prepare and submit an environmental checklist, before any site restoration activities, to document environmental impacts from fire suppression activities and provide feedback to align potential impacts with those analyzed in this environmental assessment.

In addition, the INEEL would establish a Wildland Fire Management Committee to provide recommendations to the DOE Idaho Operations Office (DOE-ID) manager for pre- and post-fire activities and to facilitate the implementation of those activities (see Section 2.1.1).

\subsection{Alternatives}

Table 2-1 summarizes and compares the pre-fire, fire suppression, and post-fire wildland fire management activities across all four alternatives. A short description of each alternative is given below, along with major differences between alternatives.

\subsubsection{Alternative 1 - Maximum Fire Protection Approach}

Alternative 1 would meet the INEEL Infrastructure management goals related to minimizing the zulnerability of INEEL personnel and property to wildland fire damage by minimizing fire size and duration. In addition, this alternative would best achieve Infrastructures' goals to minimize or eliminate eontamination spread should a wildland fire threaten an SCA.

Alternative 1, the Maximum Fire Protection Approach includes the implementation of full pre-fire, fire suppression and post-fire activities. Elements of this alternative focus on creating firebreaks along improved and unimproved roads, around facility perimeters and power poles, and creating defensible space around SCAs. Once a fire begins, the INEEL Fire Department would use wildland units, aerial support, and other means available through agreements with state and federal agencies to aggressively fight the fires. Following fires, the INEEL would focus efforts to mitigate impacts caused by the emergency response actions through cultural and wildlife/habitat surveys and restoration activities, such as replanting with native species. This alternative would protect all SCAs. This alternative includes the creation of a Wildland Fire Management Committee to provide recommendations on wildland fire management to DOE-ID. This alternative would not use MIST (see Section 2.1).

\subsubsection{Alternative 2 - Balanced Fire Protection Approach}

Alternative 2 would meet most of the INEEL Infrastructure management goals related to minimizing the zulnerability of the INEEL personnel and property to wildland fire damage. Fire size and duration would be slightly greater than with Alternative 1.

Alternative 2, the Balanced Fire Protection Approach includes pre-fire, fire suppression and post-fire activities. In developing this approach, DOE considered the needs of protecting infrastructure and the natural resources of the INEEL. The Balanced Fire Protection Approach differs from the Traditional Fire Protection Approach (see Section 2.2.4), by taking into consideration the long-term management of native vegetation to minimize fuel loading and fire potential at the INEEL. This alternative includes the creation 
of a Wildland Fire Management Committee to provide recommendations on wildland fire management to DOE-ID. As in Alternative 1, the Fire Department would aggressively fight fires; however, they would use MIST when considering initial attack (as feasible) and mop-up tactics to minimize impacts from fire suppression activities (see Section 2.1).

\subsubsection{Alternative 3 - Protect Infrastructure and Personnel Safety Approach}

Alternative 3 would not meet most of the INEEL Infrastructure management goals. While the goals for this alternative would protect infrastructure and provide Personnel safety, it would not minimize damage to sagebrush stands. Allowing wildland fires to burn would not meet the objective to minimize the potential to impact adjacent public and private lands.

Alternative 3, the Protect Infrastructure and Personnel Safety Approach, includes only those activities identified as necessary to protect primary INEEL facilities including those pre-fire activities judged necessary to provide a safe space for firefighters within the site areas. The Fire Department would take no actions to protect SCAs, National Oceanic and Atmospheric Administration (NOAA) stations, or similar sites within the INEEL boundaries. The Fire Department would only fight fires that threatened primary INEEL facilities, letting others burn. This alternative would not use MIST in conjunction with fire suppression activities (see Section 2.1).

\subsubsection{Alternative 4 - No Action or Traditional Fire Protection Approach}

Alternative 4 would meet most of the INEEL Infrastructure management goals. However, this alternative would not meet the specific objective related to restoration of disturbed areas by pre-fire, fire suppression and post fire activities.

Alternative 4, the No Action or Traditional Fire Protection Approach would continue INEEL's traditional pre-fire, fire suppression and post-fire activities. That is, the INEEL would continue to prepare for fires by doing an annual assessment of fuel loads and mowing vegetation or blading areas that represent a risk to infrastructure or people. In addition, once a fire starts, the INEEL would use similar tactics as in the Maximum Fire Protection Approach alternative to extinguish the fire. The INEEL would not mitigate impacts to the environment from emergency response activities, such as soil disturbance or vegetation removal. The Traditional Fire Protection Approach would not include aggressive pre-fire activities such as mowing vegetation along unimproved roads, but would continue to fight fires aggressively (see Section 2.1). 


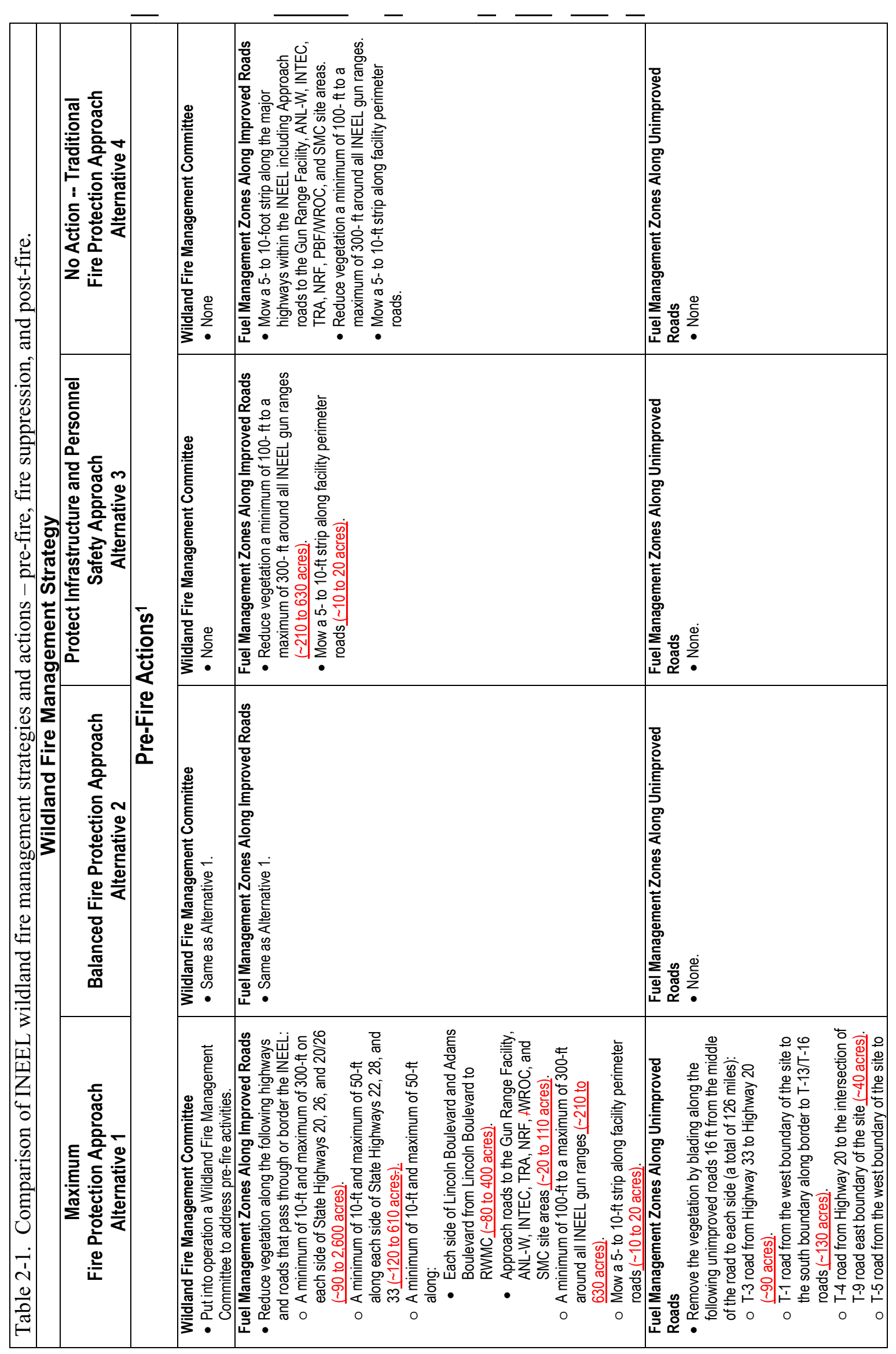

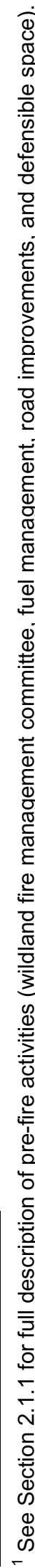




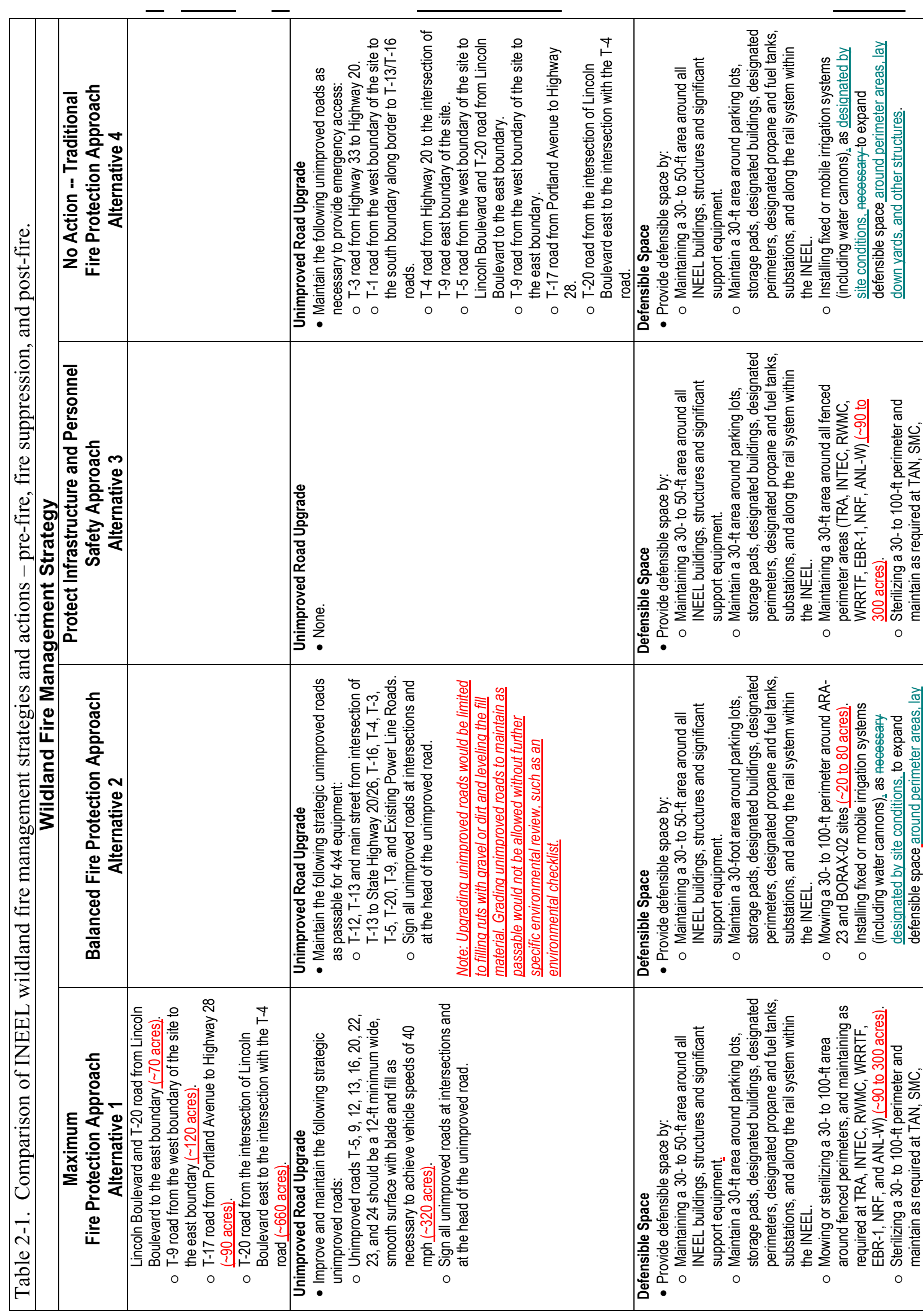




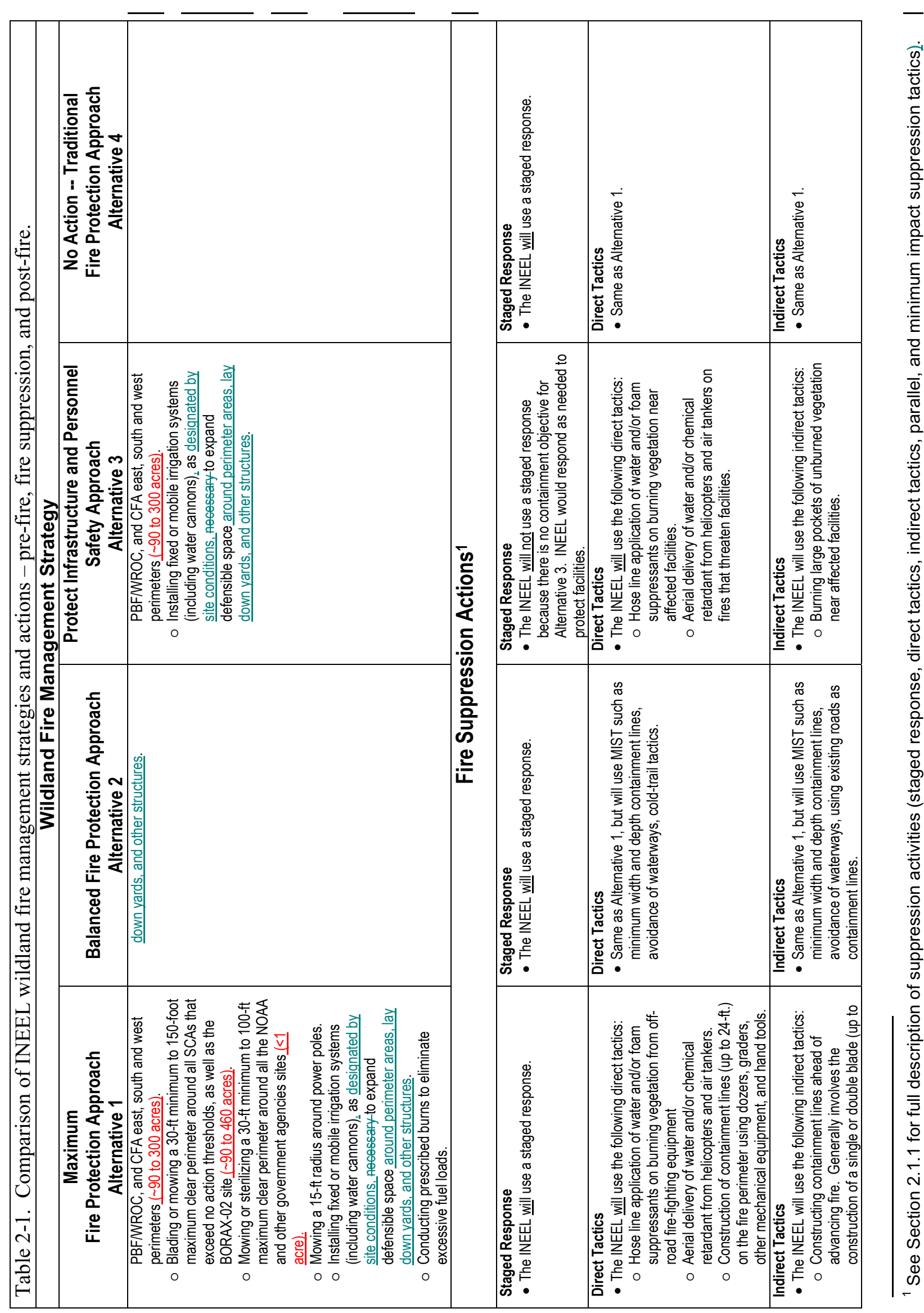




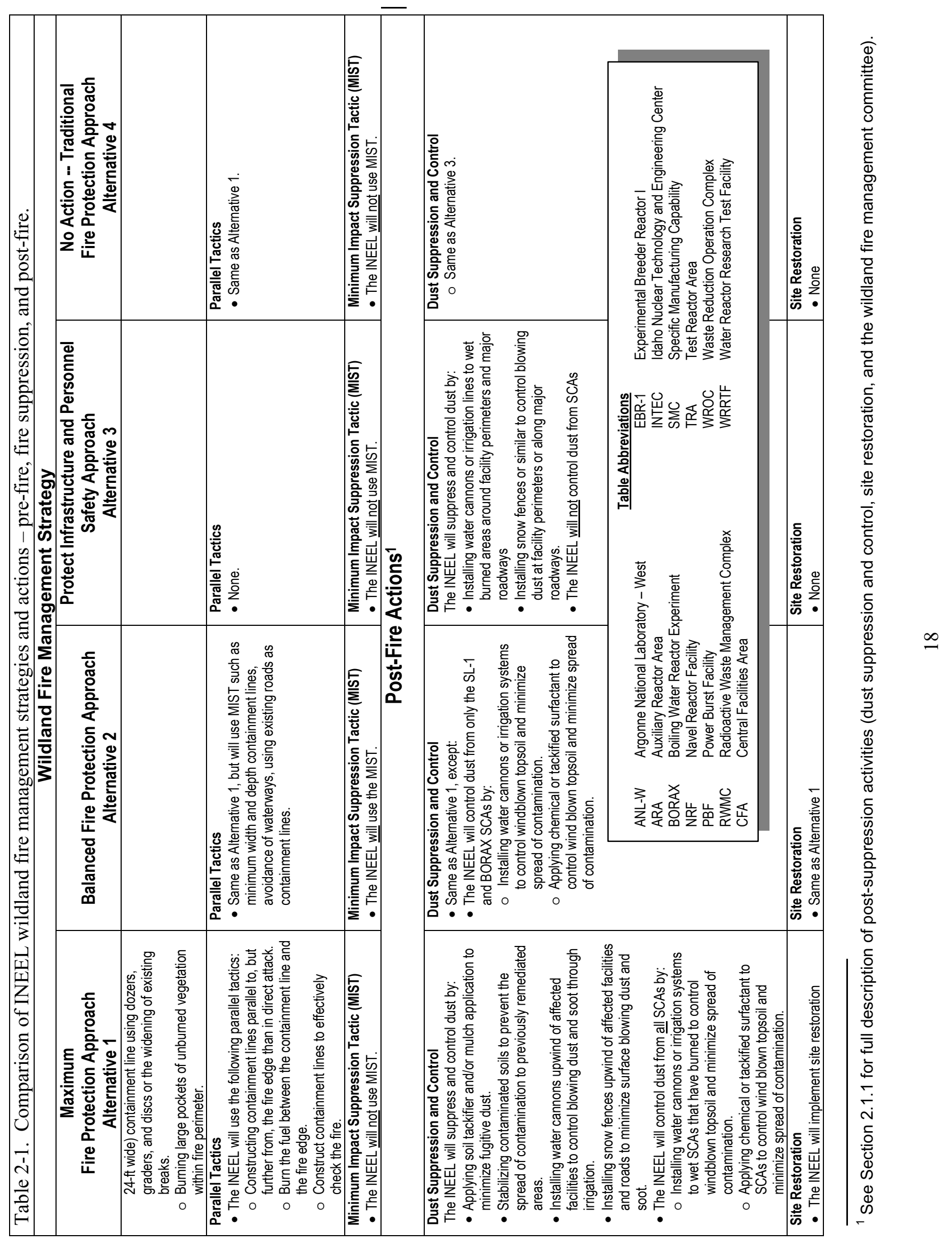




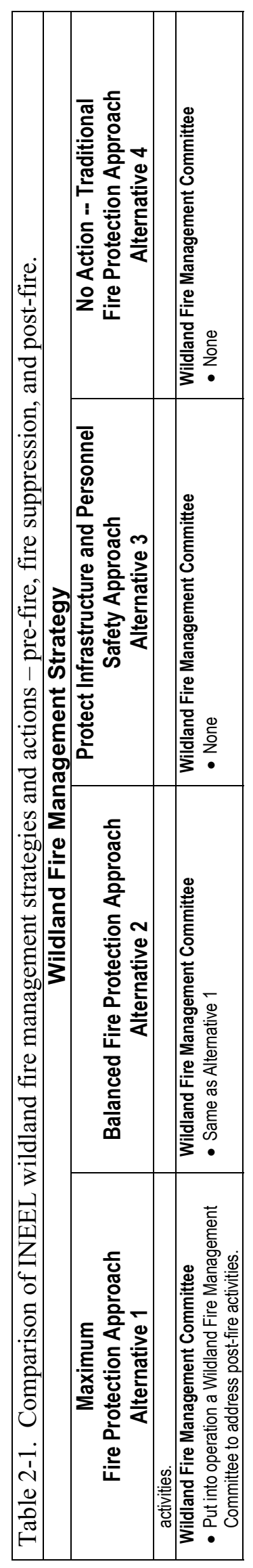




\section{AFFECTED ENVIRONMENT}

\subsection{General Site and Facility Description}

The INEEL is an 890 square mile DOE facility located in southeastern Idaho (Figure 3-1). The DOE Programmatic Spent Nuclear Fuel Management and Idaho National Engineering Laboratory Environmental Restoration and Waste Management Programs Final Environmental Impact Statement, DOE/EIS-0203-F, April 1995 (FEIS) (DOE 1995a) describes the physical and biological environment of the region, in general, and the INEEL in particular. The following sections describe specific information for air, water, biological, and cultural/historical resources, as it relates to wildland fires on the INEEL.

The INEEL consists of several facility areas situated on an expanse of otherwise undeveloped, cool-desert terrain. Buildings and structures at the INEEL are clustered within those site areas, which are typically less than a few square miles in size and separated from each other by miles of primarily undeveloped land (Figure 3-1). DOE controls all land within the INEEL. The INEEL occupies portions of five Idaho counties: Butte, Bingham, Bonneville, Clark, and Jefferson.

Population centers in the region include large cities $(>10,000)$ such as Idaho Falls, Pocatello, and Blackfoot located to the East and South and several smaller cities $(<10,000)$ located around the site such as Arco, Howe, and Atomic City. Yellowstone and Grand Teton National Parks and the City of Jackson

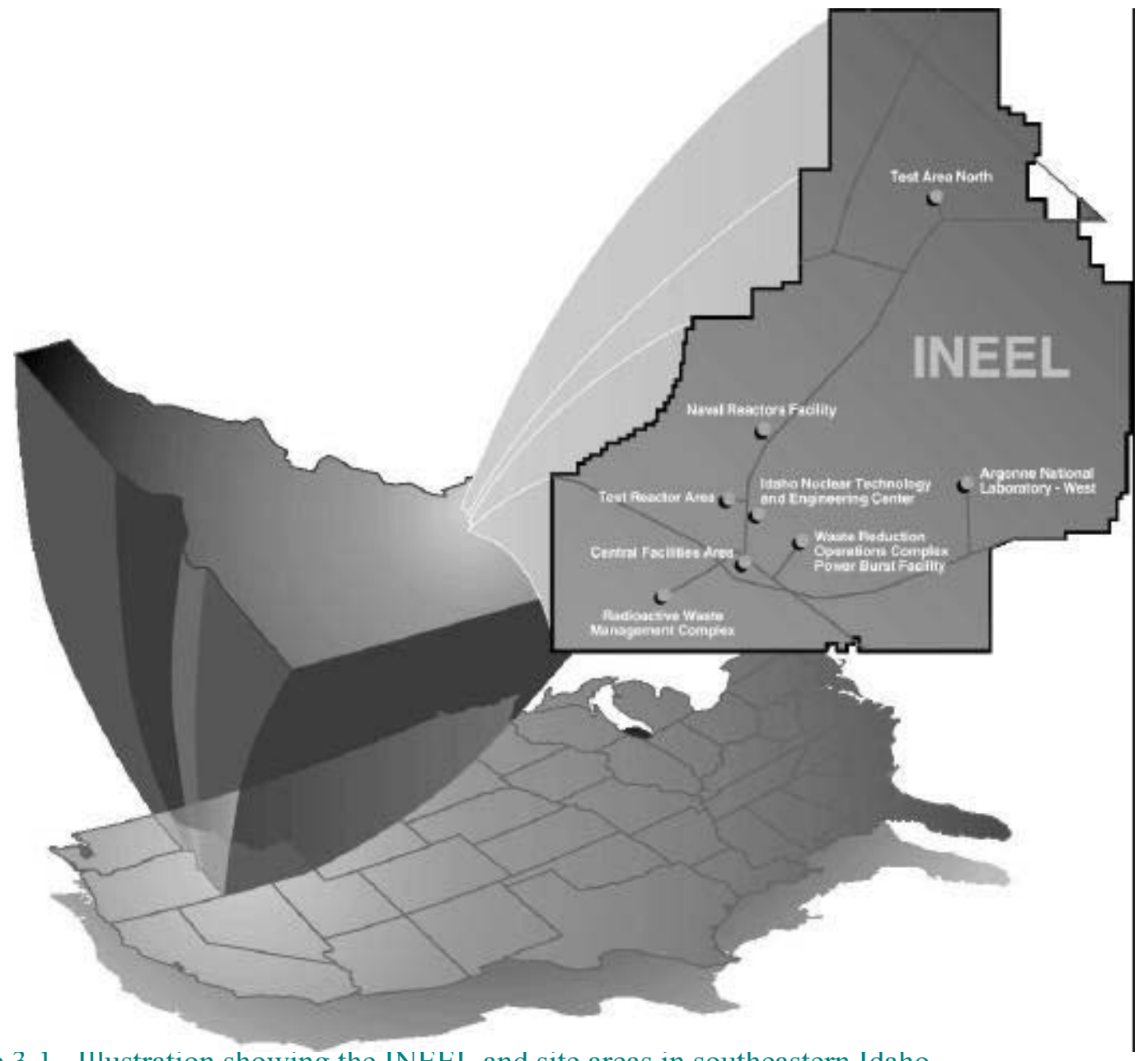

Figure 3-1. Illustration showing the INEEL and site areas in southeastern Idaho. 
Hole, Wyoming are located less than 60 miles to the northeast. There are no permanent residents on the INEEL.

\subsection{Air Resources}

The area surrounding the INEEL is classified as a Prevention of Significant Deterioration (PSD)-Class II Area, designated under the Clean Air Act (CAA) as an area with reasonable or moderately good air quality while still allowing moderate industrial growth. About 12 miles west of the INEEL is Craters of the Moon National Monument and Wilderness Area. The Wilderness is classified as a PSD Class I Area. Planned activities at the INEEL must not negatively impact the air quality in this Class I Area.

Local mountains and valleys influence wind patterns on the INEEL. The prevailing westerly winds in the area are channeled within the Eastern Snake River Plain into west-southwest and southwest flows. These winds are strongest in the spring. At night, winds may reverse direction due to down-slope flows from the mountains to the north of the INEEL. At Test Area North (TAN) (northern portion of the site); the closer proximity of the mountains causes wind patterns to be somewhat different than at the other sites.

A significant cause of fires on and around the INEEL is lightning strikes during thunderstorms. Lighting caused nine of the 14 fires on the INEEL during CY 2000 (E. Gosswiller, pers. com.). The INEEL experiences an average of 2-3 thunderstorm days ${ }^{1}$ each of the summer months from June through August. Several individual thunderstorms may occur during each of those thunderstorm days (Clawson et al., 1989).

The INEEL routinely monitors air quality using a network of air monitors. These monitors collect samples for measurement of particulate matter (both total suspended particulate and PM10), radioactivity, and other air pollutants.

Wildfires impact air quality in several ways through direct and indirect emissions of:

- Smoke during fires

- Dust from denuded landscapes following fires

- Dust from fire prevention and firefighting (such as creating defensible space and cutting containment lines).

Wind erosion can be significant following a fire. For instance, the weekly concentrations following a wildland fire (as measured at Test Reactor Area [TRA]) can be as high as 500 micrograms of particulate per cubic meter of air sampled $\left(\mu \mathrm{g} / \mathrm{m}^{3}\right)$, which is significantly higher than the typical average weekly concentration of less than $25 \mu \mathrm{g} / \mathrm{m}^{3}$.

Following the fire August 16, 1995, the INEEL conducted soil erosion monitoring at four burned locations on the INEEL. Results of the monitoring revealed that one location gained soil, and three locations lost soil. Most of the

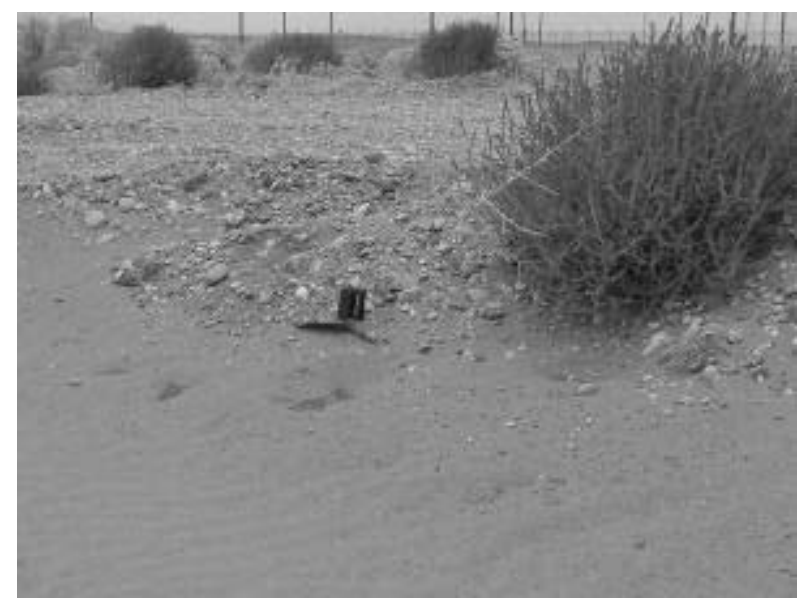

Figure 3-2. Windblown sediment after a fire event.

\footnotetext{
${ }^{1}$ A thunderstorm day is defined by National Weather Service as a day on which thunder is heard at a given observing station. Lightning does not have to be seen, and rainfall and/or hail is not required.
} 
soil was transported by the wind (Figure 3-2). The maximum measured erosion rate was 239 tons of soil per acre per year (Olson 1996). Erosion rates of 200 tons/acre/year are typical for measurements conducted by the BLM on burned land in and around the INEEL and are significant when compared to the typical slight deposition erosion rates for unburned land on the INEEL (Jeppesen 2001). Erosion rates of 5 tons/acre/year or more are considered detrimental to farmland. Erosion rates detrimental to rangeland have not been established, but are likely less than 5 tons/acre/year.

Wildfires burning through SCAs can have additional impacts. SCAs were initially identified and posted to provide interim control of the areas until they could be evaluated and, if necessary, cleaned up under the Comprehensive Environmental Response Compensation and Liability Act (CERCLA). Because most of these areas are covered with burnable vegetation, wildfires present the potential for releasing radionuclide contamination to the air. These releases could occur due to any or all of the following:

- Burning contaminated vegetation (contaminated through root uptake of radionuclides),

- Disturbing, thereby resuspending, contaminated soil with firefighting vehicles, or

- Resuspension of contaminated soil by a windstorm following a burn.

Lipp (1994) cataloged 35 SCAs on the INEEL. Staley et al. (2001) examined these 35 sites, as well as one large but lightly contaminated CERCLA site in terms of potential for fire and subsequent contaminated dust release, and calculated both onsite and offsite doses from exposures to fire smoke and dust. Many of the SCAs were eliminated from detailed examination based on several criteria:

- Areas cleaned up or covered

- Areas inside facility fences and therefore protected from burning

- Areas with contamination levels below thresholds levels.

Of the initial 35 SCAs, six SCAs and a large CERCLA site (CPP-95) were retained for detailed analysis (Table 3-1). It should be noted that the six SCA's account for $0.05 \%$ of the total INEEL land area; $0.4 \%$ if CPP-95 (the large CERCLA site with Cesium contamination below the CERCLA no-no-action threshold) is added. In this EA, "SCA" refers collectively to these seven areas. In addition, the INEEL is concerned that radioactive contamination from wildland fires may contaminate the clean caps of two sites: SL-1 and BORAX-02.

\subsection{Water Resources}

Hydrology on the INEEL includes water from three streams (Figure 3-3) and from local runoff caused by snowmelt. The three streams are the Big Lost River, Birch Creek, and the Little Lost River. On the INEEL, the Big Lost River is either diverted southward to the spreading areas or flows northward, through a wetland (Big Lost Sinks), to three playas. Since 1965, there has been several periods of continuous stream flowflow; the longest, a during a 5-year and 9-year period between May 1968 and May 1977 interrupted by periods of no flowand annual volumes have exceeded 300,000 acre-feet. The longest period of continuous flow was a 9-year period between May 1968 and May 1977. Typically, Birch Creek flows to the INEEL during the non-irrigation season and terminates on an alluvial fan. The Little Lost River is often depleted by irrigation diversions and infiltration in the Little Lost River sinks, and infrequently flows onto the INEEL. All three streams receive water from mountain watersheds located to the north and northwest of the INEEL. Water either evaporates or infiltrates because the INEEL is within a topographic depression with no outlet. The Snake River Plain Aquifer underlying the INEEL is recharged by infiltration of surface water and is used extensively for drinking, irrigation, and aquaculture. The INEEL pumps water from the aquifer to use for operations, drinking, and lawn watering. During 2000 , the INEEL pumped 3500 acre-feet of water, about $10 \%$ of the INEEL's federally reserved water 
Table 3-1. SCAs and soil contamination levels modeled for fire and post-fire releases.

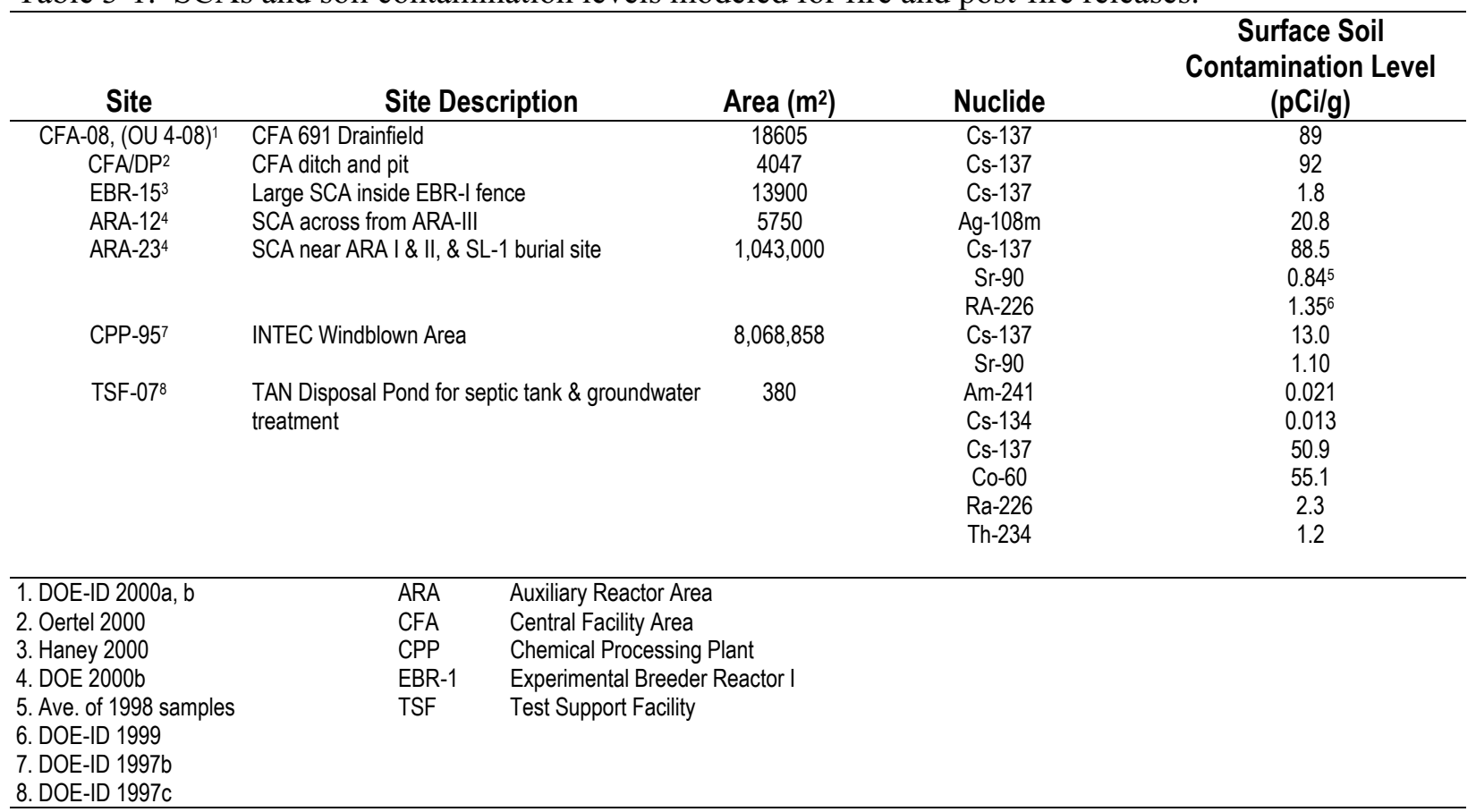

right. The aquifer's economic and environmental significance has been recognized by the U.S. Environmental Protection Agency (EPA) designation as a sole source aquifer.

The average annual precipitation is 8.70 inches at the Central Facilities Area (CFA) and 7.85 inches at TAN (Clawson et al. 1989). Peak rainfall occurs during May and June, but high infiltration rates preclude significant accumulation of surface waters. The water content of snow contributes between one-quarter and onethird of the total yearly precipitation. Local snowmelt has necessitated the construction of surface water management features, such as deep injection wells at TAN, CFA, and Power Burst Facility (PBF); dikes and retention basins at TAN; a water control structure at Argonne

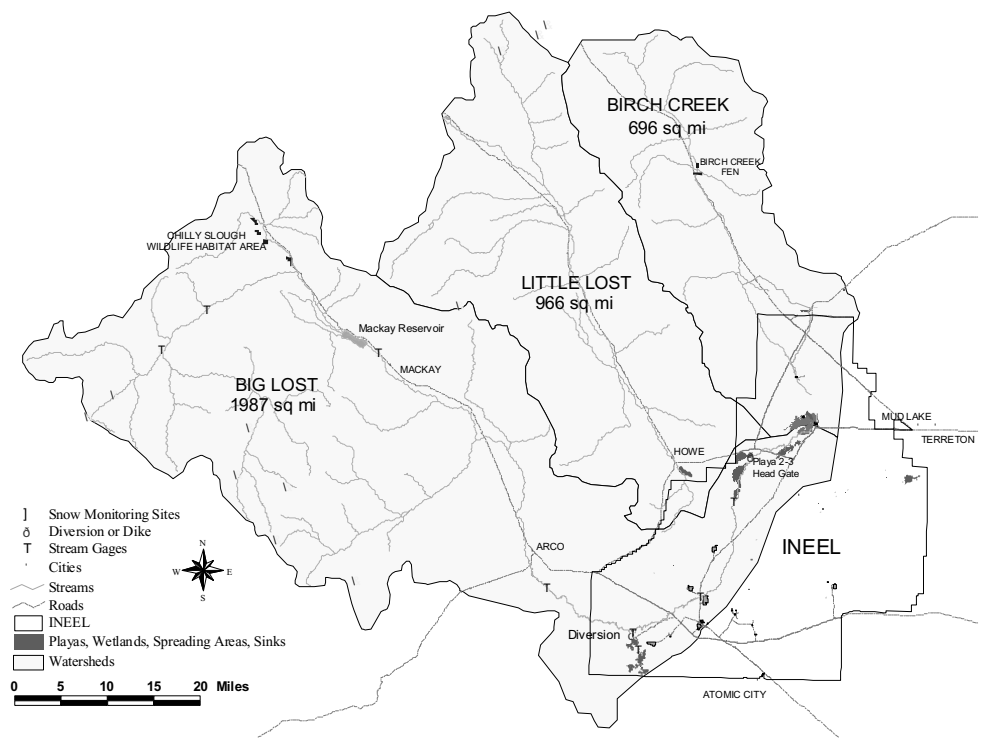

Figure 3-3. Illustration showing the surface water on the INEEL. National Laboratory - West (ANL-W); and several drainage channels. Localized flooding occurred at Radioactive Waste Management Complex (RWMC); so, a flood control channel was constructed to covey snowmelt to the Big Lost River. Ice jams in the Big Lost River threatened flooding of TRA and Idaho Nuclear Technology and Engineering Center (INTEC) and necessitated construction of a small diversion dam. 


\subsection{Wildlife/Habitat Resources}

The INEEL contains the largest remnant of undeveloped, ungrazed sagebrush steppe ecosystem in the Intermountain West (DOE-ID 1997a). That ecosystem has been identified as critically endangered with less than two percent of its original vegetation remaining (Noss et al. 1995, Saab and Rich 1997).

Because it contains the largest remnant of this ecosystem type, the INEEL is an internationally significant ecological resource. The natural vegetation of the INEEL consists of a shrub overstory with a forbs and grass understory. The most common shrub is Wyoming big sagebrush. Basin big sage may dominate or co-dominate with Wyoming big sage in areas with deep or sandy soils (Shumar and Anderson 1986). Green rabbitbrush is the next most abundant shrub. Other common shrubs include winterfat, spiney hopsage, gray horsebrush, gray rabbitbrush, and prickly phlox (Anderson et al. 1996).

The shrub understory consists of a variety of grasses and forbs. The most common native grasses include thickspiked wheatgrass, Indian ricegrass, bottlebrush squirreltail, needle-and-thread grass, Nevada bluegrass, and bluebunch wheatgrass. Common native forbs include tapertip hawksbeard, Hood's phlox, hoary false yarrow, paintbrush, globe-mallow, buckwheat, lupine, milkvetches and mustards (Anderson et al. 1996).

Anderson et al. (1996) broadly described ten vegetation classes and plant communities that occur on the INEEL. Those communities do not represent homogeneous community types, but integrate communities that share dominant species and are more similar to each other than to communities represented by other vegetation classes. Sagebrush steppe is the dominant plant community or vegetation type on the INEEL. Other community types include: juniper woodlands, grasslands, low shrubs on lava, sagebrushrabbitbrush, sagebrush-winterfat, salt desert shrub, wetlands. In addition, playas, bare ground or disturbed areas, and lava are also considered community types.

Several large fires have occurred on the INEEL over the past decade burning over 130,000 acres. A study conducted by Patrick and Anderson (1999) indicated that if healthy populations of native species are present on a site when wildfire occurs, the native community can recover and resist invasion by exotic species. Wyoming big sagebrush can take 30 years or more after a fire to become re-established (Watts and Wambolt 1996, Wambolt et al. 2001). Estimates of fire return intervals for sagebrush steppe range from about 20 to more than 100 years (Houston 1973, Wright et al. 1979, Wright and Bailey 1982). Because Wyoming big sagebrush is generally considered to be the slowest of the sagebrush species to return following fire, it is likely that fire return intervals on the INEEL are at the upper end of that range.

The introduction of cheatgrass and other exotic annual plant species has altered the effects of fire in the sagebrush steppe ecosystem. Wildfire in areas where the understory is dominated by cheatgrass results in the conversion of native sagebrush steppe to annual grasslands (Hosten and West 1994). Dense stands of cured cheatgrass are highly flammable and can result in an increased fire frequency of three to five years (Young and Evans 1978, Wright and Bailey 1982). The increased fire frequency greatly limits, if not prohibits the ability of native species to recover.

Long-term trend plots on the INEEL showed a rapid invasion of cheatgrass between 1965 and 1975, even in areas that had not been grazed for 20 or more years (Anderson and Inouye 2001). Even though cheatgrass can be found on much of the INEEL, its abundance is limited. Although it does not presently appear to be a significant threat on the INEEL, cheatgrass has become dominant in isolated patches in areas with shallow or coarser soils. Probably the most important risk factors for cheatgrass dominance on the INEEL are surface disturbance and loss of native perennial plants. Anderson and Inouye (2001) reported that native plant cover inhibited cheatgrass cover. Cheatgrass is seen at greatest densities on sites where the soil has been disturbed to the extent that native perennial plants have been removed. 
Unlike other parts of the West, wildfire on the INEEL does not necessarily condemn the area to cheatgrass domination (Patrick and Anderson 1999).

Because soil disturbance increases the likelihood for invasion by non-native plants more that than just fire alone, a vegetation survey was conducted on containment lines from previous fires and firebreaks constructed before the 2001 fire season began. Vegetation surveys were conducted to obtain information on the response of plant species to fire and soil disturbance (See Appendix A). Although no plant species listed under the Federal ESA were located, exotic invasive species were identified in several areas.

A total of 219 vertebrate species have been recorded on the INEEL (Reynolds et al. 1986). Several vertebrate species present on the INEEL are considered sagebrush-obligate species, meaning that they rely upon sagebrush for survival. Among others, those species include: sage sparrow, Brewer's sparrow, northern sagebrush lizard, sage grouse, and pygmy rabbit.

Fish species present in the Big Lost River on the INEEL include rainbow trout, brook trout, mountain whitefish, sculpin and kokanee salmon (Overton 1977).

The ESA provides Federal protection for certain species of plants and animals and their critical habitats, and authorizes the Secretary of the Interior to develop and implement recovery plans for each listed species. Species and/or habitat that are currently listed as Endangered, Threatened, a Species of Concern, or Candidate Species ${ }^{1}$ and may occur on the INEEL include: gray wolf, bald eagle, Ute ladies' tresses, yellow billed cuckoo, slender moonwort,long-eared myotis, small-footed myotis, Townsend's big-eared bat, pygmy rabbit, Merriam's shrew, greater sage-grouse, long-billed curlew, ferruginous hawk, northern sagebrush lizard, painted milkvetch, and loggerhead shrike. Status of these species is shown in Table 3-2). The FWS has indicated ${ }^{z}$ concerns about several plants and animals that do or may occur on the INEEL. Although these species have no status under the ESA, FWS is concerned about their population status and threats to their long term viability. In context with ecosystem-level management, the FWS suggests that these species and their habitats be considered in project planning and review.

\footnotetext{
${ }^{1}$ Endangered, Threatened and Candidate are special terms under the ESA that list the status of plant or animal species. Species of Concern is an informal term that refers to species whose conservation status may be of concern but do not receive protection under the ESA. Designation as a species of concern does not mean a species will eventually be proposed for listing under the ESA.

${ }^{z}$ Letter from Snake River Basin Office, USFWS to Roger Blew, September 1, 2001; Department of Energy, Idaho National Engineering and Environmental Laboratory Species List Update; 1-4-01-SP-1118/Updates \#1-4-01SP826/506.0000.
} 
The INEEL is also a NERP. DOE established the NERP program in the early 1970s and the Idaho NERP was chartered in 1975. The primary objectives for research on the NERPs are to develop methods for assessing the environmental impact of energy development activities, to develop methods for predicting those impacts, and to develop methods for mitigating those impacts. Included in the NERP's research activities is the long-term vegetation transect. These transects were established in 1950 and have been read on a regular basis since then. The data from these transects represents one of the longest-term rangeland vegetation databases in the western United States. A portion of the INEEL has been designated as the Sagebrush Steppe Ecosystem Reserve that has a mission efto eonducting provide research opportunities en-and preserving-preserve sagebrush steppe habitat (see Section 1.3).

\subsection{Cultural/Historical Resources}

The INEEL has been a federal reservation with restricted public access since the early 1940s. Due to both its continuous access restriction and geographic remoteness, the rich and varied cultural resource record within the INEEL boundary is remarkably well preserved. This includes fossil localities that provide an important paleontological context for the region and the many prehistoric archaeological sites preserved within it. The latter sites, including campsites, lithic workshops, cairns, and hunting blinds, among others, are also an important part of the INEEL inventory because they provide information about the activities of aboriginal hunting and gathering groups who inhabited the area for about 12,000 years. In addition, archaeological sites, pictographs, caves and many other features of the INEEL landscape are also important to contemporary Native American groups for historic, religious, and traditional reasons. Historic sites, including the abandoned town of Pioneer/Powell, a northern spur of the Oregon Trail known as Goodale's Cutoff, many small homesteads, irrigation canals, sheep and cattle camps, and stage and wagon trails, document the use of the area during the late 1800s and early 1900s. Finally, many

Table 3-2. Federal and state listed threatened, endangered, candidate or sensitive species ocurring or potentially occurring on the INEEL. .

\begin{tabular}{|c|c|c|c|}
\hline Common Name & Scientific Name & Federal (FWS) status ${ }^{2}$ & State (IDFG) Status ${ }^{2}$ \\
\hline Painted milkvetch & Astragalus ceramicus var. apus & SC & \\
\hline Slender moonwort & Botrychium lineare & C & \\
\hline Bald eagle & Haliaeetus leucocephalus & $\mathrm{T}$ & $\mathrm{T}$ \\
\hline Ferruginous hawk & Buteo regalis & SC & \\
\hline Long-billed curlew & Numenius americanus & SC & \\
\hline Loggerhead shrike & Lanius ludovicianus & & SC \\
\hline Gray wolf & Canis lupus & $\mathrm{XN}$ & $\mathrm{XN}$ \\
\hline Sage grouse & Centrocercus urophasianus & SC & SC \\
\hline Pygmy rabbit & Brachylagus idahoensis & SC & SC \\
\hline Townsend's western big-eared bat & Corynorhinus townsendii & SC & SC \\
\hline Merriam's shrew & Sorex merriami & SC & \\
\hline Long-eared myotis & Myotis evotis & SC & \\
\hline Small-footed myotis & Myotis ciliolabrum & SC & \\
\hline Northern sagebrush lizard & Sceloporus graciosus graciosus & SC & \\
\hline
\end{tabular}

scientific and technical facilities inside the INEEL boundaries have preserved important information on the historic development of nuclear science in America (DOE-ID 1995b).

The diversity and uniqueness of INEEL cultural resources became known when sporadic archaeological investigations began on the INEEL in the late 1950s and continued to increase as a result of issuance of Section 106 of the National Historic Preservation Act (NHPA), and the creation of the INEEL CRMO in 1989 (DOE 1995b) 
While only $7-8 \%$ of the total 890 -square mile reserve has been surveyed (about 42,900 acres out of 570,000 ), this has resulted in nearly 2,000 archaeological locations and over 200 historic buildings being identified to date. A preliminary predictive model suggests that there may be as many as 75,000 additional prehistoric archaeological sites as yet undiscovered within the boundaries of the INEEL and many more historic sites, structures and artifacts are known to exist from the post-contact period, Euro American westward expansion and the subsequent post-1940s federal activities (Arrowrock Group Inc. 1998, Ringe 1995).

Geographically, the INEEL is included within a large territory once inhabited by, and still of importance to, the Shoshone-Bannock Tribes. To the Shoshone-Bannock people, cultural resources include not only archaeological sites that may be affiliated with their history, but also many kinds of natural resources such as traditionally used plants and animals. Finally, features of the natural landscape such as buttes, rivers, and caves are known to have particular significance to the Tribes

Beginning in 1995, INEEL CRMO personnel have-randomly documented adverse effects to cultural resources on the INEEL as the result of fire suppression activities associated with numerous wildland fires. In the fall of 2001, CRMO personnel surveyed approximately 128 acres associated with the Middle Butte Burn (July 2001), locating eight (8) cultural resource sites. All eight sites (six prehistoric lithic scatters, one prehistoric isolate, and one historic WWII military site) exhibited damage from containment lines and off-road vehicular traffic. Additionally, reconnaissance investigations were conducted in other areas known to possess highly sensitive and significant archaeological resources and recently impacted by fire suppression activity within the past few years. Aviator's Cave is arguably one of the most important archaeological locations on the INEEL. It is also considered by the Shoshone-Bannock Tribes to be an important cultural location. As a result of the Argonne burn of 1999, containment lines were constructed within 30-meters of the site and significant vehicular traffic on the site resulted in severe churning of surface artifacts, yielding diminished confidence levels for contextual information.

Reconnaissance was also conducted at various locations along the Big Lost River, south of Highway 20. This area is also extremely sensitive archaeologically and a number of instances were noted where containment lines and off-road vehicular traffic resulted in damage to cultural resources. These findings, supported by past observations, indicate that containment line and off-road vehicular traffic are the most significant causal factors for damage to cultural resources. Containment lines have bisected archaeological sites, churning under portions of them thus destroying contextual information. Wind blown sediments directly resulting from the lack of vegetation within the containment lines and adjacent lands has covered and obscured artifact distribution, and cultural material has been moved out of context due to water erosion and rilling originating in the containment lines.

Containment lines, along with new roads for staging purposes, have resulted in increased accessibility to significant and sensitive cultural resources on the INEEL such as Aviator's Cave. Removal of vegetative cover also makes cultural resources more visible, thereby increasing the potential for unlawful collection. The CRMO staff have recorded tire tracks plus debris from trespass. Other activities that have the potential to adversely affect cultural resources include, but are not limited to, mowing vegetation, blading roads or other areas, or grubbing and removal of vegetation by mechanical means including controlled burns, or firebreak emplacement.

\subsection{Areas of Previous Wildland Fire Response Impacts}

Previous wildland fire emergency response actions have historically and in the recent past (since 1994), affected parts of the INEEL. Figure A-4 (Appendix A) shows the location of firebreaks and containment lines from recent emergency response actions. These actions include many of the pre-fire and fire 
suppression activities such as blading roads, creating containment lines, and clearing vegetation (Figure 3-4 and Figure 3-5). The INEEL has not actively or successfully mitigated or restored most of those areas. Old containment lines surrounding many of the old wildfires are characterized by bare soil or are covered with weeds, including non-native vegetation. In addition, the biological and cultural resources located in those areas have likely been adversely impacted (see Sections 3.3, 3.4 and 3.5). Further, soildisturbing activities have likely increased the potential for soil erosion and subsequent sediment releases to the Big Lost River and Birch Creek.

Those areas now represent part of the affected environment. However, there is still a need to identify and restore those areas to prevent further impacts.

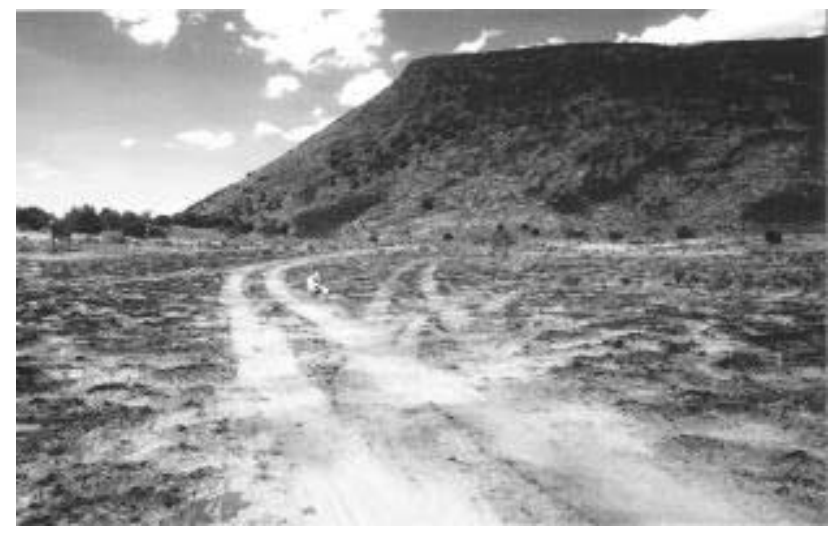

Figure 3-4. Example of previous disturbance.

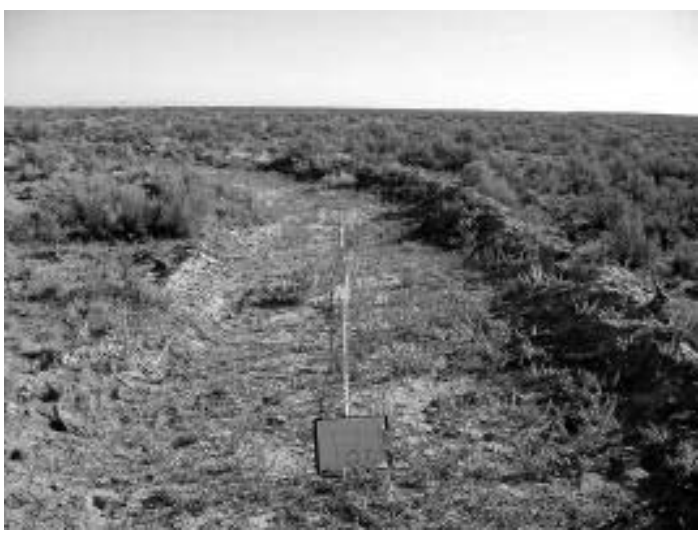

Figure 3-5. Containment line showing larger soil "ricks" and little recovery of native perennial vegetation. 


\section{ENVIRONMENTAL CONSEQUENCES}

The nature of wildland fires and their unpredictability makes it difficult to assess the potential impacts of the fires themselves or the emergency responses to those fires before they occur. For instance, the impacts of a proposed new road are easily determined by evaluating the disturbance of flora, fauna or cultural resources along the route of the proposed road. Direct impacts occur from a simple cause and effect relationship such as loss of small mammals that could not escape a wildland fire or the loss of a historical structure from wildland fire. Indirect impacts occur from secondary or higher-order relationships that act through intermediate sets of cause and effect relationships such as the loss of wildlife following the loss of habitat from a wildland fire. However, a wildland fire does not have a predetermined origin or path, that is, fires often occur as random acts of nature. In fact, the level of impact may differ depending on the intensity of the wildland fires and the level of emergency response. Therefore, this document relies on the evaluation of relative impacts more than on absolute impacts. Finally, DOE may take emergency actions to the extent necessary to contain, control, and extinguish wildland fires. ${ }^{1}$

At semiarid sites, such as the INEEL, wind and water erosion can contribute to surface water and groundwater pollution. Wind and water erodes soil and transports the sediment and ash to where it may be washed by subsequent rains into groundwater via deep injection wells or into surface water. Naturally occurring and manmade pollutants, such as trace metals, nutrients, pesticides, and radionuclides, may be associated with this soil potentially altering water quality. If water quality is sufficiently affected, the INEEL could exceed the standards for discharges to deep injection wells and surface water. Water quality has not been studied to document the effects of fire and fire-related activities at the INEEL. However, fire directly increases erosion by reducing vegetative cover and several fire-related activities directly increase erosion by disturbing soil. An altered fire frequency and recovery cycle increases the rate of erosion and decreases watershed stability.

Table 4-1 (see page 39) describes the potential environmental consequences of the alternative approaches to wildland fire management discussed in Section 2 on the air, water, wildlife/habitat, and cultural resources of the INEEL. The following sections compare the impact of each alternative approach on the management objectives and goals (see Section 1.4 and Appendix B) for each discipline, including whether it meets the management objectives of the INEEL Infrastructure Organization. Table 4-2 (page 46) summarizes the effect of each alternative on the management objectives of each discipline.

\subsection{Alternative 1 - Maximum Fire Protection Approach}

\subsubsection{Air Resources}

Alternative 1 would mostly meet the air resource management goals, since fire suppression and post-fire activities would meet most air quality objectives (Table 4-2 and Appendix B). However, pre-fire activities may not meet air quality objectives. Fugitive dust from these activities would likely be high relative to other alternatives because of the greater amount of activity, such as blading non-paved roads. Planning and direction from the wildland fire management committee would help mitigate some of this increased impact. Fugitive dust from fire suppression activities would likely be greater than for Alternatives 2 and 3, because of the aggressive fire suppression tactics used. However, smoke emissions from fires and subsequent dust emissions from burned areas would be smaller than for Alternatives 3 and

\footnotetext{
110 CFR 1021 states: "DOE shall consult with CEQ as soon as possible regarding alternative arrangements for emergency actions having significant environmental impacts. DOE-ID uses an environmental checklist process to determine if an activity (planned or emergency) constitutes a significant environmental impact. If there is a potential for significant impact, DOE-ID would prepare an Environmental Assessment.
} 
4, because fires would likely be smaller. Protecting SCAs would reduce or eliminate potential for spread of radiological contamination. However, contamination levels would be unlikely to cause human health or ecological concerns (see Table 3-1). Site restoration would continue to reduce long-term fugitive dust generation from burned areas.

\subsubsection{Water Resources}

Alternative 1 would likely meet water resource management objectives by using aggressive fire fuel management and fire suppression, dust suppression, and site restoration with implementation of recommendations from the Wildland Fire Management Committee (Table 4-2 and Appendix B). However, Alternative 1 would likely has-create the largest acreage of bare soil and would that be detrimental to water resources due to increased erosion from frequent soil disturbance and from invasive annual plant species that provide inferior soil stabilization when compared to native perennial vegetation. In addition, 32-ft wide unimproved roads would become increasingly deep and function as channels altering flow paths, increasing erosion, and flooding. Alternative 1 would-could result in few unwanted fires due to aggressive fuel management.

\subsubsection{Wildlife/Habitat Resources}

Alternative 1 would not meet all natural resource management objectives because of pre-fire, fire suppression, and post-fire and their associated activities (Table 4-2 and Appendix B). Although wildland fire management under this alternative may protect ecological resources from wildland fire, it will not protect the unique large, ecologically continuous sagebrush ecosystem from destruction because of the direct loss of habitat and fragmentation of habitat by pre-fire activities.

Fuel Management Zones - Although it causes a direct loss of some sagebrush habitat, creating fuel management zones along improved roads and gun ranges will limit the loss of sagebrush habitat to fire. Proper fuel management in these areas can reduce the risk of a large fire by limiting access to coarse woody fuels (shrubs). The method selected to reduce fuel loads will be important to defining the extent of the direct impacts. Methods that remove all of the native perennial vegetation (blading or soil sterilization) will increase the likelihood of weed invasion. Preventing weed invasions on these fuel management zones will require expensive maintenance on an annual basis. The maintenance activities required to support these fuel management zones will also likely result in additional risks to the remaining habitat by increasing the likelihood of ignitions and also by potential for weed management to damage non-target plant species. These fuel management zones will also be at risk to soil erosion. These effects will be minimized if mowing is used to remove only the coarse woody fuels leaving the remaining native perennial plants intact.

Creating fuel management zones by blading unimproved roads to a width of 32 feet will have significant impacts to ecological resources. This activity will result in substantial habitat fragmentation in addition to the direct loss of sagebrush habitat (see Appendix C). This activity will also likely result in widespread invasion of weeds into areas where this is currently not a major concern. Preventing weed invasions on these fuel management zones will require expensive maintenance on an annual basis. The maintenance activities required to support these fuel management zones will also likely result in additional risks to the remaining habitat by increasing the likelihood of ignitions and also by potential for weed management to damage non-target plant species. These fuel management zones will also be at risk to soil erosion.

Upgrading Unimproved Roads - Upgrading unimproved roads will have both direct and indirect effects on ecological resources. Many of the listed roads are presently two-track roads. Grading them will result in direct loss of sagebrush habitat. It will also lead to habitat fragmentation (see Appendix C). Improving roads will also likely lead to increased access and use for reasons other than fire suppression. Heavier human uses of these areas will likely lead to a reduction in habitat quality and increased fragmentation effects. Improving roads will likely increase soil erosion and weed invasion. 
Defensible Space - Creating defensible space around facilities will result in direct loss of habitat. These areas will also be prone to weed invasion and soil erosion as described above (see Appendix A). Mowing rather than blading firebreaks will have has fewer effects on ecological resources. This would be the preferred approach to providing protection near facilities and the primary paved roads.

Prescribed burning, if conducted properly, can have little impact to ecological resources. However, prescribed burning can put large areas of sagebrush steppe habitat at risk. This risk should be assessed separately for each prescribed fire.

Fire Suppression Activities - Fire suppression activities can also have direct and indirect impacts to ecological resources. The primary direct effects are caused by construction of containment lines. These effects are by direct loss of the vegetation on those sites and the increased likelihood of invasion by weeds (see Appendix A). Prominent among the weeds likely to invade is cheatgrass. Cheatgrass invasion increases the probability of fire ignition, because of the increase in fine fuels, and also increases the rate of fire spread. Containment lines can also result in habitat fragmentation (see Appendix C). However, it must be noted that construction of containment lines and firebreaks are important tools for controlling fire. The alternative to using these tools is an increased risk of larger fires that remove more sagebrush habitat.

Using backfires and burning large pockets of unburned vegetation will result in substantial loss of additional habitat.

Use of foam from the wildland heavy units and aerial fire retardant drops likely have little negative impact on ecological resources. Larson et al (1999) concluded that neither Phos-Check nor Silv-Ex had any disruptive effect on Great Basin shrub steppe vegetation communities. They cautioned, however, that their results did not address potential long-term impacts not seen in their one-year long study.

The use of water cannons to protect facilities will likely have little direct effect on ecological resources. However, care should be taken to minimize the potential for erosion. Use of the water cannons should be discontinued immediately after the fire danger has ended. Extended use can result in increased soil erosion and/or weed invasion. Application of soil tackifiers for post-fire dust control will likely have lesser ecological impacts than continued irrigation.

Fire suppression and pre-fire activities can have long-term impacts on ecological resources. Fuel management zones and containment lines create corridors that would have direct and indirect impacts to the ecosystem by changing the habitat characteristics from a continuous shrubland to a shrublands interspersed by grasslands. Construction of these corridors could also lead to soil degradation, edge effects, erosion, and invasion of undesirable species including non-native or exotic animals and plants (see Appendix C).

Direct and Indirect Impacts - Habitat fragmentation leads to increasing edge effects, loss of species diversity, alterations in natural disturbance regimes, and alterations in ecosystem functioning (Caling and Adams 1999). Increased edges can result in microclimatic changes in light, temperature, wind, humidity, and incidence of fire. Each of these effects can have a significant impact upon the number and kind of species associated with the edge.

Habitat fragments differ from original habitat in two important ways: 1) fragments have a greater amount of edge for the area of habitat, and 2) the center of each fragment is closer to the edge (Primack 1998). These changes are not beneficial to sagebrush obligates. 
Changes in the microenvironment at the fragment edge can result from habitat fragmentation. Some of the more important edge effects include microclimate changes in light, temperature, wind, humidity, decreased soil moisture, and incidence of fire (Shelhas and Greenberg 1996; Laurance and Bierregaard 1997; Reed et al. 1996). Each of these edge effects can have a significant impact upon the vitality and composition of species in the fragment and increased wind, lower humidity, and higher temperatures make fires more likely (Primack 1998). Edges produced by roads and fire lines can also increase nest parasitism by brown-headed cowbirds. Brown-headed cowbirds, the only obligate brood parasite in North America, feed primarily in open areas, but use perches to watch for nest building activities. Edge habitats are perfect for their needs (Brittingham and Temple 1983) and brood parasitism increases on edges and in fragmented habitats (Belthoff and Rideout 2000).

In shrub-steppe ecosystems, invading weeds, which were usually non-mycorrhizal, disrupted succession of native species, $99 \%$ of which were mycorrhizal -dependent. Also, fires have become more common and extensive in sagebrush ecosystems invaded by cheatgrass (Natural Resources Defense Council 2001). Presence of cheatgrass along edges (fire lines and roads) may allow it to invade burned patches, increasing the likelihood of fire spread into adjacent sagebrush patches, further fragmenting the ecosystem (Knick and Rotenberry 1997).

Disturbances such as fire and roads can increase the distance between remaining shrub patches that provide seed sources (Knick and Rotenberry 1997). The dominant shrub on the INEEL, big sagebrush, does not resprout from crown or roots following fire (Young and Evans 1978). Thus, natural regeneration of these shrublands could be severely limited by availability and dispersion of seed sources. Dispersal of sagebrush is primarily wind driven and occurs largely within 30-m of the seed source (Young and Evans 1989).

The direct impacts to wildlife and habitat resources that would result from the implementation of this alternative include habitat loss and habitat fragmentation. Direct impacts would include the immediate death of individual plants and animals that reside in the areas where fuel management zones and containment lines would be placed. Disturbance of soil will also increase erosion and invasion by nonnative vegetation. Additional edges resulting from present fire suppression activities could increase nest parasitism from brown-headed cowbirds and increase nest predation from predators that commonly use corridors, such as coyotes.

Indirect impacts would be those that reduce a population over time due to the change in ecological resources. The loss of resources impacts populations by increasing competition for resources and predation or parasitism. Creating corridors impacts the area by reducing the resource that provides nesting, foraging, and protection cover as well as potentially enhance the habitat for undesired species. Corridors also could result in the separation of populations by creating corridors with pre-fire and fire suppression activities, resulting in potential isolation and weakening of the gene pool.

This alternative may also cause the reduction or elimination of some species. Pre-fire and fire suppression activities would result in increased habitat and resource reduction over time due to the relatively slow recovery time of the sagebrush steppe ecosystem from disturbance. This will result in increased fragmentation impacts such as reduction in habitat, edge effects, fire suppression of plant and animal dispersal, increased erosion, increased invasion by non-native or more competitive species (resulting in the elimination or reduction of native but less competitive species), and potential reduction in genetic diversity.

Threatened and Endangered Species - Several species listed as species of concern by the FWS could be impacted severely or eliminated if long-term destruction of habitat results from pre-fire and fire suppression activities. These species include the sage grouse, pygmy rabbit, Merriam's shrew, long- 
billed curlew, northern sagebrush lizard, ferruginous hawk, loggerhead shrike, and painted milkvetch. There is potential that any of these species could be listed by the FWS as Threatened or Endangered on under the ESA, which would require habitat recovery. As pre-fire and fire suppression fragmentation and habitat destruction increases over time, it will be much more difficult and costly to restore viable habitat.

The FWS has indicated ${ }^{1}$ concerns about several plants and animals that may occur on the INEEL (see Table 3-2). Although these species have no status under the ESA, FWS is concerned about their population status and threats to their long-term viability. In context with ecosystem-level management, the FWS suggests that these species and their habitats be considered in project planning and review.

Due to the large number of "species of concern" on the INEEL (see Table 3-2) and the FWS suggestion that these species and their habitats be considered in project planning and review (see Section 3.4), it is recommended that the U.S. FWS be asked for consultation regarding the management of these species and their habitat on the INEEL if Alternative 1 is selected. Such a consultation will provide insight on species and habitat management, which will be critical if any of these species become listed under the ESA. This consultation will also minimize impacts to these species and their habitats during wildfire prefire, fire suppression, post fire and rehabilitation.

Wildland Fire Management Committee - The impact of many of the effects described above could be reduced through appropriate planning by the Wildland Fire Management Committee. This would include consideration of these impacts when designing the pre-fire activities and proper rehabilitation of areas impacted by fire suppression activities (post-fire).

\subsubsection{Cultural/Historical Resources}

Alternative 1 would not meet all cultural resource objectives (Table 4-2 and Appendix B). Activities described in Section 2.1 (see Table 2-1), such as blading, sterilizing, mowing and prescribed burning are more extensive under this alternative than Alternatives 2, 3, or 4, and would thus disturb more surface area. Unimproved road mileage identified for vegetation removal ( $16 \mathrm{ft}$ from the middle of the road to each side) totals 126 miles under Alternative 1, while Alternatives 2, 3 and 4 have no vegetation removal planned along any non-paved roads. In addition, firebreak construction as described under Alternatives 1 and 4 (Table 2-1, "Indirect Tactic") have the potential to adversely affect the contextual information of cultural resources by bisecting sites, churning under or damaging cultural resources. Application of MISTs under Alternative 2 would reduce the potential of adverse affects to cultural resources by limiting soil disturbance, with Alternative 3 identified as the most benign alternative with no firebreaks proposed.

However, under Alternative 1 advanced planning and coordination by a Wildland Fire Management Committee would allow for the development of mitigation and management plans that would contribute to the identification, evaluation and protection of cultural resources as required by federal law.

Conducting cultural resource surveys before creating firebreaks and mowing, minimizing disturbance of soil from heavy equipment operation and vehicular travel in general, and cultural resource site avoidance as a form of preferred mitigation could be practiced under this alternative. A Wildland Fire Management Committee is not proposed for either Alternative 3 or 4 , but is included under Alternative 2.

\subsection{Alternative 2 - Balanced Fire Protection Approach}

\subsubsection{Air Resources}

\footnotetext{
${ }^{1}$ Letter from Snake River Basin Office, USFWS to Roger Blew, September 1, 2001; Department of Energy, Idaho National Engineering and Environmental Laboratory Species List Update; 1-4-01-SP-1118/Updates \#1-4-01-SP$826 / 506.0000$
} 
Alternative 2 would mostly meet the air resource management goals since pre-fire and post-fire activities would meet all air quality objectives, and fire suppression activities would meet most air quality objectives (Table 4-2 and Appendix B). Planning and direction from the wildland fire management committee would help minimize impact from pre-fire actions. Smoke and post-fire dust emissions could exceed those of Alternative 1, since fires would be fought with less aggressive tactics, such as using MIST. Site restoration would reduce long-term fugitive dust, including post-fire radiologically contaminated dust, should the SCA burn. Even if that occurs, downwind spread of the very low-level radiological contamination is unlikely to cause human health or ecological concerns (see Table 3-1).

\subsubsection{Water Resources}

Alternative 2 would most effectively meet water resource management objectives by using aggressive fuel management, soil stabilization, MIST, dust suppression, and site restoration (Table 4-2 and Appendix B). Alternative 2 likely has the least pollutant exposure from soil sterilants, herbicides, and fire-inhibiting chemicals. Alternative 2 would result in few unwanted fires due to aggressive fuel management. In addition, Alternative 2 would protect water quality because of stable soil condition.

\subsubsection{Wildlife/Habitat Resources}

Alternative 2 would meet most natural resource management objectives (Table 4-2 and Appendix B). Wildland fire management under this alternative should protect ecological resources from pre-fire, fire suppression, and post-fire activities through mitigation strategies and MIST.

Fuel Management Zones - The impacts from creating fuel management zones is the same as Alternative 1 , except there would be no impacts along unimproved roads since Alternative 2 would not create fuel management zones along unimproved roads (see Section 4.13). This difference means that there would be fewer acres of direct habitat loss and less habitat fragmentation.

Upgrading Unimproved Roads - Upgrading unimproved roads so that they are passable, at a minimum, by $4 \mathrm{X} 4$ vehicles will have lesser impacts than those described for Alternative 1. Many of the listed roads are presently two-track roads and for the most part are passable by $4 \mathrm{X} 4$ vehicles. Further improvement of these roads will also likely lead to increased access and use for reasons other than fire suppression. Heavier human uses of these areas will likely lead to a reduction in habitat quality and increased fragmentation effects.

Defensible Space - The impacts from creating defensible space is the same as Alternative 1, except there would be no impacts from prescribed burning since Alternative 2 would not use prescribed burning as a method to create defensible space. In addition, there would be little impact associated with creating defensible space around SCAs, since this alternative would protect only two SCAs (see Section 4.1.3).

Fire Suppression Activities - The impacts associated with fire suppression activities are the same as Alternative 1 (see Section 4.1.3) with the exception of the addition of MIST.

Direct and Indirect Impacts - The direct and indirect impacts are the same as Alternative 1, except Alternative 2 includes the use of MISTs (see Section 4.1.3). The incorporation of MIST into the fire suppression activities would lessen the impacts of the emergency response to some fires. For example, the use of cold trailing rather than blading containment lines results in less soil disturbance, decreased likelihood of weed invasion, reduced habitat fragmentation and edge effects. It also greatly decreases the need for site restoration.

Threatened and Endangered Species - The impacts to T\&E species is the same as Alternative 1 (see Section 4.1.3) except for the use of MIST and the impacts related to the pre-suppression construction of 
the firebreaks. Construction of the firebreaks willwould result in a direct loss and fragmentation of sagebrush steppe habitat.

Wildland Fire Management Committee - The benefits of putting togetherestablishing a Wildland Fire Management Committee are the same as Alternative 1 (see Section 4.1.3).

\subsubsection{Cultural/Historical Resources}

Alternative 2 would not meet all of the cultural resource objectives (Table 4-2 and Appendix B). However, following MIST would reduce damage to cultural resources and minimize contextual loss by limiting the amount of soil to be disturbed. No vegetation removal along unimproved roads is proposed under Alternative 2, 3 or 4, but is extensive under Alternative 1 (126 miles). In addition, Alternative 1 proposes conducting prescribed burns to eliminate excessive fuel loads, an activity that may adversely affect cultural resources if off-road vehicular travel occurs, while Alternatives 2, 3 and 4 do not propose prescribed burning. During fire suppression activities under Alternative 2, tactics such as minimization of width and depth of containment lines, cold-trail tactics, and most importantly, the use of existing roads as containment lines, greatly reduces the potential to damage cultural resources (MIST).

Alternative 2, as in Alternative 1, allows for advanced planning and coordination by a Wildland Fire Management Committee for the development of mitigation and management plans that would contribute to the identification, evaluation and protection of cultural resources as required by federal law. As in Alternative 1, conducting cultural resource surveys before creating firebreaks and mowing, minimizing disturbance of soil from heavy equipment operation and vehicular traffic in general, limiting the width and depth of containment lines, integrating containment lines into existing natural breaks (such as lava outcrops, ridges) and cultural resources site avoidance as a preferred form of mitigation could be practiced under this alternative.

\subsection{Alternative 3 - Protect Infrastructure and Personnel Safety Approach}

\subsubsection{Air Resources}

Alternative 3 would not meet most air resource management goals, since fire suppression and post-fire activities would not meet air quality objectives (Table 4-2 and Appendix B). Only pre-fire activities would meet air quality objectives because they can be planned and carried out under controlled conditions to minimize impacts to air quality.

Emissions from fires and subsequent dust emissions from burned areas would likely be larger and longer in duration than for the other alternatives. Fugitive dust from equipment operations during fire suppression activities would likely be the lowest relative to the other alternatives, since ground disturbance occurs only at threatened facilities. Under Alternative 3, SCAs would not be protected. Therefore, the potential for downwind spread of radiological contamination during and after a fire through an SCA would be larger than for Alternatives 1 and 2. However, contamination levels would be unlikely to cause human health or ecological concerns (see Table 3-1).

\subsubsection{Water Resources}

Alternative 3 would not meet water resource management objectives because fire suppression activities would allow for frequent, and large wildland fires leading to increased soil erosion, weed infestation, and loss of watershed stability (Table 4-2 and Appendix B). Therefore, Alternative 3 would have the greatest impact to water resources of all the alternatives.

\subsubsection{Wildlife/Habitat Resources}


Alternative 3 would not meet all natural resource management objectives because of fire suppression activities. Wildland fire management under this alternative will would not protect ecological resources from unwanted fire and could result in large areas of sagebrush habitat burned. In addition, pre-fire activities are limited to areas immediately surrounding threatened facilities; therefore, short-term impacts would be less. However, long-term impacts from the loss of habitat site-wide could result in long-term impacts to the vegetation and wildlife.

Fuel Management Zones - Creating fuel management zones around facilities will result in direct loss of habitat. These areas will would also be prone to weed invasion and soil erosion as described above (see Appendix A). Mowing rather than blading firebreaks will havehas fewer effects on ecological resources. This would be the preferred approach to providing protection near facilities and the primary paved roads.

Upgrading Unimproved Roads - Upgrading unimproved roads is not part of this alternative.

Defensible Space - The impacts associated with creating defensible space are the same as Alternative 1, except, there would be not impacts from protecting SCAs.

Fire Suppression Activities/Direct and Indirect Impacts - The greatest difference between this alternative and the others is that there is no goal of containing the fire. As such, creating containment lines is not part of this alternative. Because no containment lines are created, many of the concerns over habitat fragmentation, creation of new corridors, and edge effects are not important considerations in this alternative. Not creating containment lines also means that the potential for invasion by non-native plants is greatly reduced, as is the need for restoration. However, the direct loss of sagebrush habitat due to uncontained wildland fire could be a significant impact of this alternative.

Threatened and Endangered Species - The impacts to T\&E species is the same as Alternative 1 (see Section 4.1.3).

Wildland Fire Management Committee - This alternative does not consider using a Wildland Fire Management Committee, thus there would be no benefits as described in previous alternatives.

\subsubsection{Cultural/Historical Resources}

Alternative 3 in many ways meets all of the cultural resources objectives (Table 4-2 and Appendix B). Damage caused by pre-fire management and fire suppression activities, such as containment line and firebreaks, grading, blading, mowing, grubbing, and re-seeding or off-road travel is greatly reduced or eliminated; thus Alternative 3 would result in the least disturbance to soil and cultural resources. While this alternative does not utilize MIST in conjunction with fire suppression activities, these suppression activities would be restricted to gun range and facility perimeters only, as opposed to the 890 square miles of INEEL acreage that could be affected by activities proposed under Alternatives 1, 2 and 4.

\subsection{Alternative 4 - No Action or Traditional Fire Protection Approach}

\subsubsection{Air Resources}

Alternative 4 would not meet most air resource management goals (Table 4-2 and Appendix B). Fire suppression and post-fire activities would not meet air quality objectives, because MIST would not be used for suppression, and no restoration of burned sites would be conducted. Only pre-fire activities would meet most air quality objectives. Fugitive dust from pre-fire activities would likely be less than for Alternative 1, but some practices, such as improving unimproved roads, would result in increased dust emissions over Alternatives 2 and 3. Fugitive dust would likely be greatest for this alternative. Additionally, SCAs would not be protected under Alternative 4. Therefore, the potential for downwind 
spread of radiological contamination during a fire would be greater than that for Alternatives 1 and 2; and similar to Alternative 3. H however, contamination levels would be unlikely to cause human health or ecological concerns (see Table 3-1).

\subsubsection{Water Resources}

Alternative 4 would not meet water resource management objectives due to poor fuel management and lack of site restoration (Table 4-2 and Appendix B). The following impacts would contribute to the overall impact to water resources: (1) loss of watershed stability due to soil erosion and invasive plants; (2) increasing difficulty achieving soil stabilization with vegetation; (3) degradation of water quality due to soil sedimentation; (4) reduced capacity of wastewater facilities due to soil sedimentation; (5) degradation of groundwater due to increased sediment and ash concentrations in storm water discharges to deep injection wells; and (6) clogged ditches, culverts, and channels due to soil sedimentation increasing the potential for ice dam formation, causing flooding and contact between water and sources of pollution such as outdoor material and equipment storage areas.

\subsubsection{Wildlife/Habitat Resources}

Alternative 4 would not meet all natural resource management objectives because of fire suppression and its associated activities (Table 4-2 and Appendix B). Wildland fire management under this alternative may protect ecological resources from wildland fire, but will not protect resources from pre-fire and fire suppression activities.

Fuel Management Zones - The impacts from creating fuel management zones is the same as Alternative 1 , except it should be noted that compared to Alternatives 1 and 2, the fuel management zones along the paved roads would only extend to $10 \mathrm{ft}$. rather than up to $300 \mathrm{ft}$. and are, therefore less likely to be as effective at confining a fire to the area adjacent to the road.

Upgrading Unimproved Roads - Upgrading unimproved roads is not part of this alternative.

Defensible Space - The impacts associated with creating defensible space are the same as Alternative 1, except, there would be not impacts from protecting SCAs and there would be no impacts from prescribed burning would-since this alternative would not use prescribed burning as a method to create defensible space.

Fire suppression Activities - The impacts associated with fire suppression activities are the same as Alternative 1, except there would be no impacts from backfires since backfires would not be part of this alternative (see Section 4.1.3).

Direct and Indirect Impacts - The direct and indirect impacts are the same as Alternative 1 (see Section 4.1.3).

Threatened and Endangered Species - The impacts to T\&E species is the same as Alternative 1 (see Section 4.1.3).

Wildland Fire Management Committee - This alternative does not consider using a Wildland Fire Management Committee, thus there would be no benefits as described in previous a 1 lternatives 1 and 2 . 


\subsubsection{Cultural/Historical Resources}

Alternative 4 would most likely result in the most damage to cultural resources because of the lack of opportunity for planned mitigation before fire suppression activities (that is, no Wildland Fire Management Committee); thus, it does not meet cultural resource goals (Table 4-2 and Appendix B). Impacts from pre-fire, fire suppression, and post-fire activities, such as firebreak and containment lines and off-road travel, would be greater than for all other alternatives, and no damage assessments or site restoration activities are proposed under this alternative. 


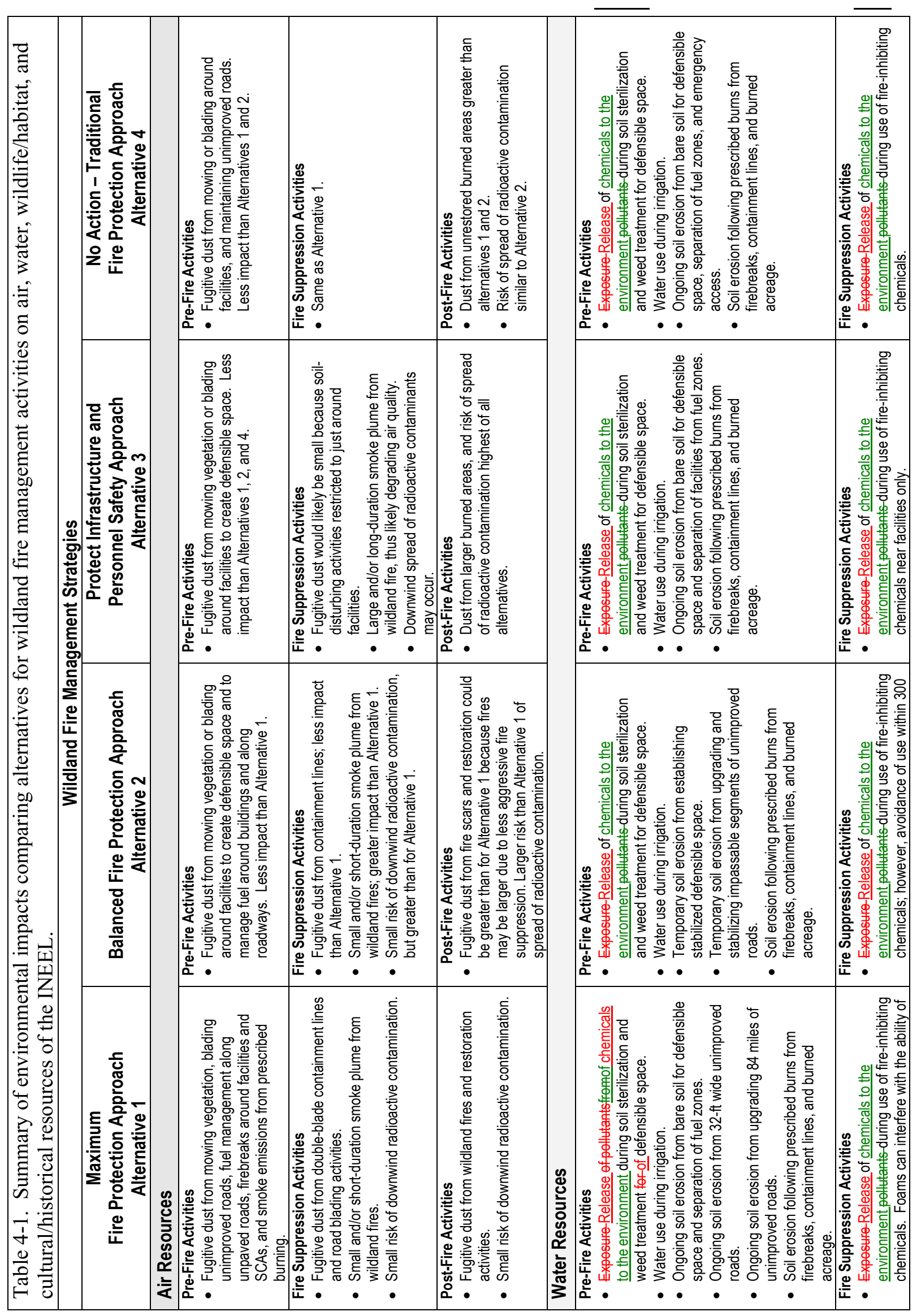




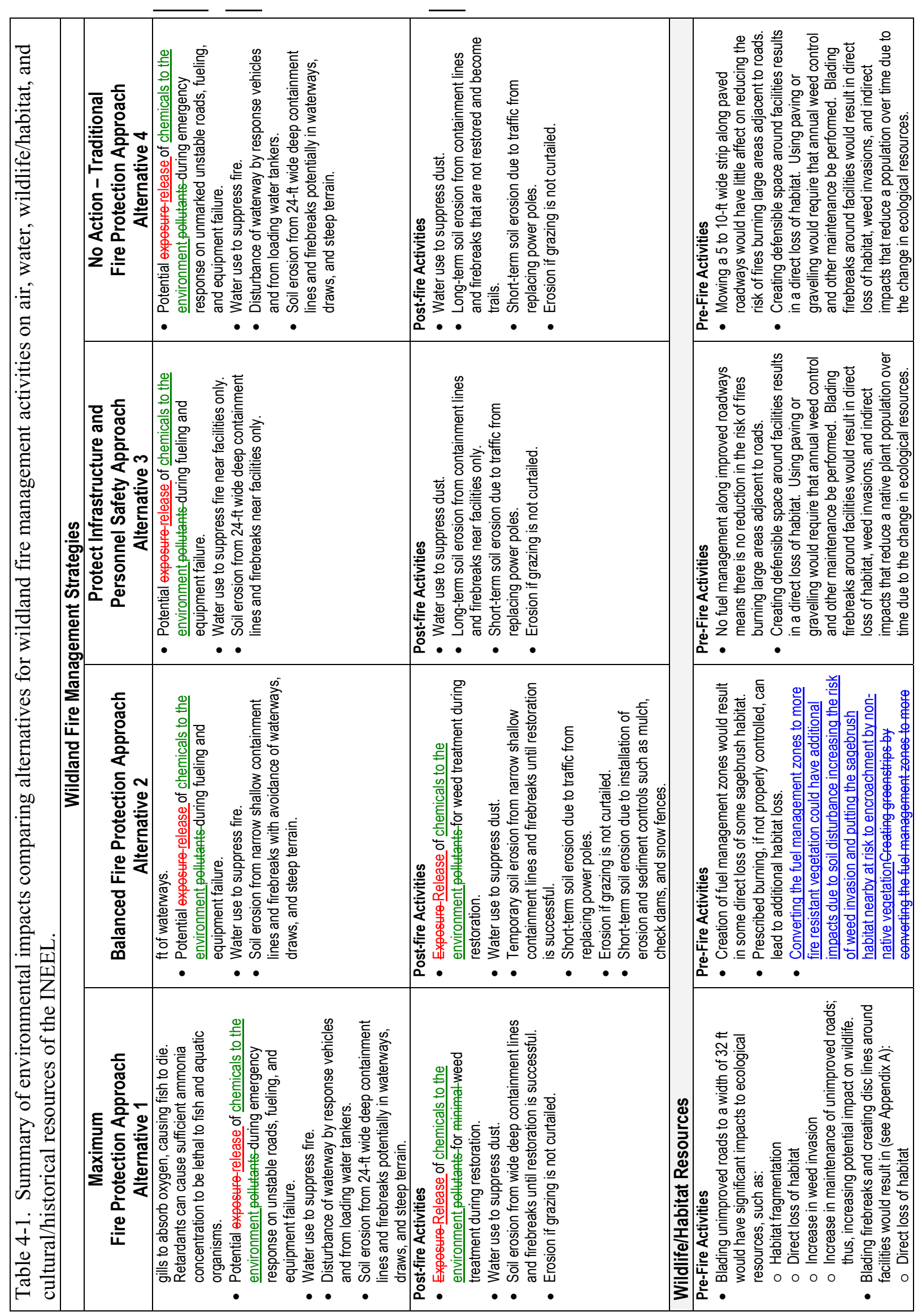




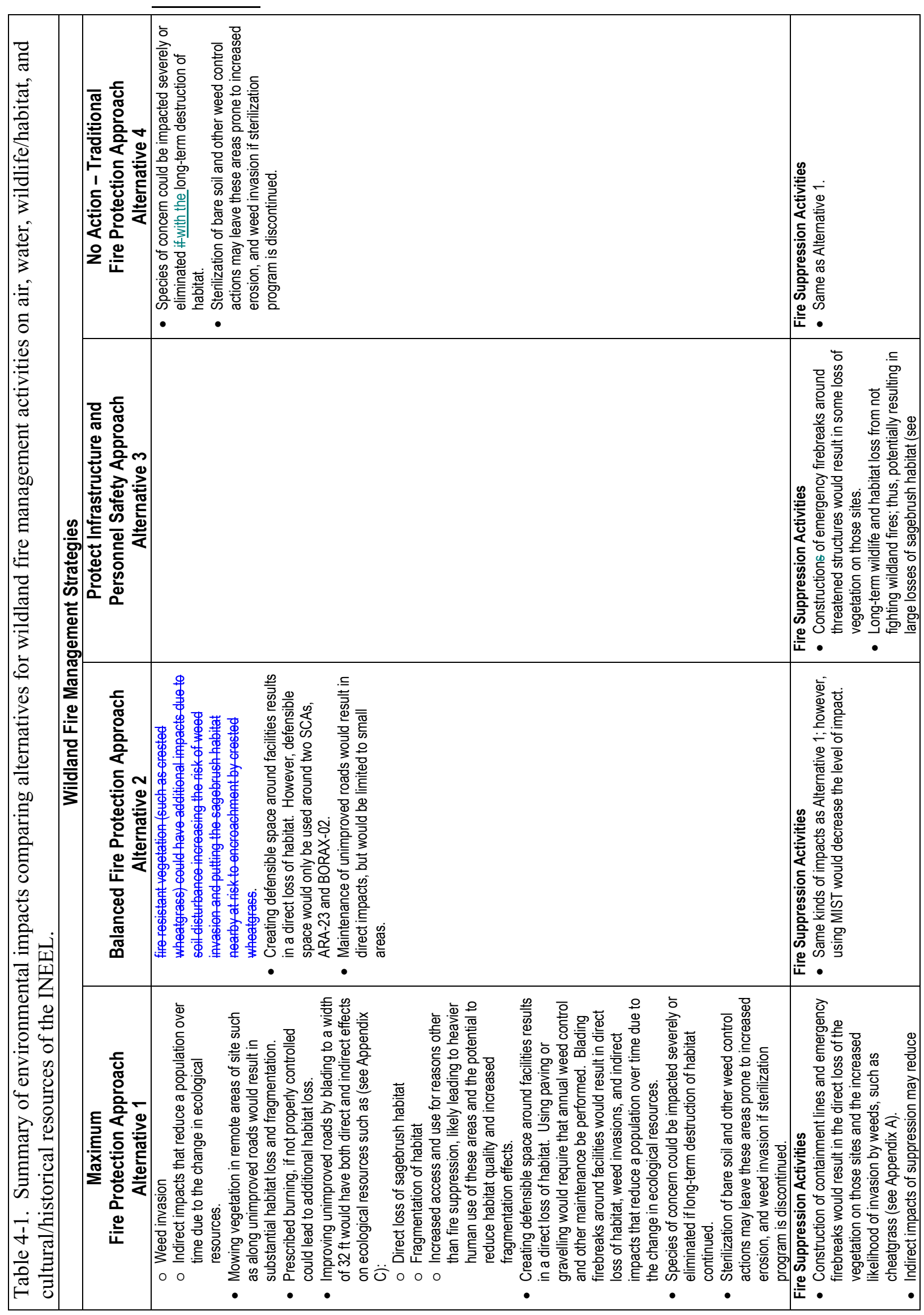




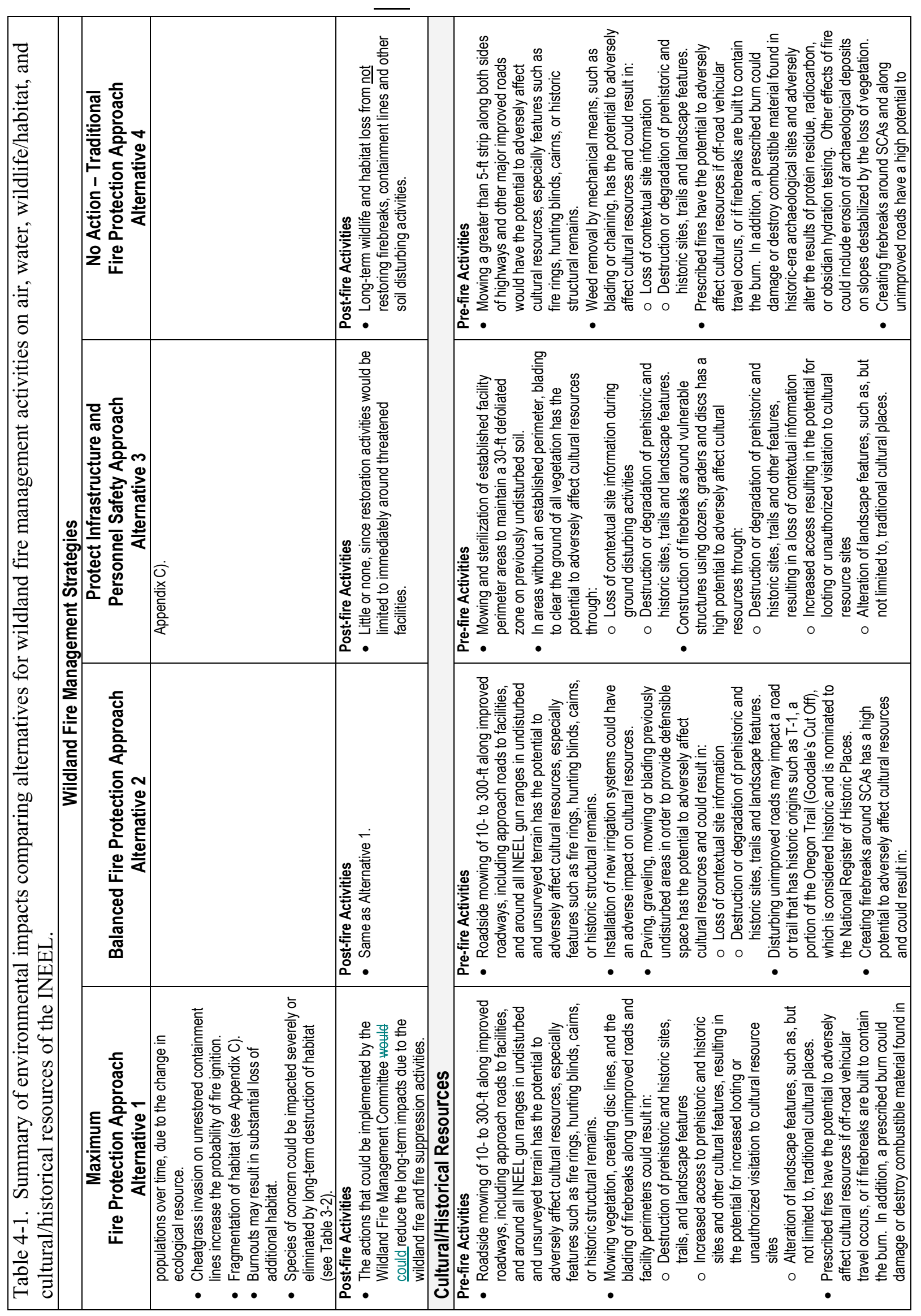




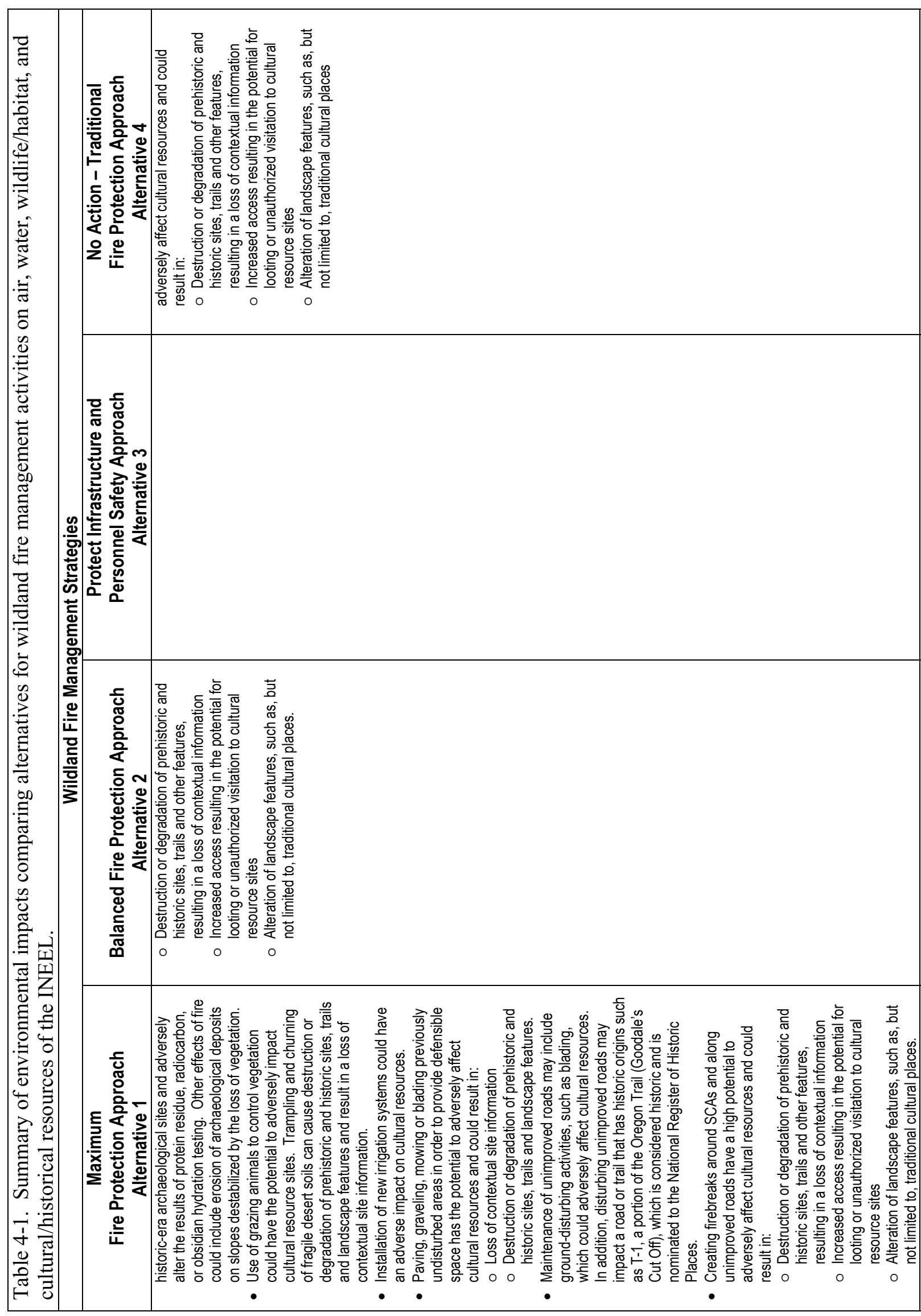




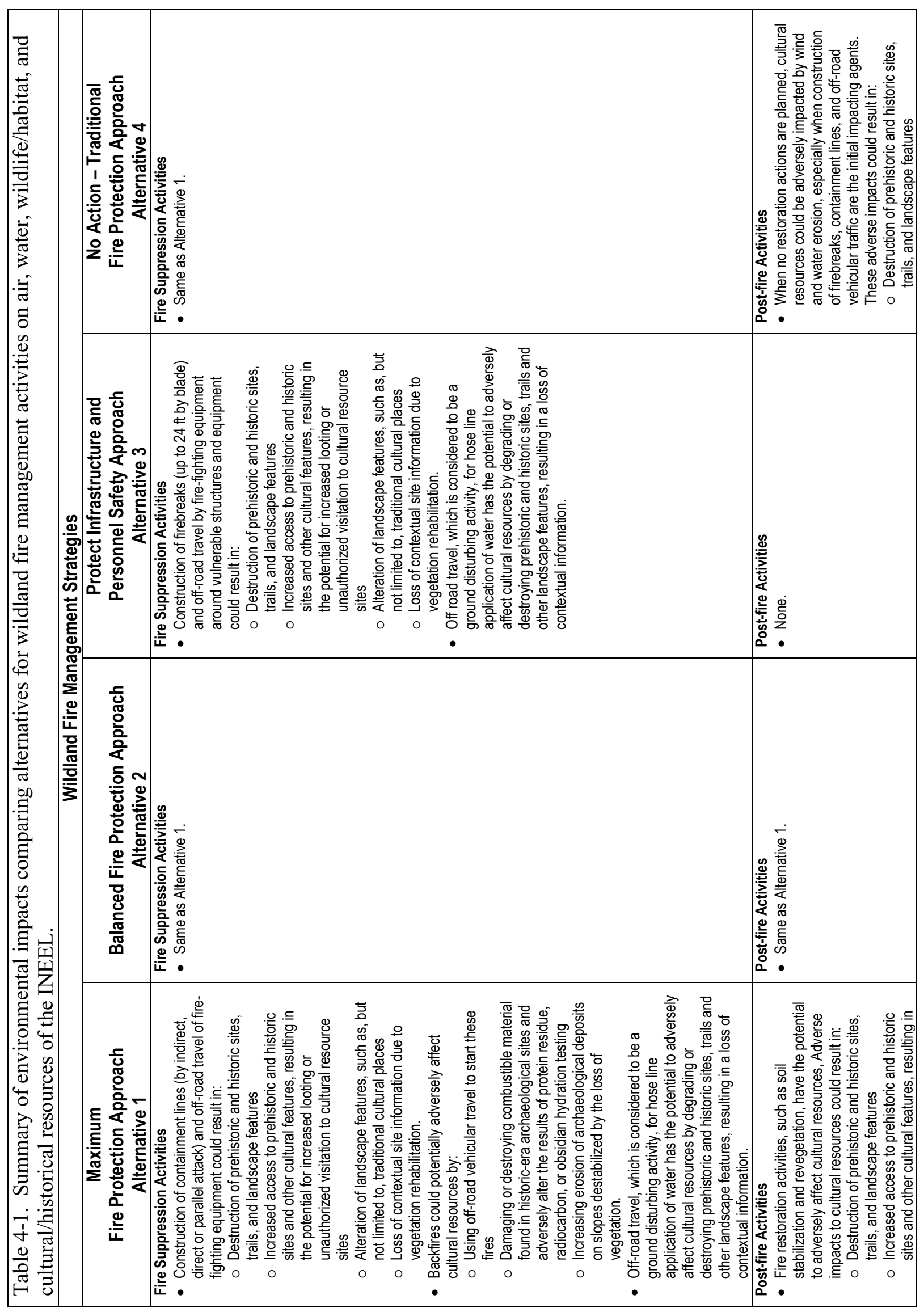




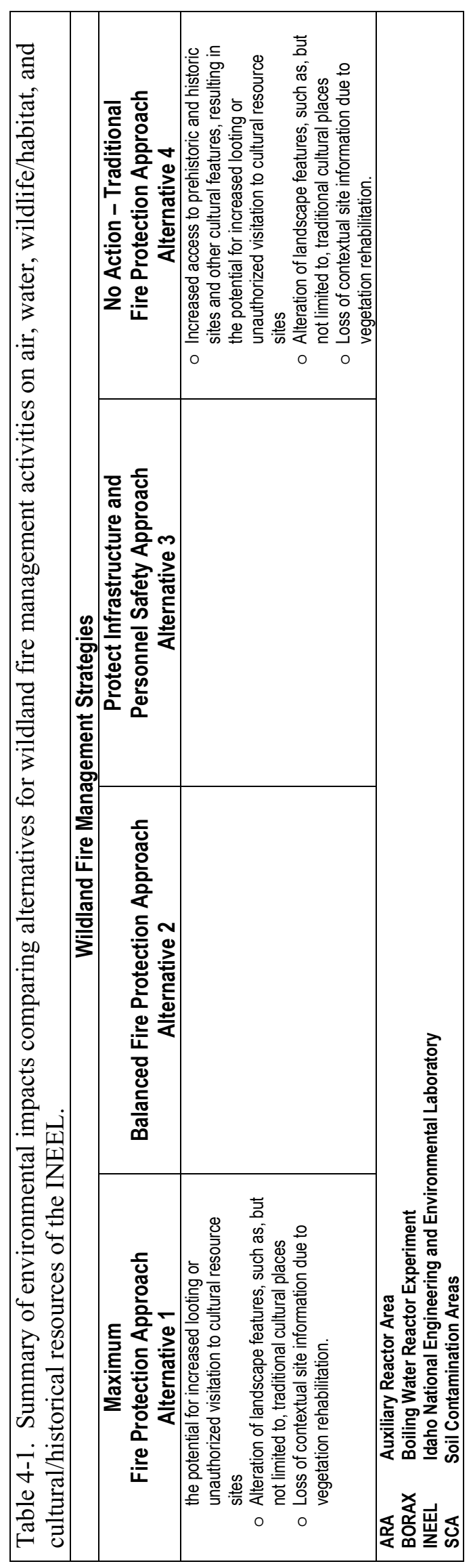




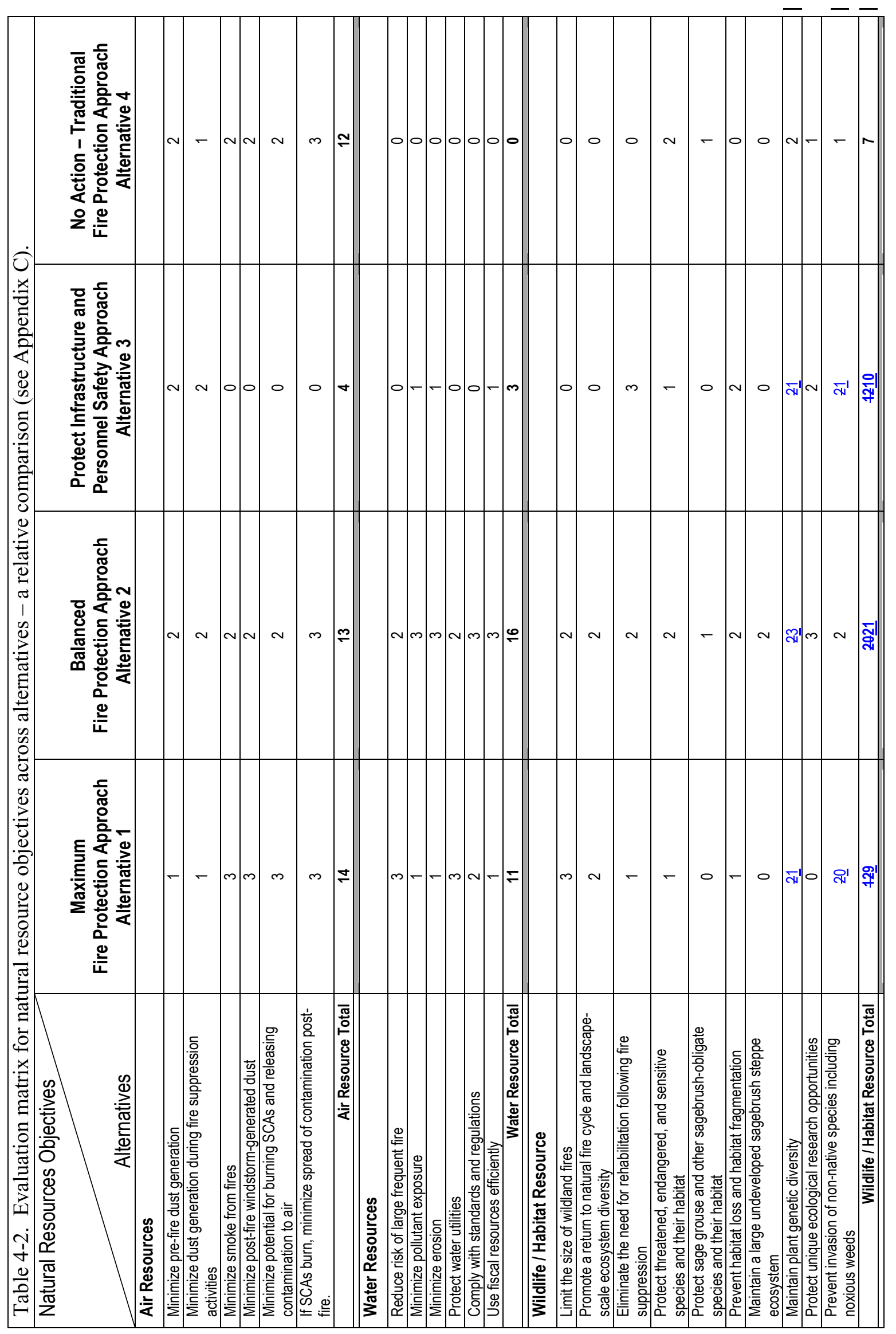




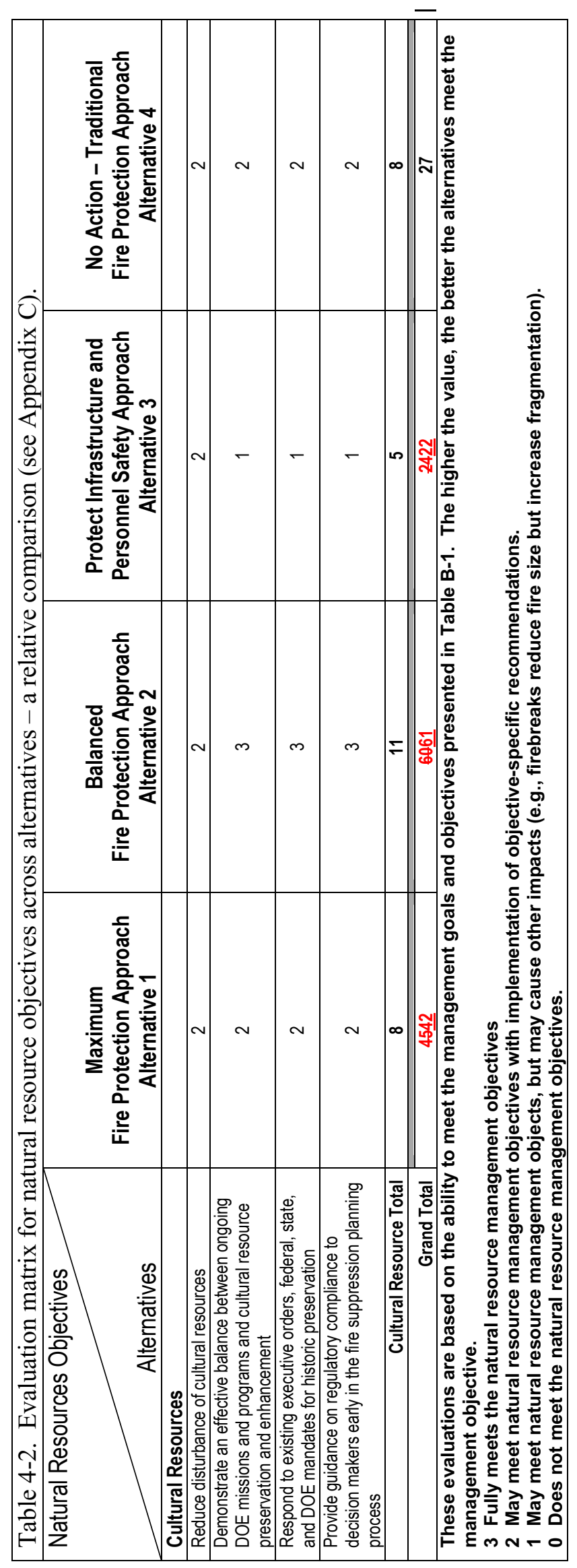




\section{COORDINATION AND CONSULTATION}

The following agencies and individuals were contacted for information regarding environmental resources on or near the INEEL.

- Joe Lowe and Russ MacFarling, BLM, Idaho Falls, ID concerning sage grouse habitat requirements. Meeting on February 13, 2001.

- Steve Schmidt, Idaho Department of Fish and Game, Idaho Falls, ID concerning sage grouse habitat. Meeting on February 13, 2001.

- Alison B. Haas, FWS, Boise, ID concerning threatened, endangered, candidate and other species of concern. Letter dated September 1, 2001. Subject: DOE, Idaho National Engineering and Environmental Laboratory Species List Update, 1-4-01-SP-1118/Updates\#1-4-01-SP$826 / 526.0000$.

- G. Stephens, Idaho Department of Fish and Game, Boise, ID concerning threatened, endangered, candidate and other species of concern. E-mail dated November 16, 2001, subject: INEEL sensitive species.

DOE received comments from the following groups on the initial annotated outline of the EA:

- The Shoshone-Bannock Tribes, letter from Diana Yupe, dated March 7, 2001

- The Idaho National Engineering and Environmental Laboratory Citizens Advisory Board, letter from Stan Hobson, dated March 23, 2001.

DOE provided the following groups an opportunity to comment on the draft EA. DOE received comments and incorporated suggestions from the BLM and Idaho Department of Fish and Game.

- Bureau of Land Management, Idaho Falls District Office, Idaho Falls, ID, Mr. Rick Belger, Fire Management Officer, July 3, 2002

- Bureau of Land Management, Pocatello, ID, Mr. Terry Smith, July 3, 2002

- Bureau of Land Management, Sagebrush Steppe Ecosystem Reserve, Project Manager, Idaho Falls District Office, Idaho Falls, ID, Mr. Ken Thacker, Project Manager, July 5, 2002

- Facilitation and Public Participation Service, Jason Associates Corporation, Idaho Falls, ID, Mr. David Kipping, July 3, 2002

- Idaho Department of Fish and Game, Idaho Falls, ID, Mr. Steve Schmidt, Regional Wildlife Habitat Manager, July 3, 2002

- Shoshone-Bannock Tribes, Fort Hall, ID, Ms. Diana Yupe, July 8, 2002

- State of Idaho Department of Transportation, Rigby, ID, Mr. Tom Cole, July 5, 2002

- U. S. Fish and Wildlife Service, Eastern Idaho Field Office, Chubbuck, ID, Ms. Debra Mignogno, July 3, 2002

- U. S. Forest Service, Idaho Falls District Office, Idaho Falls, ID, Mr. Keith Birch, July 5, 2002. 


\section{PERMITS AND REGULATORY REQUIREMENTS}

Air Resources:

CAA of 1970 (CAA - 42 U.S.C. 7401 et seq.). Section 118 of the CAA (42 U.S.C. 7418) requires that each federal agency with jurisdiction over any property or facility that might discharge air pollutants comply with "all Federal, state, interstate, and local requirements" with regard to the control and abatement of air pollution. Standards established by EPA under the CAA are implemented through state implementation plans developed by each state with EPA approval. The CAA requires sources to meet standards and obtain permits to satisfy these standards. Air emissions are regulated by the EPA under 40 Code of Federal Regulation (CFR) Parts 50 through 99. Radionuclide emissions are regulated under the National Emission Standards for Hazardous Air Pollutants Program under 40 CFR Part 61.

Fugitive dust emissions are subject to Idaho Administrative Procedure Act (IDAPA) 16.01.01.650, "Idaho Rules for Control of Fugitive Dust." In addition, controlled burns are subject to IDAPA 58.01.01.614, "Prescribed Burning."

\section{Water Resources:}

Activities in areas where storm water could discharge to water subject to the Clean Water Act and that could pollute storm water must be conducted according to the National Pollutant Discharge Elimination System (40 CFR 122). Fire-related activities could pollute storm water when soil is disturbed to maintain firebreaks and when pollutants are releasedchemicals are used to sterilize soil. Pollution prevention practices are outlined in permits for storm water discharges (EPA 1998 and EPA 2000): mulches to control erosion, check dams to control sediment, perennial vegetation to permanently stabilize soil, and spill prevention to minimize pollutant exposure.

The relationship between erosion and personnel activities related to fire also has the potential to influence compliance with the State of Idaho Injection Well Permits (IDAPA 37.03.03). Storm water discharges to deep injection wells are monitored and analytical data are submitted to the Idaho Department of Water Resources.

Due to sedimentation of waterways, actions may be necessary to maintain drainage and manage flood hazards after a fire to comply with the "Natural Phenomena Hazards Design and Evaluation Criteria for DOE Facilities," DOE-STD-1020. The document addresses earthquake, wind, and flood hazards; however, wildfire is not addressed. Flood design and evaluation criteria consider the design of safety structures, systems, and components for regional flood hazards and local precipitation that effect site drainage.

A Idaho Stream Channel Alteration Permit (IDAPA 37.03.07) or Army Corp of Engineers Nationwide Permit (33 CFR 330) would be required for road upgrades across waterways and removal of sediment from some waterways, for example to prevent ice jams and reduce flood hazards after a fire causes sedimentation of waterways.

Grazing may be restricted after a fire by the BLM to ensure compliance with the State water quality standards according to 43 CFR 4180.1, "Fundamentals of Rangeland Health." Water quality standards are established by the State of Idaho according to 40 CFR 131, "Water Quality Standards." (Except, the EPA established the water temperature criteria for bull trout in 40 CFR 131.33, "Subpart D - Federally Promulgated Water Quality Standards, Idaho," which affects the Little Lost River basin.) The Big Lost River, Birch Creek, and Little Lost River are protected from their sources to the playas. 
Water use for water cannons, tankers, and irrigation systems must be according to the "Water Rights Agreement between the State of Idaho and the United States, for the DOE," 1990, until the INEEL water rights are adjudicated.

A watershed management approach must be implemented when protecting and restoring watersheds according to the "Unified Federal Policy for a Watershed Approach to Federal Land and Resource Management" (65 FR 62565).

\section{Wildlife/Habitat Resources:}

Soil disturbing activities related to fire have the potential to increase noxious weeds and invasive plant species that must be managed according to the "Management of Undesirable Plants on Federal Lands" (7 USC 2814) and the Invasive Species Executive Order (EO 13112).

Under the ESA (16 U.S.C. 1531 et seq.), DOE is required to review as guidance the most current FWS list for T\&E plant and animal species. If after reviewing the list, DOE determines that the proposed action would not impact any T\&E species, DOE may determine or document that formal consultation with the FWS is not required for this action. A biological assessment may be recommended for the proposed or alternative actions.

Other Federal Regulations DOE may be required to consult before implementing the proposed action or any of the alternatives include the Fish and Wildlife Coordination Act (16 U.S.C. § 661 et seq.), Bald Eagle Protection Act (16 U.S.C. $\S \S 668$.), Clean Water Act (33 U.S.C. 1251 et seq.), Emergency Wetlands Resources Act (16 U.S.C. $\S \S 3901-3932$ ), Migratory Bird Conservation Act (16 U.S.C. $\S 715$ to 715s), and North American Wetlands Conservation Act (16 U.S.C. $§ 4401$ et seq.).

\section{Cultural/Historical Resources:}

In compliance with the NHPA and its implementing regulations (36 CFR 800), all cultural resource evaluations and recommendations are subject to review by the Idaho State Historic Preservation Office. DOE-ID's "Working Agreement" with the Shoshone-Bannock Tribes also mandates consultation on cultural resource issues.

Various federal and state laws, regulations and DOE directives protect cultural resources on federal lands such as the INEEL. One of the most far-reaching laws is the NHPA of 1966 (NHPA - PL 89 665; 16 USC 470). Specifically, protection of prehistoric and historic sites is facilitated through implementation of the NHPA Section 106 review (36 CFR 800), which is a five-step process designed to ensure that cultural resources are considered during planning stages and before any ground disturbing activities by Federal projects. In addition, all cultural resource evaluations and recommendations are subject to review by the Idaho State Historic Preservation Office. DOE-ID's “working Agreement" with the ShoshoneBannock Tribes also mandates consultation on cultural resource issues before any ground disturbing activities by Federal projects. Examples of ground disturbing activities that require action under these laws and agreements include, but are not limited to, road blading, trenching, mowing vegetation or sterilization of any INEEL property, and prescribed burns.

\section{Shoshone-Bannock Tribal Interest:}

DOE-ID recognizes the Shoshone-Bannock 1868 Fort Bridger Peace Treaty as a supreme law of the land that has not been abrogated by time. Additionally, DOE-ID recognizes the tenant responsibility and agrees to conduct all activities by providing opportunities for consultation and collaboration to the Shoshone-Bannock Tribes (Tribes) as required by, and pursuant to all applicable Public Laws, Executive 
and DOE Orders, Policies (such as DOE American Indian and Alaskan Native Tribal Government Policy) and the DOE-ID/Shoshone-Bannock Agreement in Principle. 


\section{REFERENCES}

Anderson, J. E., K. T. Ruppel, J. M. Glennon, K. E. Holte, and R. C. Rope, 1996, Plant communities, ethnoecology, and flora of the Idaho National Engineering Laboratory. Environmental Science and Research Foundation Report No. 005. Environmental Science and Research Foundation, Idaho Falls, ID. $111 \mathrm{pp}$. 23

Anderson, J.E. and R.S. Inouye, 2001, Landscape-scale changes in plant............................................ 23

Arrowrock Group, Inc., 1998, "The National Engineering and Environmental Laboratory, A Historical Context and Assessment, Narrative and Inventory," INEEL/EXT-97-01021 .................................... 25

Belthoff, J. R. and C. W. Rideout. 2000. Effects of Habitat Fragmentation on Shrub-steppe Birds in Southeastern Idaho. 2000 Interim Report, Boise State University, Boise, Idaho.......................... 31, 75

Brittingham, M. C. and S. A. Temple. 1983. Have cowbirds caused forest songbirds to decline? Bioscience 33: 31-35.

Caling, T. M. and R. Adams. 1999. Ecological Impacts of Fire Suppression Operations in a Small Vegetation Remnant. Proceedings of the Australia Bushfire Conference, Albury Australia, July 1999.

Clawson et al., 1989, Clawson, K. L., G. E. Start, and N. R. Ricks, 1989, Climatography of the Idaho National Engineering Laboratory, National Oceanic and Atmospheric Administration, DOE/ID-12118, 2nd Edition, December 1, 1989.

DOE, 1995a, DOE Programmatic Spent Nuclear Fuel Management and Environmental Restoration and Waste Management Program Final EIS, DOE/EIS-02-3-F, U. S. DOE, Office of Environmental Management, Idaho Operations Office, April.

DOE-ID, 1995b, Draft Idaho National Engineering and Environmental Laboratory Cultural Resources Management Plan, DOE/ID-10361.....

DOE-ID, 1997a, Idaho Operations Office, Comprehensive Facility and Land Use Plan, DOE-ID-10514. 7

DOE-ID, 1997b, "Comprehensive Remedial Investigation Feasibility Study (RI/FS) for ICPP OU 3-13 Part A; Remedial Investigation Baseline Risk Assessment (RI/BRA) Report," DOE/ID-10534, Nov. 1997.

DOE-ID, 1997c, "Comprehensive Remedial Investigation Feasibility Study (RI/FS) for TAN OU 1-10 at INEEL,” DOE/ID-10557.

DOE-ID, 1999, Waste Area Group 5 (WAG -5) Operable Unit (OU) 5-12 Comprehensive Remedial Investigation Feasibility Study (RI/FS), DOE/ID-10607, Jan. 1999.

DOE-ID, 2000a, "Final Comprehensive Record of Decision (ROD) for Central Facilities Area (CFA) Operable Unit (OU) 4-13," DOE/ID-10719.

DOE-ID, 2000b, "Record of Decision (ROD) for Power Burst Facility Auxiliary Reactor Area (PBF/ARA) Operable Unit (OU) 5-12,” DOE/ID-10700.

EPA (U.S. Environmental Protection Agency), 1998, National Pollutant Discharge Elimination System General Permit for Storm Water Discharges from Construction Activities, 63 FR 7858 February 17, 1998.

EPA (U.S. Environmental Protection Agency), 2000, National Pollutant Discharge Elimination System Storm Water Multi-Sector General Permit for Industrial Activities, 65 FR 64746, October 30, 2000. . 48 Haney, T. J., 2000, Principal Technical Specialist, currently WAG 5 Project, INEEL .......................... 22 Hosten, P. E.; West, N. E. 1994. Cheatgrass dynamics following wildfire on a .................................... 23 Houston, D.B. 1973. Wildfires in northern Yellowstone Park. Ecology 54:1111-1117 ...................... 23 Jeppesen, D., 2001, Bureau of Land Management, Idaho Falls, ID, personal communication, November 14,2001 .

Knick, S. T. and J. T. Rotenberry. 1997. Landscape characteristics of disturbed shrubsteppe habitats in southwestern Idaho. Landscape Ecology 12: 287-297. 
Larson, D.L., W.E. Newton, P.J. Anderson, and S.J. Stein. 1999. Effects of fire retardant chemical and fire suppressant foam on shrub steppe vegetation in northern Nevada. International Journal of Wildland Fire 9(2): 114-127.

Laurance, W. F. and R. O. Bierregaard, Jr. (eds.). 1997. Tropical Forest Remnants: Ecology, Management and Conservation of Fragmented Communities. The University of Chicago Press, Chicago.

Lipp, C. D., 1994, Radiological History and Current States of Soil Contamination at the Idaho National Engineering Laboratory, INEL Engineering Design File N0. RE-22-94.

Natural Resources Defense Council. 2001. The Adverse Ecological Impacts of Roads and Logging. www.nrdc.org/land/forests/roads/summ.asp. 31,76

Noss, R.F., E.T. Laroe III, and J.M. Scott, 1995, Endangered ecosystems of the United States: a preliminary assessment of loss and degradation. U.S. Department of the Interior, National Biological Service, Biological Report 28, February. 60pp.

Oertel, C. P., and M. L, Evans, 1tr to H. D. Williams and J. A. Landis, 2000, "Results of CFA Drainfield Measurements," CPO-23-00, November 8, 2000.

Olson, G., 1996, Soil Erosion Results, Lockheed Martin Idaho Technologies Company GLO-01-96, August 6, 1996.

Overton, C.K. 1977. Description, distribution, and density of Big Lost River salmonid populations. MS Thesis, Idaho State University, Pocatello, ID. 51pp.

Patrick, S. and J. E. Anderson 1999. Fire ecology of the INEEL. Pages 66-69. in Weigmann, D. and R.D. Blew, eds. Environmental Science and Research Foundation annual technical report to DOE-ID: calendar year 1998. ESRF-033. Environmental Science and Research Foundation. Idaho Falls, ID .. 23

Primack, R. B. 1998. Essentials of Conservation Biology, Second Edition. Sinauer Associates, Inc., Sunderland, Massachusetts. $30,31,75$

Reed, R. A., J. Johnson-Barnard and W. L. Baker. 1996. Contribution of roads to forest fragmentation in the Rocky Mountains. Conservation Biology 10: 1098-1107. $31,75,76$

Reynolds, T. D., J. W. Connelly, D. K. Halford, and W. J. Arthur. 1986. Vertebrate fauna of the Idaho National Environmental Research Park. Great Basin Naturalist. 46:513-527.

Ringe, Brenda L., 1995, "Locational Analysis and Preliminary Predictive Model for Prehistoric Cultural Resources on the Idaho National Engineering and Environmental Laboratory; Master's Thesis, Idaho State University, Pocatello, ID.

Saab,V. and T.D. Rich, 1997, Large-scale conservation assessment of neotropical migratory landbirds in the Interior Columbia River Basin. USDA Forest Service, Pacific Northwest Research Station, General Technical Report. PNW-GTR-389. Portland Oregon. 31,75

Shelhas and Greenberg 1996 Landscapes. Island Press, Washington, D. C. 7

Shumar, M. L. and J. E. Anderson, 1986, Water relations of two subspecies of big sagebrush on sand dunes in southeastern Idaho. Northwest Science 60:179-185

Staley, C. S., M. J. Case, and M. L. Abbott, 2001, "Analysis of potential airborne radionuclide emissions during and after fires through SCAs on the INEEL," Engineering Design File No. EDF-1873, Rev. 0.21

Wambolt, C. L., K. S. Walhof, and M. R. Frisina. 2001. Recovery of big sagebrush communities after burning in south-western Montana. J. of Environmental Management. 61:243-252.

Watts, M. J. and C. L. Wambolt. 1996. Long-term recovery of Wyoming big sagebrush after four treatments. J. of Environmental Management. 46:95-102 …............................................................ 23

Wright, H.A. and A.W. Bailey. 1982. Fire ecology: United States and southern Canada. John Wiley and Sons, New York.

Wright, H.A., L.F. Neuenschwander, and C.M. Brighton. 1979. The role and use of fire in sagebrushgrass and pinyon-juniper plant communities: a state-of-the-art review. USDA Forest Service General Technical Report INT-58, Intermountain Forest and Range Experiment Station, Ogden, UT............. 23

Young, J. A. and R. A. Evans. 1989. Dispersal and germination of big sagebrush (Artemisia tridentata) seeds. Weed Science 37: 201-206. 
Young, J. A., and R. A. Evans, 1978, Population dynamics after wildfires in sagebrush grasslands, J. of

Range Management, 31:283-289.

23,31 


\section{GLOSSARY}

Cairns. A memorial or landmark consisting of regular or irregular piles of rock. Cairns are used as trail markers, burial markers, or to mark offerings, sacred places, or caches.

Cold-trailing. A method of controlling a partly dead fire edge by carefully inspecting and feeling with the hand for heat to detect any fire, digging out every hot spot and trenching any live edge with hand tools.

Containment lines. A fire barrier that is scraped or dug to mineral soil in order to control or 'contain' a fire.

Endangered species. A species (plant or animal) that is in danger of extinction within the foreseeable future throughout all or a significant portion of its range.

Exotic species. Non-native species often introduced by anthropogenic (or human-caused) activities and may become abundant at the expense of native species.

Lithic workshops. Discrete or large concentrations of debris created during the manufacture or maintenance of chipped stone tools. On the INEEL, this debris is primarily obsidian, with some chalcedony and chert present.

Noxious Weeds. Plant species that have been designated by law because they cause, or can cause, extraordinary negative economic and ecological impacts, and their control is unusually difficult and expensive.

PM10. Particulate matter with an aerodynamic diameter of less than or equal to $10 \mu \mathrm{m} \ldots \ldots \ldots \ldots \ldots \ldots \ldots . . . . . . . .20$

Prescribed fire. Controlled application of fire to wildland fuels to achieve a land management objective.

Sagebrush steppe ecosystem. An extensive treeless plain; commonly used when referring to the extensive sagebrush shrublands of western North America.

Soil Contamination Areas. On the INEEL there are several areas of radiologically contaminated soil, termed Soil Contamination Areas or SCAs. These areas were contaminated from past INEEL activities, usually involving liquid or airborne radioactive effluents.

Trespass. A trespass program relates to wildlands access controls to support fire management objectives, including limiting off road travel during severity conditions. At the INEEL, it means posting all of the trails as no trespassing, and keeping the unauthorized public off the site. In addition, Stage I and Stage II fire restrictions limit all field work activities to designated roads and trails.

Unwanted. Unwanted wildland fires are those wildland fires that are not burning according to a prescription.

Wet line. A line of water or water and chemical retardant, sprayed along the ground, that serves as a temporary control line from which to ignite or stop a low intensity fire.

Wildings. Individual plants that are removed from nearby plant communities and used for immediate transplanting. 


\title{
APPENDIX A - VEGETATION SURVEY
}

\section{A SURVEY OF VEGETATION RECOVERY ON WILDFIRE CONTAINMENT LINES AND AN ECOLOGICAL EVALUATION OF PRE-SUPPRESSION ${ }^{1}$ FIREBREAK CONSTRUCTION ON THE IDAHO NATIONAL ENGINEERING AND ENVIRONMENTAL LABORATORY}

\author{
Roger D. Blew, Sue Majors and Amy D. Forman \\ S.M.Stoller Corp.
}

\begin{abstract}
INTRODUCTION
Containment lines are created to separate fuel from a fire to stop its spread and to create a "safe strip" from which to start burning out fuel between the fire line and the fire (Teie 2001). Teie (2001) recommends fire lines in heavy brush have a cleared area width of 9 feet $(3 \mathrm{~m})$ with 1 to 2 feet $(0.3$ to 0.6 $\mathrm{m})$ of mineral soil exposed. Fire lines in grass fuels need to be 2 to 3 feet $(0.6$ to $0.9 \mathrm{~m})$ wide cleared to mineral soil (Teie 2001).
\end{abstract}

Firebreaks or fuel breaks are constructed as part of a fuels management program to break up large areas of fuel or to isolate a specific resource from fuel. They are strategically located areas where fuel loads have been permanently reduced (Green 1977). To be effective they require long-term maintenance.

There has been data collected on the INEEL on the recovery of vegetation following wildfire (Anderson, Patrick 2000, Blew 1999, 2000). Most sites show recovery of native perennial species, with the exception of big sagebrush (Artemisia tridentata) within the first three years. The general conclusion has been that if a healthy plant community existed before the fire, it will likely recover.

Soil disturbance associated with a fire can reduce the potential for successful recovery. Ratzlaff and Anderson (1995) reported that the soil disturbance associated with drilling seed into a recently burned area near Pocatello, ID slowed recovery. Blew $(1997,1998,1999)$ reported similar results for soil disturbances associated with reseeding burns on the INEEL. No data on the direct effects of constructing containment lines or firebreaks without follow-up vegetation management have been reported for eastern Idaho.

This study was conducted to provide site-specific information on the impact of pre-suppression and suppression activities on ecological resources of the INEEL. Specific objectives included:

- Determining the effect of containment line construction on recovery of native vegetation following fire. Both the effect of blading the containment line and the effect of not re-contouring the soil ricks was addressed.

- Evaluate the ecological effects of the construction of pre-suppression firebreaks.

\section{METHODS}

Containment Lines

Containment lines around fires were surveyed for species density, frequency, and cover. Four fires were selected for surveys. In each fire, five sampling sites were established. At each site, 50-m long transects were established in the center of the containment line, both soil ricks on the margins of the containment line and nearby in the burned area. Both soil ricks were sampled in case there were differences between the rick on the windward side and the one on the lee side. It was hypothesized that the ricks would be

\footnotetext{
${ }^{1}$ Referred to as pre-fire in the main body of the EA.
} 
suitable sites for windblown seed to be deposited and that more seed might be deposited on the windward rick. Rick height was measured at along transect at 5-m intervals.

Ten $0.5-\mathrm{m}^{2}$ quadrats were read for density and frequency. Density is the number of individuals in a 1.0$\mathrm{m} 2$ area. Frequency is the proportion of plots in which a particular species was found. The ten quadrats were placed at 5-m intervals along the transect.

Cover was determined by line intercept along the 50-m transect. Cover was determined for perennials only, because most of the annual species had senesced before the sample was completed. Including them would have provided an inaccurate estimate of their cover. Density and frequency are suitable measures of their presence in the plant community. Cover is not reported for the soil ricks because of interferences from individuals not located on the ricks. There was significant overlap of especially shrubs from off of the rick, because the ricks are relatively narrow. This made interpreting this data problematic. Density and frequency calculated from the quadrat data adequately describes the plant community directly affected by deposition of the soil rick.

Data analysis was by paired analysis. Most analyses were by paired t-test. Some data required log or arcsine transformations to meet assumptions for normality and equal variances. One comparison (cheatgrass in the leeward rick vs. the burn) required the non-parametric Wilcoxon Sign-Rank test because the data did not meet normality assumptions. Transformations did not correct the deficiencies.

Interpretations of traditional statistical approaches require the data supply evidence that a treatment mean is significantly different from the control mean. The determination of suitable statistical evidence is usually based on an acceptable error rate of $5 \%$. In other words, only $5 \%$ of the time will the means be found to be different when in fact they are the same. This kind of error is referred to as a Type I error, or a false change error. The acceptable error rate (usually less than 5\%) is called a and is designated as a $<$ 0.05. If the data do not supply that evidence, the means are considered to be equivalent.

The precautionary principle is often used to determine if a disturbed area has returned to a pre-disturbance condition (Elzinga, et. al 1998, Manly, 2000). Using the precautionary principle, the data must not only be able to demonstrate a difference between the treatment mean and the control mean (based on a), it must also be able to supply direct evidence that the two means are equivalent. This evidence is also based on an acceptable error rate. In this case, however, the error of concern is determining that no difference between means exists when in fact the means are different. This is called a Type II error, or a missed change error. This error rate is called $B$. The usually accepted Type II error rate is less than $20 \%$, designated as $\beta<0.20$. When the statistical results show that $\beta<0.20$, it provides greater confidence that the test has sufficient power to conclude that the two means are, in fact, the same.

The rule-set used to interpret the statistical results is based on interpreting both Type I and Type II error rates. If the results of a test show that a $<0.05$, then it can be concluded that the treatment mean (containment line or soil ricks) is significantly different from the control mean (burn transect). If the results of a test show that $\mathrm{a}>0.05$, but $\beta<0.20$, then we can conclude that the treatment mean is equal to the control mean. However, if the results of a test show that $a>0.05$ and $\beta>0.20$, then we do not have sufficient evidence to conclude that the treatment mean and control mean is equal, nor can we conclude that they are they different. In this case, the precautionary principle recommends that we cannot consider the two to be equal. See Green (1994) for additional discussion on this approach.

Firebreaks

Recently constructed firebreaks and other fuel management areas were mapped using GPS. The mapping was done by driving or walking down the center of the firebreak. As the features were being mapped, observations on the condition of the fuel break, the cover on the firebreak, the length and width of the 
firebreak, etc. were also noted. This information was used to recommend management needs for maintaining the firebreaks and fuel management areas, and evaluate their potential impact to ecological resources.

\section{RESULTS AND DISCUSSION}

Containment Lines

The containment lines surveyed ranged in width 3.25 to $9.3 \mathrm{~m}$ (10.5 to $30.5 \mathrm{ft})$. Figures A-1 and A-2 show containment lines constructed in 1999 (Figure A-1) and 1995 (Figure A-2) that illustrates their typical structure. Note in Figure A-1 the relatively large soil rick on the right-hand side, relatively deep cut on the left-hand side, and the generally poor recovery of native grasses and shrubs. Figure A-2 shows containment lines built in 1995 that burned over again in 1999. Note the generally inconspicuous soil ricks (suggesting only shallow soil disturbance) and strong recovery of native perennial grasses. These two figures demonstrate the range of conditions found on containment lines during this survey.

Cheatgrass density was generally lower on the burn transects than on the containment line or on the soil ricks (Table A-1). The Butte City fire is a notable exception. Interpreting the statistical results using the precautionary principle leads to a conclusion that the cheatgrass densities on the containment lines and the soil ricks was not the same as on the burn and were likely higher. The frequency that cheatgrass occurred was also generally lower in the burn than on the containment line than on the undisturbed, burned area (Table A-1). Because a $<0.05$, we can conclude that the frequency of cheatgrass on the containment line and soil ricks is significantly higher than on the undisturbed burned area (Table A-1).

It is generally considered that soil disturbance is one of the key factors allowing cheatgrass invasion and dominance on a site. Cheatgrass invasion is likely the single most important factor in loss of sagebrush steppe habitat. Cheatgrass provides an important "flash fuel" that provides both an important ignition fuel and a rapid rate of spread. Fire tends to re-enforce the dominance of cheatgrass on a site by altering the fire return interval. Instead of areas burning once every 50 to 100 years or more, with cheatgrass dominance they will burn every 3 to 5 years. This provides too little time for most native species, especially sagebrush to recover. The results of this study suggest that cheatgrass may find the containment lines and the soil ricks a more favorable place to gain dominance than the undisturbed burned areas.

The presence and dominance of perennial grasses is an important indicator of the recovery status of vegetation following fire or other disturbances. Perennial grass density (Table A-2) on the burned transects (62.7) was more than double that found on the containment line (26.4) or either soil rick (21.1 and 17.5). Because a $<0.05$ for all of the pair wise comparisons, we can conclude that the cover by perennial grasses is significantly higher on the burned area than on the containment lines or soil ricks. Cover by perennial grasses was also twice as high on the burned area as on the containment lines (Table A-2).

The perennial grasses are generally the first native species to recover following a fire. Along with the shrubs capable of re-sprouting following fire, the grasses provide the primary means of minimizing soil erosion. There is usually sufficient cover by perennial grasses to limit blowing dust the first year after a wildfire. The successful recovery of the grasses is also important for competing against invasive species like cheatgrass and limits their spread into, and dominance of, the burned area.

The results for density of non-native forbs showed means for the containment lines and the soil ricks were higher than that in the burned area (Table A-3). Using the precautionary principle, we conclude that a non-native forbs density on the containment line and the soil ricks is not the same as the burn and may be higher. This group of plants includes desert alyssum, Russian thistle, kochia, and tumble mustard. These 
species are typical invaders of disturbed areas. They re-enforce the process of increased fire frequency typical of areas invaded by the annual, non-native grass, cheatgrass.

The results for density of native forbs was not as expected. The statistical results suggest that the means from the containment lines and the soil ricks are not equal to that in the burned areas (Table A-4). Mean densities for the containment line and soil ricks were generally higher than that found on the burned area.

The native forbs, or wildflowers, are important to the biodiversity of the sagebrush steppe. This group includes many leguminous species that may provide an important input of nitrogen to this ecosystem. Many of these forbs are also an important food source for some sagebrush steppe wildlife. Significant among them is sage grouse. Sage grouse chicks require forbs as an important part of their summer diet.

Another invasive species of concern on portions of the INEEL is halogeton (Halogeton glomeratus). Halogeton is commonly found on areas that have been severely disturbed and is generally isolated to those habitats. It was found at six of the twenty sampling sites in this study (Table A-5). The containment line in Figure A-1 was one of those sites. It was found on the burned transect at only two sites. Because halogeton was not likely to be found at all sampling sites, statistical analysis only included those sites where it was found in this study.

Halogeton densities and frequencies were generally higher on the containment lines and soil ricks than on the burned areas (Table A-6). The interpretation of the statistical results suggest the disturbed transects are not equivalent to the burned transects. Halogeton is an invasive species that has historically been an important concern for range managers in the sagebrush steppe ecosystem. Halogeton is poisonous to sheep and it is difficult to control once it gets started.

Because of the range of conditions the containment lines were found in, it will likely be necessary to inventory most of the length of each line to determine which parts of, and to what extent, the containment lines need rehabilitation. As shown in this study, there are areas at risk to invasion and domination by cheatgrass, halogeton and other non-native plants. These areas should be identified and a weed management plan developed and implemented. Those areas found to have inadequate recovery of native perennial species should have revegetation plans developed and implemented. These plans should include re-contouring the soil ricks.

In order to reduce the expense of restoration on containment lines constructed in the future, guidelines should be developed to control the methods used to construct containment lines including their width and the depth of soil removed. Some of the expense of restoration could be eliminated by developing guidelines for where containment lines should, or should not, be constructed. For example, a containment line was constructed that parallels a wide gravel road, T-12 (Figure A-3) for several miles rather than using the road as an anchor point (Teie 2001).

Firebreaks

Twenty-four firebreaks were surveyed as part of this study (Table A-6). The locations of the surveyed firebreaks are shown in Figure A-4. The total length of pre-suppression firebreaks constructed during 2000 and 2001 was approximately 63,000 m (39 miles)(Table A-6). The firebreaks ranged from 4 to 17 meters (13 to 56 feet in width)(Table A-6). Some of the firebreaks were covered by gravel as part of the construction. Others were left as bare soil.

The firebreaks surveyed ranged from 5 to $17 \mathrm{~m}$ (16 to 56 feet) in width. One criticism of pre-suppression firebreaks is that they generally cannot stop a head fire under extreme conditions (Countryman 1974 and Green 1977). Countryman (1974) noted this to be true of firebreaks even 100 to 400 feet wide in chaparral vegetation. 
Fourteen of the firebreaks surveyed had burnable vegetation, primarily sagebrush, on both sides of the firebreak. Some of these firebreaks are a considerable distance from the nearest facility. For example, the individual facilities that make up Power Burst Facility (PBF) are an average of $500 \mathrm{~m}$ (1650 ft) from the firebreak constructed outside of the perimeter fence.

At some facilities, firebreaks were constructed in areas with minimal burnable vegetation. Examples include the Specific Manufacturing Capability (SMC) North Perimeter Fence and TAN (NE corner to T28), which are in playa, salt desert shrub or grassland. In at least one case, the Experimental Field Station, firebreak construction destroyed crested wheatgrass green-strips.

As mentioned previously, soil disturbance is one of the key factors allowing cheatgrass invasion and dominance on a site. Because cheatgrass plays such an important role in loss of sagebrush habitat, developing long-term maintenance plans for these firebreaks is critical. Each firebreak should be reevaluated for its strategic role in a broader fire management plan. Those that are deemed useful should have a long-term maintenance plan developed and a commitment for funding the plan obtained. If the firebreak is determined to not have a place in the strategic plan or if long-term funding cannot be secured, the firebreaks should be restored to the pre-existing vegetation type.

\section{LITERATURE CITED}

Anderson, J.E. and S.M. Patrick. 2000. Fire ecology of the INEEL. Pages 91-93. in A. Luft and R.W. Warren, eds. Environmental Science and Research Foundation annual technical report to DOE-ID: calendar year 1999. ESRF-33. Environmental Science and Research Foundation, Idaho Falls, ID.

Blew, R.D. and K.C. Jones. 1998. Planting and irrigating influence on post-fire vegetation recovery. Pages 94-95. in Reynolds, T.D. and R.W. Warren, eds. Environmental Science and Research Foundation annual technical report to DOE-ID: calendar year 1997. ESRF-27. Environmental Science and Research Foundation, Idaho Falls, ID.

Blew, R.D. 1999. Planting and irrigating effects on vegetation recovery from fire. Pages 70-71. in Weigmann, D. and R.D. Blew, eds. Environmental Science and Research Foundation annual technical report to DOE-ID: calendar year 1998. ESRF-033. Environmental Science and Research Foundation. Idaho Falls, Idaho.

Blew, R.D. 2000. Planting and irrigating effects on vegetation recovery from fire. Pages 89-90. in A. Luft and R.W. Warren, eds. Environmental Science and Research Foundation annual technical report to DOE-ID: calendar year 1999. ESRF-33. Environmental Science and Research Foundation, Idaho Falls, ID.

Countryman, C.M. 1974. Can southern California wildfire conflagrations be stopped? USDA Forest Service General Technical Report PSW-7. USDA Forest Service, Berkeley, CA. 11p.

Elzinga, C.L., D.W. Salzer, and J.W. Willoughby, 1998. Measuring and Monitoring Plant Populations. BLM Technical Reference 1730-1. U.S. Department of Interior, Bureau of Land Management, Denver. $477 \mathrm{p}$.

Green, L.R. 1977. Fuel breaks and other fuel modification for wildland fire control. Agriculture Handbook No. 499. USDA Forest Service. 79p. 
Green, R.H. 1994. Aspects of power analysis in environmental sampling. Pages 173 to 182. in, Fletcher, D.J. and B.F.J. Manly, eds. Statistics in Environmental Monitoring. Otago Conference Series No. 2. Univeristy of Otago Press, Dunedin,

Manly, B.F.J. 2001. Statistics for Environmental Science and Management. Chapman \&Hall/CRC. 326 p.

Patrick, S. and J.E. Anderson. 1999. Fire ecology of the INEEL. Pages 66-69. in Weigmann, D. and R.D. Blew, eds. Environmental Science and Research Foundation annual technical report to DOE-ID: calendar year 1998. ESRF-033. Environmental Science and Research Foundation. Idaho Falls, Idaho.

Ratzlaff, T.D. and J.E. Anderson. 1995. Vegetal recovery following wildfire in seeded and unseeded sagebrush steppe. Journal of Range Management. 48:386-391.

Teie, W.C. 2001. Firefighter's handbook on wildland firefighting: strategy, tactics and safety. Deer Valley Press. Rescue, California. 330p. 
Table A-1. Mean density and frequency of cheatgrass on each transect type for each fire sampled. Statistical results are for paired t-tests comparing disturbed transects to the burn.

\begin{tabular}{|c|c|c|c|c|c|c|c|c|}
\hline \multirow[b]{2}{*}{ Fire } & \multirow[b]{2}{*}{ Burn } & \multicolumn{3}{|c|}{ Density (plants $/ \mathrm{m}^{2}$ ) } & \multicolumn{4}{|c|}{ Frequency } \\
\hline & & $\begin{array}{c}\text { Containment } \\
\text { Line }\end{array}$ & $\begin{array}{l}\text { Leeward } \\
\text { Soil Rick }\end{array}$ & $\begin{array}{c}\text { Windward } \\
\text { Soil Rick }\end{array}$ & Burn & $\begin{array}{c}\text { Containment } \\
\text { Line }\end{array}$ & $\begin{array}{l}\text { Leeward } \\
\text { Soil Rick }\end{array}$ & $\begin{array}{c}\text { Windward } \\
\text { Soil Rick }\end{array}$ \\
\hline Butte City & 34.3 & 25.0 & 58.8 & 32.9 & 0.32 & 0.42 & 0.44 & 0.44 \\
\hline 1995/1999 & 27.8 & 38.7 & 32.2 & 60.1 & 0.50 & 0.66 & 0.64 & 0.72 \\
\hline 1999 & 8.9 & 5.4 & 6.7 & 31.6 & 0.22 & 0.28 & 0.28 & 0.62 \\
\hline Tin cup & 19.5 & 52.0 & 137.2 & 22.4 & 0.42 & 0.52 & 0.52 & 0.56 \\
\hline Overall Mean & 22.6 & 30.3 & 58.7 & 36.7 & 0.36 & 0.47 & 0.47 & 0.585 \\
\hline \multirow{2}{*}{$\begin{array}{l}\text { Statistical } \\
\text { Results }\end{array}$} & a & 0.189 & 0.182 & 0.015 & & 0.004 & 0.012 & $<0.0001$ \\
\hline & B & 0.911 & 0.818 & 0.348 & & 0.353 & NA & 0.020 \\
\hline
\end{tabular}

Table A-2. Mean density and cover of native perennial grasses and sedges on each transect type for each fire sampled. Cover reported only for the burn and the containment line. Statistical results are for paired $\mathrm{t}$-tests comparing disturbed transects to the burn.

\begin{tabular}{|c|c|c|c|c|c|c|}
\hline \multirow[b]{2}{*}{ Fire } & \multirow[b]{2}{*}{ Burn } & \multicolumn{3}{|c|}{ Density (plants $/ \mathrm{m}^{2}$ ) } & \multicolumn{2}{|c|}{ Cover (\%) } \\
\hline & & $\begin{array}{l}\text { Containment } \\
\text { Line }\end{array}$ & $\begin{array}{c}\text { Leeward } \\
\text { Soil Rick }\end{array}$ & $\begin{array}{c}\text { Windward } \\
\text { Soil Rick }\end{array}$ & Burn & $\begin{array}{c}\text { Containment } \\
\text { Line }\end{array}$ \\
\hline Butte City & 80.3 & 34.6 & 12.2 & 21.1 & 3.8 & 3.0 \\
\hline 1995/1999 & 99.5 & 30.6 & 36.5 & 17.7 & 4.2 & 1.8 \\
\hline 1999 & 49.5 & 30.3 & 19.5 & 18.8 & 4.4 & 0.6 \\
\hline Tin cup & 21.3 & 9.9 & 16.0 & 12.5 & 2.7 & 0.8 \\
\hline Overall Mean & 62.7 & 26.4 & 21.1 & 17.5 & 3.8 & 1.6 \\
\hline \multirow[t]{2}{*}{ Statistical Results } & a & 0.016 & $<0.001$ & 0.003 & & $<0.001$ \\
\hline & B & 0.353 & 0.040 & 0.114 & & 0.004 \\
\hline
\end{tabular}


Table A-3. Mean density of non-native forbs on each transect type for each fire sampled. Statistical results are for paired t-tests comparing disturbed transects to the burn.

\begin{tabular}{|c|c|c|c|c|}
\hline \multirow[b]{3}{*}{ Fire } & \multicolumn{4}{|c|}{ Density (plants $/ \mathrm{m}^{2}$ ) } \\
\hline & & & Leeward & Windward \\
\hline & Burn & Containment Line & Soil Rick & Soil Rick \\
\hline Butte City & 26.9 & 36.9 & 16.6 & 28.3 \\
\hline 1995/1999 & 9.56 & 24.1 & 24.0 & 35.4 \\
\hline 1999 & 2.02 & 13.9 & 5.64 & 9.2 \\
\hline Tin cup & 5.1 & 47.6 & 60.6 & 27.3 \\
\hline Overall Mean & 10.9 & 30.6 & 26.7 & 25.1 \\
\hline \multirow[t]{2}{*}{ Statistical Results } & a & 0.071 & 0.102 & 0.086 \\
\hline & B & 0.674 & 0.750 & 0.715 \\
\hline
\end{tabular}

Table A-4. Mean density of native forbs on each transect type for each fire sampled. Statistical results are for paired t-tests comparing disturbed transects to the burn.

\begin{tabular}{lcccc}
\hline & \multicolumn{4}{c}{ Density $\left(\right.$ plants $\left./ \mathrm{m}^{2}\right)$} \\
\cline { 2 - 5 } Fire & Burn & Containment Line & Leeward & Windward \\
\hline Butte City & 3.4 & 3.6 & 4.5 & Soil Rick \\
$1995 / 1999$ & 2.0 & 4.3 & 4.0 & 10.4 \\
1999 & 4.4 & 11.1 & 8.0 & 4.3 \\
Tin cup & 8.0 & 10.1 & 3.0 & 5.4 \\
\hline Overall Mean & 4.4 & 7.3 & 4.9 & 6.0 \\
\hline \hline & & 0.100 & 0.793 & 0.266 \\
Statistical Results & $\mathrm{a}$ & 0.746 & 0.950 & 0.921 \\
\hline
\end{tabular}


Table A-5. Mean density and frequency of halogeton on each transect type for each site sampled. Statistical results* are for paired t-tests comparing disturbed transects to the burn.

\begin{tabular}{|c|c|c|c|c|c|c|c|c|c|}
\hline \multirow[b]{2}{*}{ Fire } & \multirow[b]{2}{*}{ Site } & \multicolumn{4}{|c|}{ Density (plants $/ \mathrm{m}^{2}$ ) } & \multicolumn{4}{|c|}{ Frequency } \\
\hline & & Burn & $\begin{array}{c}\text { Containment } \\
\text { Line }\end{array}$ & $\begin{array}{l}\text { Leeward } \\
\text { Soil Rick }\end{array}$ & $\begin{array}{c}\text { Windward } \\
\text { Soil Rick }\end{array}$ & Burn & $\begin{array}{l}\text { Containment } \\
\text { Line }\end{array}$ & $\begin{array}{l}\text { Leeward } \\
\text { Soil Rick }\end{array}$ & $\begin{array}{c}\text { Windward } \\
\text { Soil Rick }\end{array}$ \\
\hline Butte City & old highway & 0 & 0 & 0 & 0 & 0 & 0 & 0 & 0 \\
\hline Butte City & $\mathrm{t} 11$ & 0 & 0 & 0 & 0 & 0 & 0 & 0 & 0 \\
\hline Butte City & t3 & 0 & 0 & 0 & 0 & 0 & 0 & 0 & 0 \\
\hline Butte City & t5 & 0 & 0 & 0 & 0 & 0 & 0 & 0 & 0 \\
\hline Butte City & tower road & 0 & 0 & 0 & 0 & 0 & 0 & 0 & 0 \\
\hline 1995/1999 & t22 bottom & 0 & 0 & 0 & 0 & 0 & 0 & 0 & 0 \\
\hline 1995/1999 & t22 hilltop & 0 & 0 & 0 & 0 & 0 & 0 & 0 & 0 \\
\hline $1995 / 1999$ & t22 north & 0 & 0 & 0 & 0 & 0 & 0 & 0 & 0 \\
\hline $1995 / 1999$ & t22 south & 0.2 & 2.6 & 4.4 & 7.6 & 0.1 & 0.2 & 0.3 & 0.7 \\
\hline $1995 / 1999$ & $\mathrm{t} 23$ & 0 & 43.6 & 19 & 0 & 0 & 0.3 & 0.7 & 0 \\
\hline 1999 & $\mathrm{t} 20$ & 0 & 0 & 0.2 & 0 & 0 & 0 & 0.1 & 0 \\
\hline 1999 & $\mathrm{t} 22$ & 0 & 60.6 & 14.6 & 14.8 & 0 & 0.7 & 0.5 & 0.4 \\
\hline 1999 & $\mathrm{t} 25$ & 0 & 0 & 0 & 0 & 0 & 0 & 0 & 0 \\
\hline 1999 & $\mathrm{t} 4$ & 0 & 0 & 0 & 0 & 0 & 0 & 0 & 0 \\
\hline 1999 & $\mathrm{t} 7$ & 3.4 & 1.4 & 3.2 & 0 & 0.6 & 0.5 & 0.3 & 0 \\
\hline Tin cup & old highway & 0 & 0 & 0 & 0 & 0 & 0 & 0 & 0 \\
\hline Tin cup & $\mathrm{t} 12$ & 0 & 0 & 0 & 0 & 0 & 0 & 0 & 0 \\
\hline Tin cup & $\mathrm{t} 2$ & 0 & 0 & 0 & 0 & 0 & 0 & 0 & 0 \\
\hline Tin cup & t3 & 0 & 0 & 0 & 0 & 0 & 0 & 0 & 0 \\
\hline Tin cup & TRA & 0 & 1.2 & 0.6 & 0 & 0 & 0.2 & 0.1 & 0 \\
\hline Means * & & 0.6 & 18.2 & 7.0 & 3.7 & 0.12 & 0.32 & 0.33 & 0.18 \\
\hline \multirow{2}{*}{\multicolumn{2}{|c|}{ Statistical Results* }} & $a$ & 0.174 & 0.118 & 0.306 & & 0.145 & 0.189 & 0.709 \\
\hline & & $\beta$ & 0.834 & 0.751 & 0.928 & & 0.795 & 0.849 & 0.950 \\
\hline
\end{tabular}

${ }^{*}$ Means and statistical analysis included only those sites with recorded occurrence of halogeton. See text for details. 
Table A-6. Attributes of recently constructed firebreaks constructed on the INEEL.

\begin{tabular}{|c|c|c|c|c|}
\hline Firebreak Location & Width (m) & Ground Cover & Length $(\mathrm{m})$ & Vegetation Type \\
\hline WRRTF & 7 & bare soil & 1,524 & $\begin{array}{l}\text { Sagebrush/Rabbitbrush and Salt Desert Shrub } \\
\text { both sides }\end{array}$ \\
\hline CFA 689 & 5 & bare soil & 210 & $\begin{array}{l}\text { Sagebrush Steppe outside } \\
\text { Facility inside }\end{array}$ \\
\hline EBR-I Perimeter Fence & 17 & gravel & 1.098 & $\begin{array}{l}\text { Sagebrush Steppe outside } \\
\text { Replanted Sagebrush Steppe Inside }\end{array}$ \\
\hline EBR-I T-road & 6 & bare soil & 1,812 & Sagebrush Steppe both sides \\
\hline RWMC Flood Control Channel & 5 & bare soil & 2,559 & Sagebrush Steppe both sides \\
\hline $\begin{array}{l}\text { Experimental Field Station (road to precipitation } \\
\text { sampling station) }\end{array}$ & 5 & bare soil & 345 & Crested Wheatgrass both sides \\
\hline Experimental Field Station (road to caissons) & 4 & bare soil & 87 & Sagebrush Steppe both sides \\
\hline $\begin{array}{l}\text { Experimental Field Station (lawn around storage } \\
\text { shed) }\end{array}$ & 11 & bare soil & 121 & $\begin{array}{l}\text { Crested Wheatgrass outside } \\
\text { Facility inside }\end{array}$ \\
\hline Experimental Field Station (entrance road) & 13 & bare soil & 139 & $\begin{array}{l}\text { Sagebrush Steppe/Crested Wheatgrass } \\
\text { outside } \\
\text { Gravel Road inside }\end{array}$ \\
\hline PBF Perimeter Fence & 6 & bare soil & 6,933 & Sagebrush Steppe both sides \\
\hline CFA Fire Station Propane Tank & 12 & gravel & 120 & $\begin{array}{l}\text { Sagebrush Steppe outside } \\
\text { Facility inside }\end{array}$ \\
\hline Mercury Retort Area Perimeter Fence & 12 & bare soil & 564 & $\begin{array}{l}\text { Sagebrush Steppe outside } \\
\text { Facility Fence inside }\end{array}$ \\
\hline RESL to Medical Center (road) & 10 & gravel & 265 & Sagebrush Steppe both sides \\
\hline East Side of Railroad & 5 & gravel & 13,875 & $\begin{array}{l}\text { Sagebrush Steppe outside } \\
\text { Railroad inside }\end{array}$ \\
\hline West Side of Railroad & 5 & gravel & 14,697 & $\begin{array}{l}\text { Sagebrush Steppe outside } \\
\text { Railroad inside }\end{array}$ \\
\hline T-4, U.S. 26 to Middle Butte Fire & 5 & bare soil & 3,244 & Sagebrush Steppe both sides \\
\hline TAN (NE corner to T-28) & 10 & bare soil & 3,118 & Salt Desert Shrub and Grassland both sides \\
\hline SMC North Perimeter Fence & 7 & bare soil & 866 & $\begin{array}{l}\text { Playa outside } \\
\text { Facility inside }\end{array}$ \\
\hline TAN North Perimeter Fence & 6 & bare soil & 390 & $\begin{array}{l}\text { Sagebrush/Rabbitbrush and Salt Desert Shrub } \\
\text { outside } \\
\text { Facility inside }\end{array}$ \\
\hline SL-1.Perimeter, Inside & 8 & bare soil & 1,842 & Sagebrush Steppe both sides \\
\hline SL-1.Perimeter, Outside & 6 & bare soil & 2,377 & Sagebrush Steppe both sides \\
\hline SL-1 Entrance Road & 6 & bare soil & 202 & Sagebrush Steppe both sides \\
\hline NRF to TRA & 6 & bare soil & 4,604 & Sagebrush Steppe both sides \\
\hline \multirow[t]{2}{*}{ TRA to CFA } & 12 & bare soil & 1,883 & Sagebrush Steppe both sides \\
\hline & & Total Length & 62,875 & \\
\hline
\end{tabular}




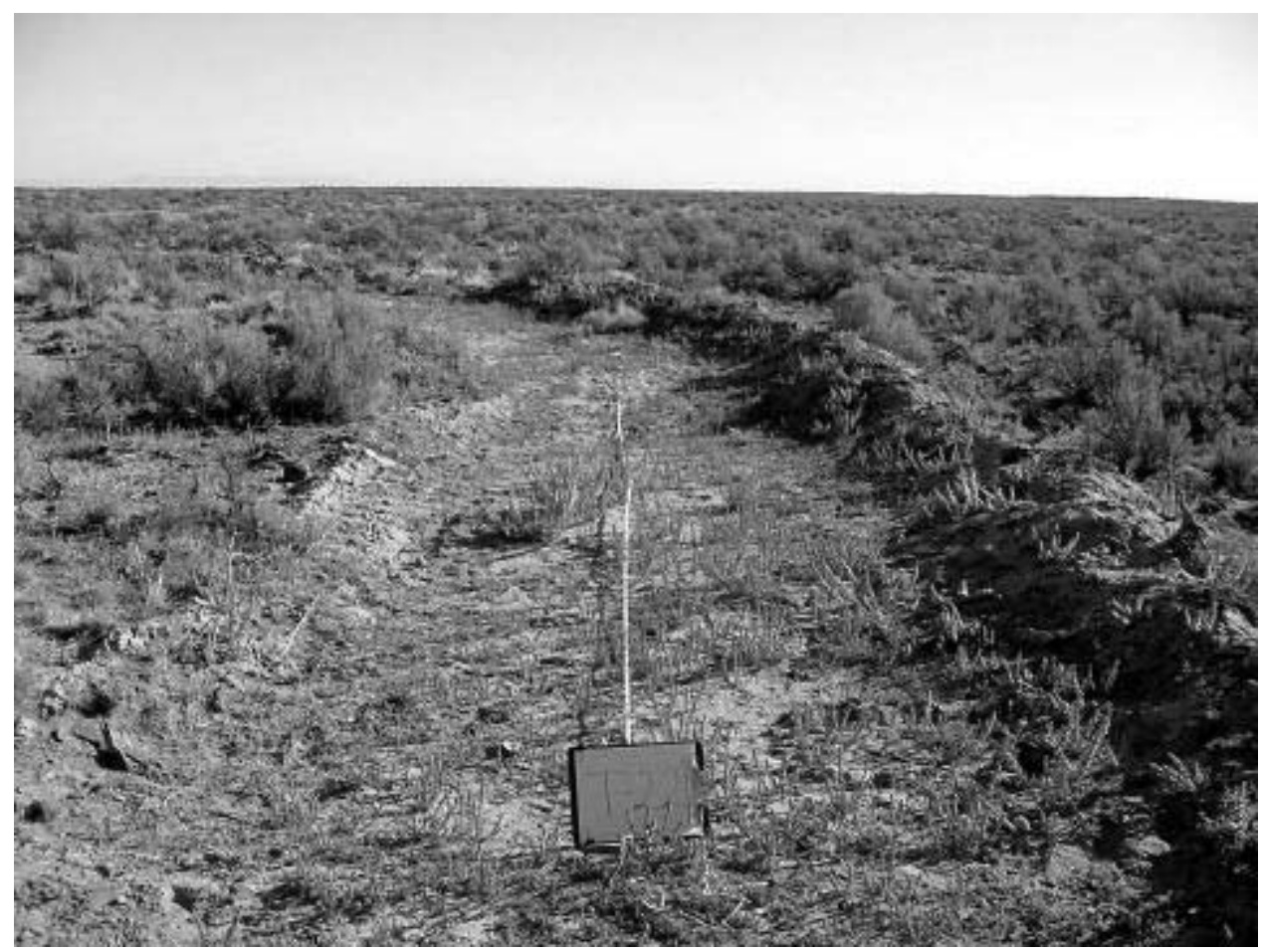

Figure A-1. Containment line showing larger soil ricks and little recovery of native perennial vegetation.

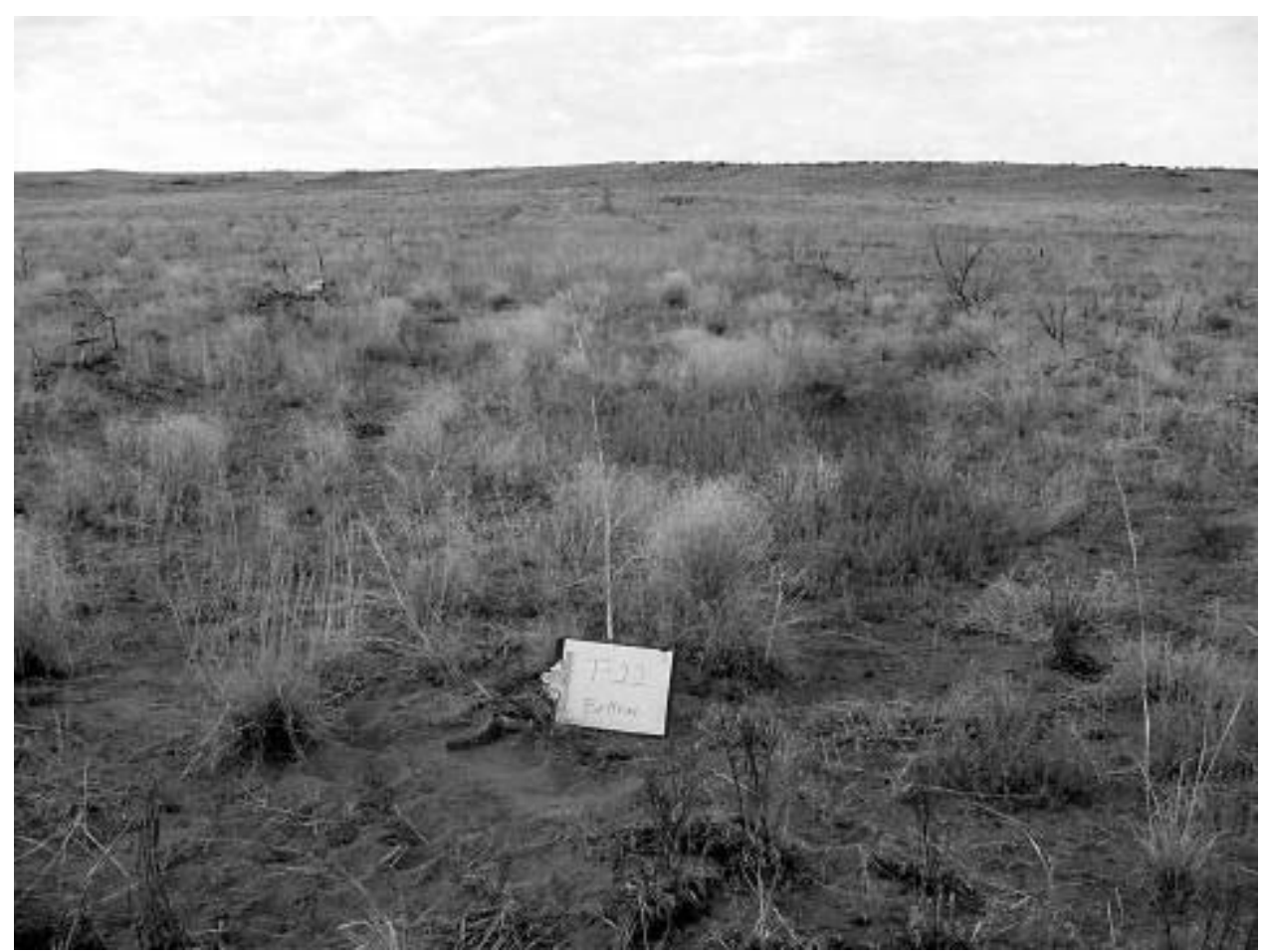

Figure A-2. Containment line showing good recovery of native perennial grasses. Note soil ricks are inconspicuous. 


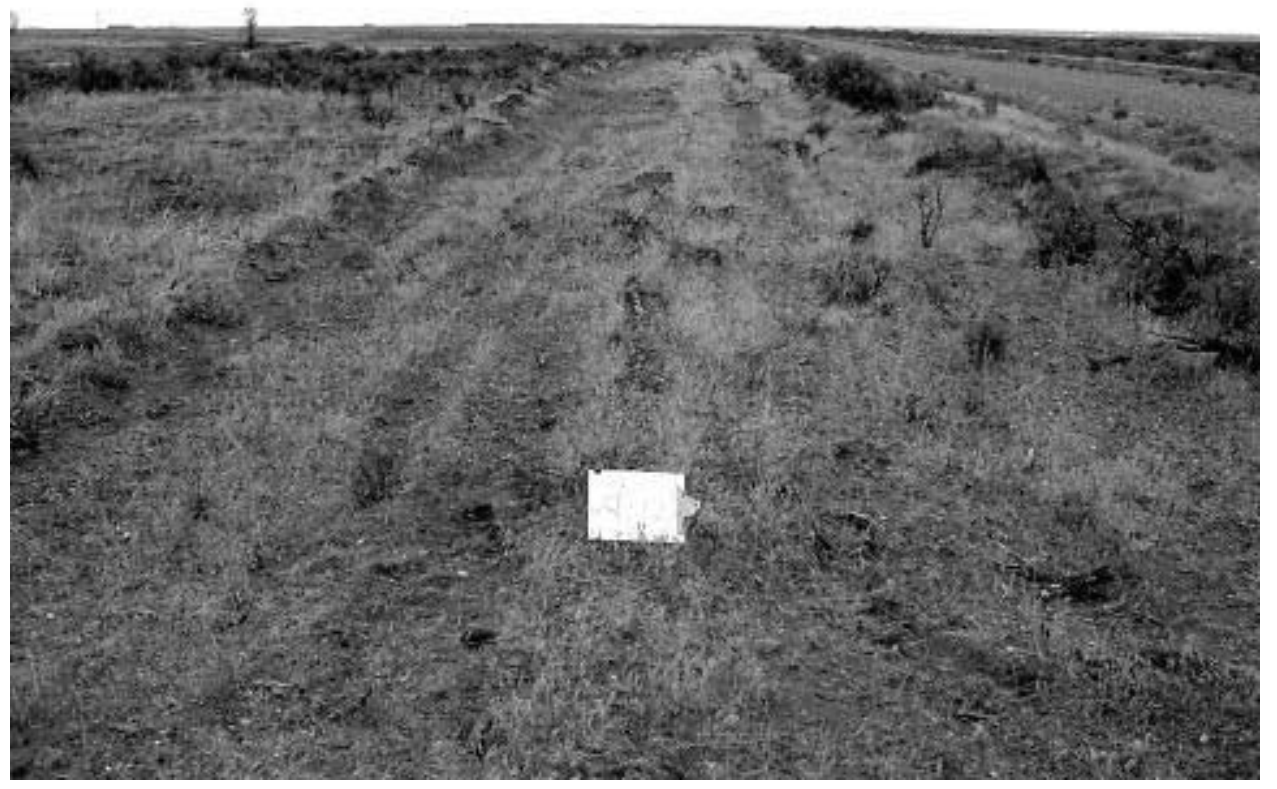

Figure A-3. Containment line paralleling graveled, road T-12. 


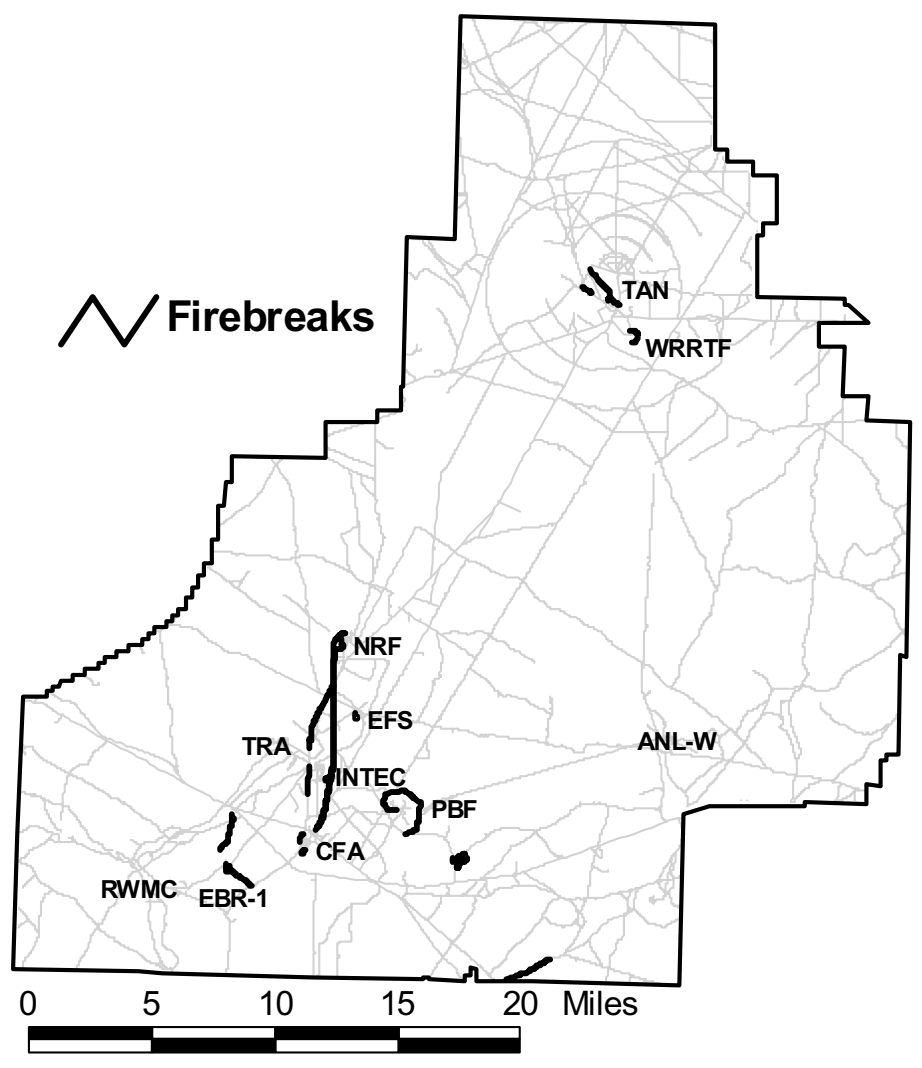

Figure A-4. Locations of recently constructed firebreaks on the INEEL. 


\section{APPENDIX B - MANAGEMENT GOALS}

Section 3.1 provides the INEEL specific management goals and objectives for the INEEL Infrastructure, Fire Department and Fire Marshall organizations and for those objectives and goals for air, water, wildlife/habitat, and cultures resources. Section 4 provides a comparison of management goals for each alternative. The following table (Table B-1) gives a more detailed description and comparison of wildland fire management objectives and goals. 


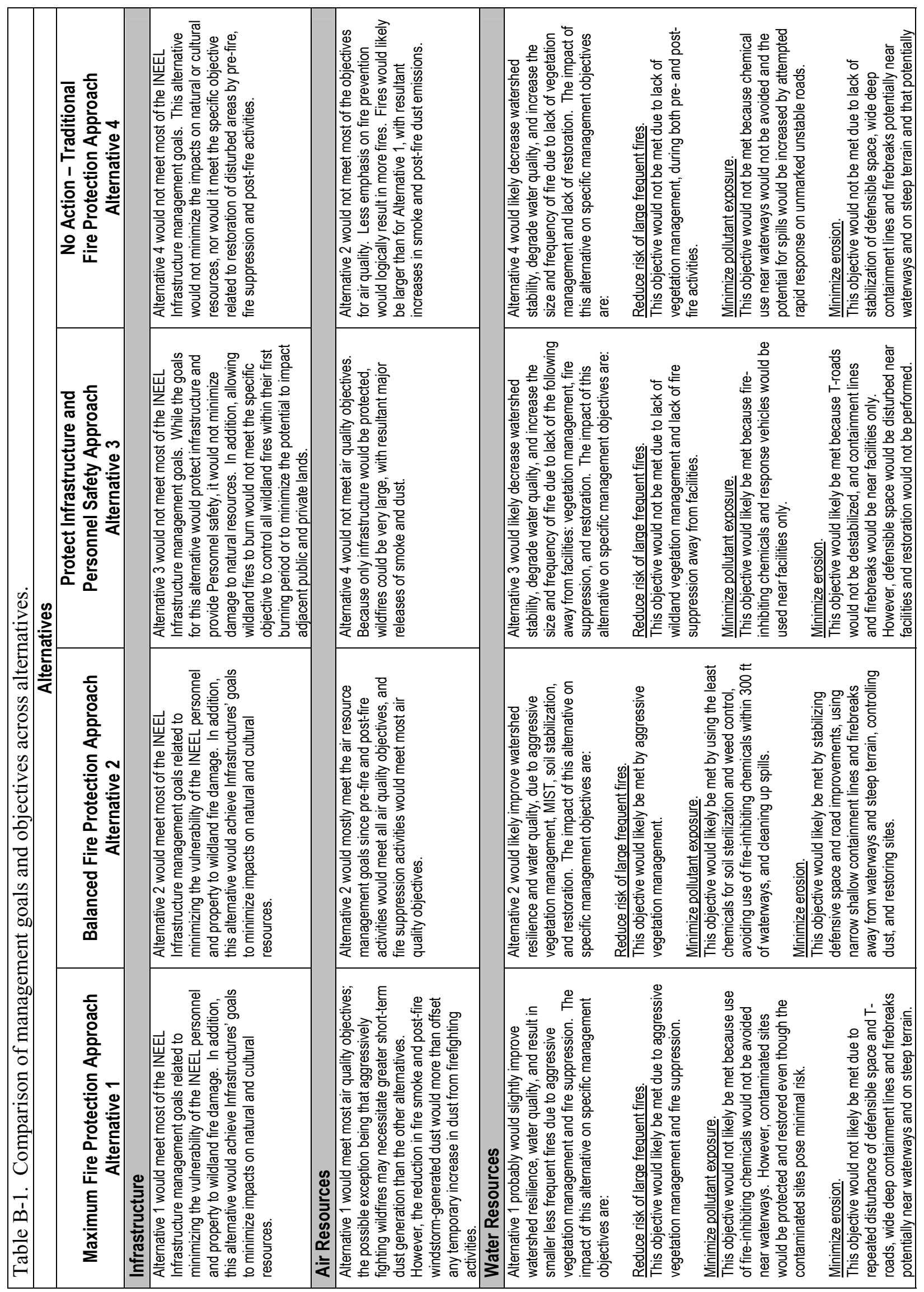




\begin{tabular}{|c|c|c|c|c|c|c|c|c|c|}
\hline & 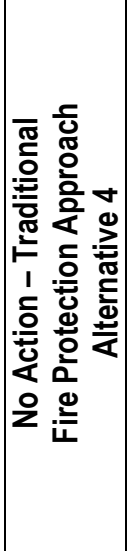 & 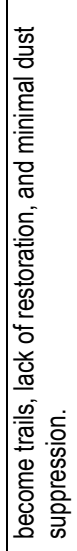 & 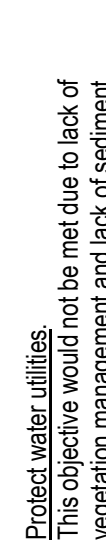 & & 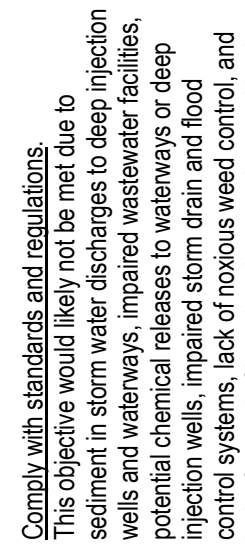 & 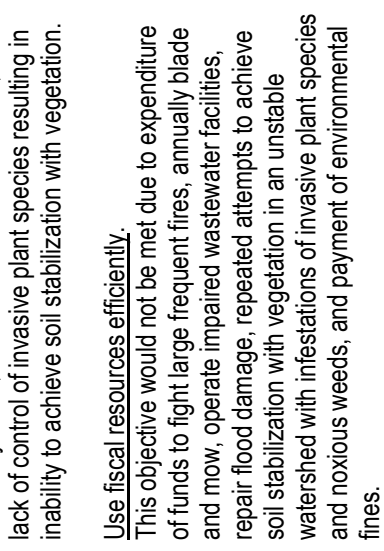 & & 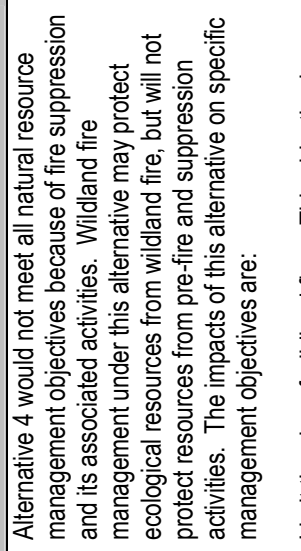 & 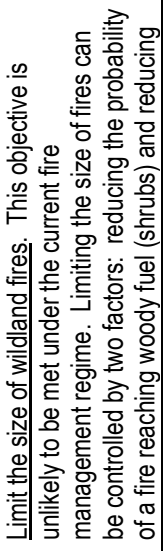 \\
\hline & 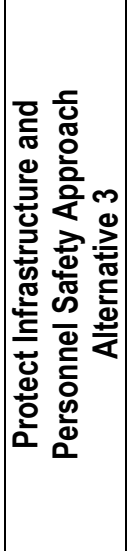 & & 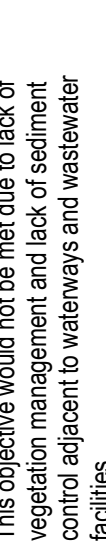 & & 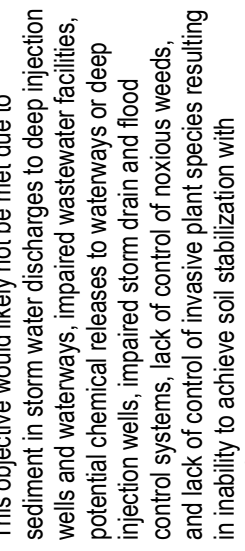 & 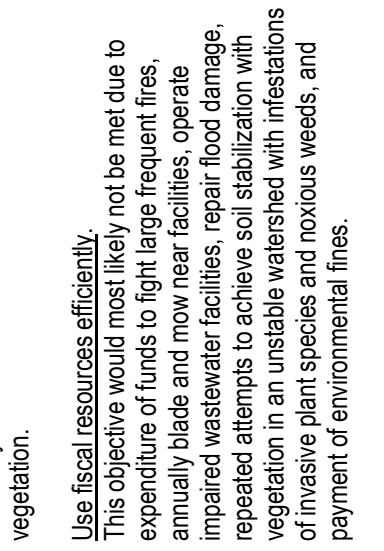 & & 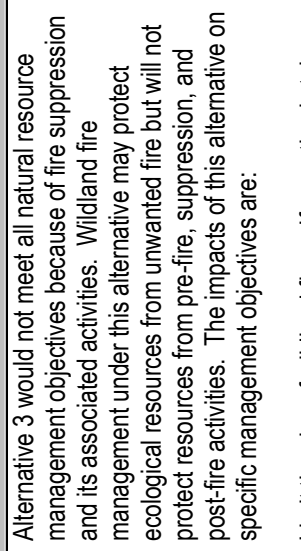 & 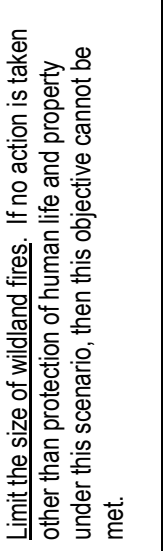 \\
\hline 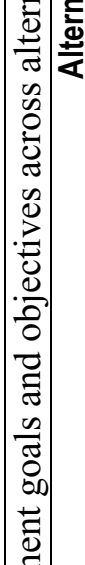 & 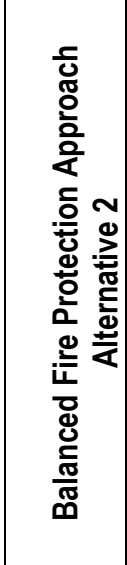 & 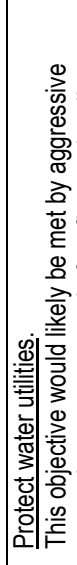 & 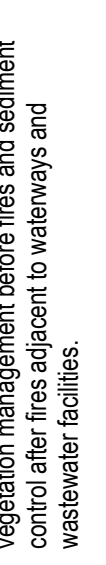 & 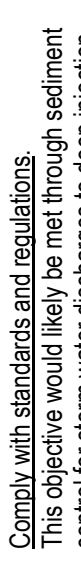 & 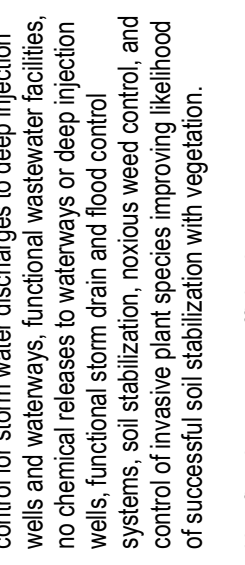 & 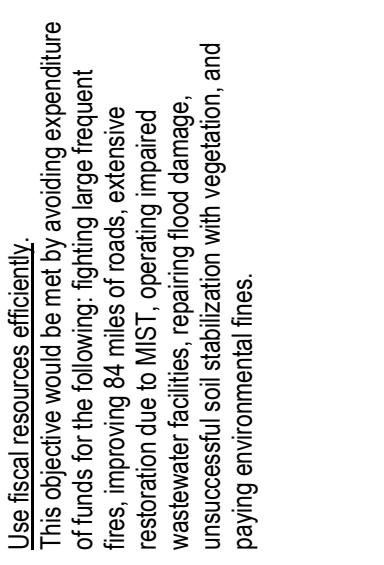 & & 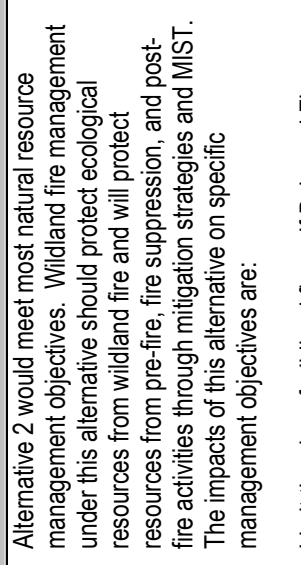 & 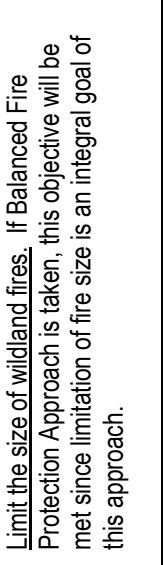 \\
\hline 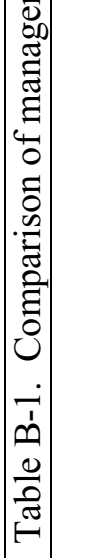 & 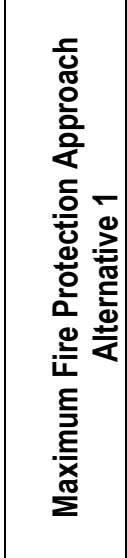 & 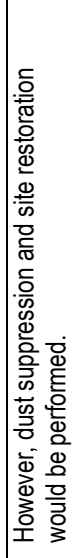 & 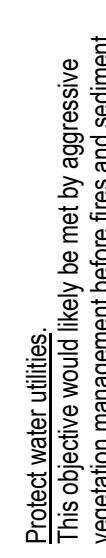 & & 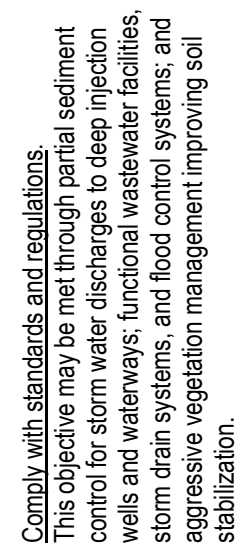 & 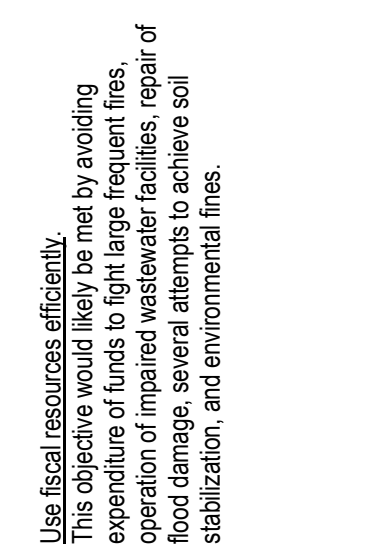 & 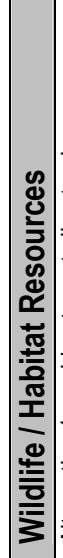 & 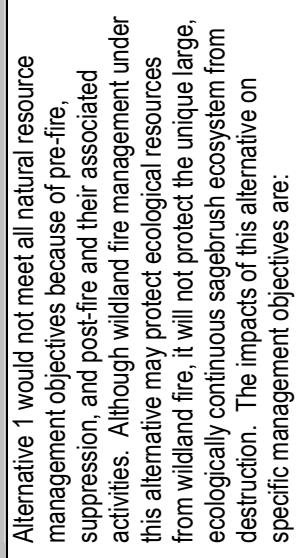 & 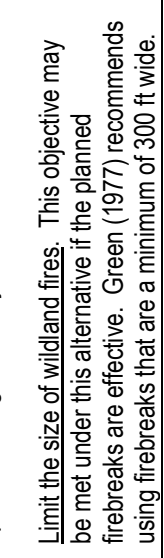 \\
\hline
\end{tabular}




\begin{tabular}{|c|c|c|c|c|c|c|c|c|c|c|c|}
\hline \multirow{2}{*}{\multicolumn{2}{|c|}{ 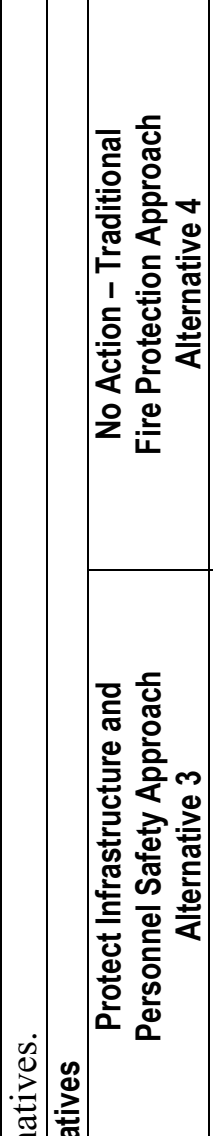 }} & \multicolumn{5}{|c|}{ 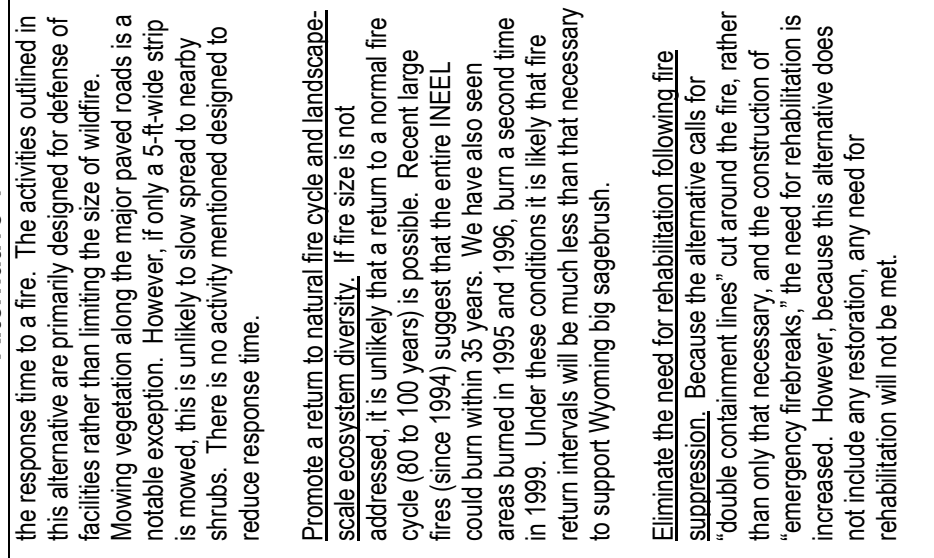 } & \multicolumn{3}{|c|}{ 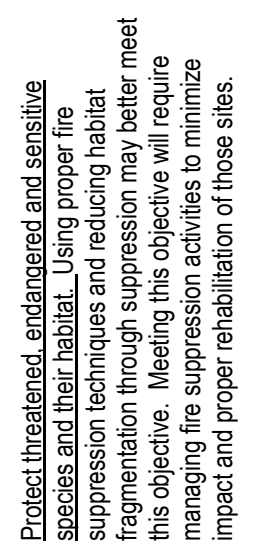 } & \multicolumn{2}{|c|}{ 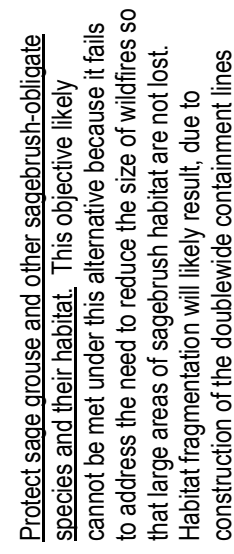 } \\
\hline & & 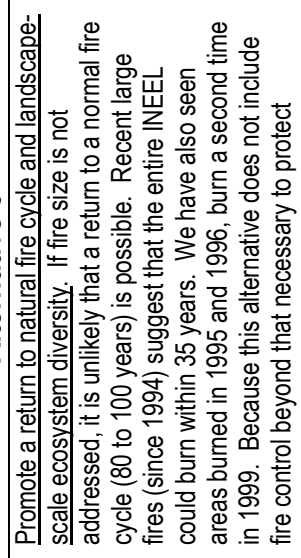 & 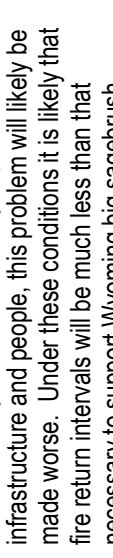 & 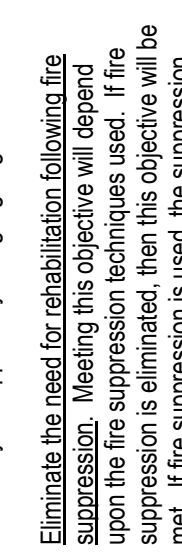 & 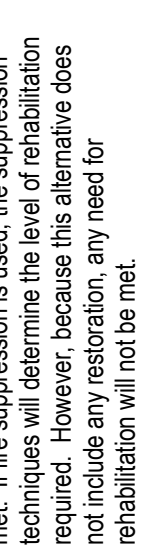 & 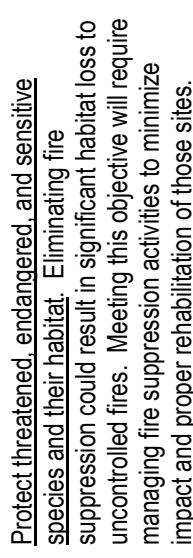 & & & & 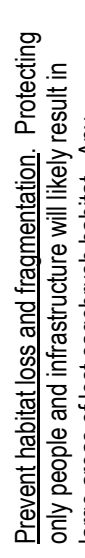 & 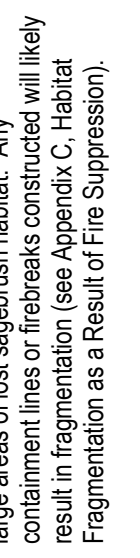 \\
\hline 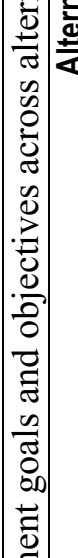 & 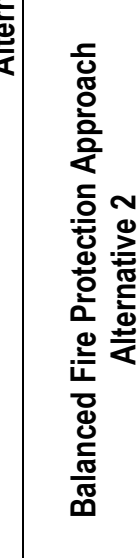 & 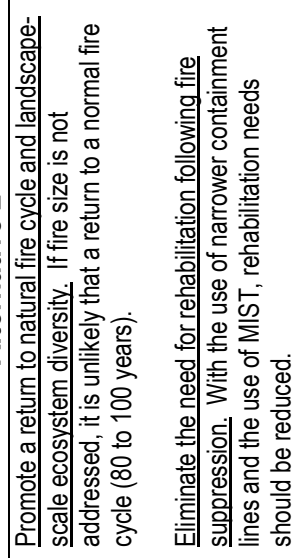 & 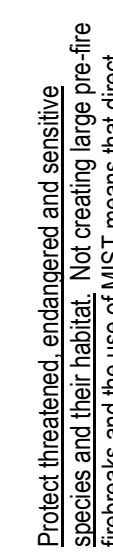 & 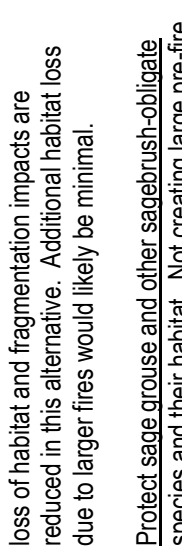 & 苑 & 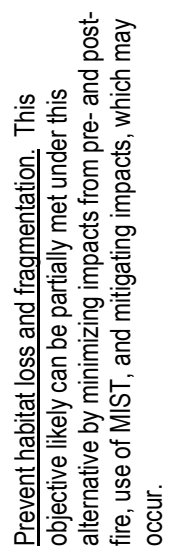 & 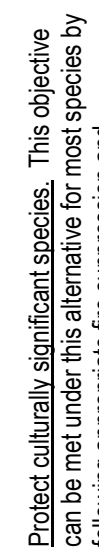 & & & & \\
\hline 4 & 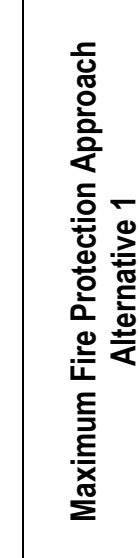 & 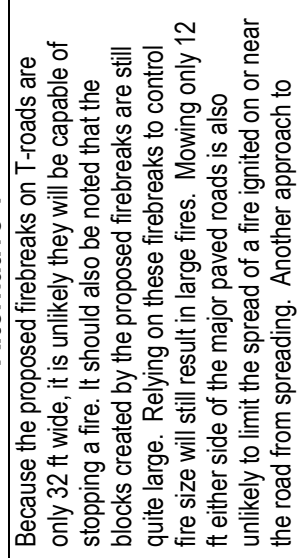 & 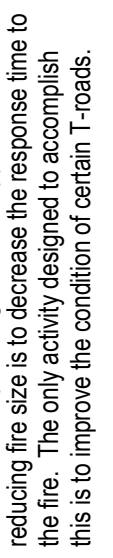 & 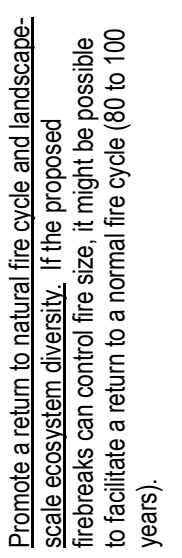 & 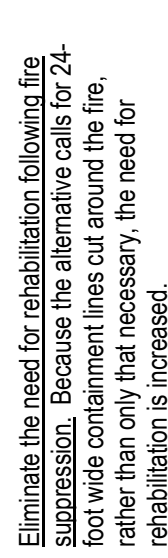 & 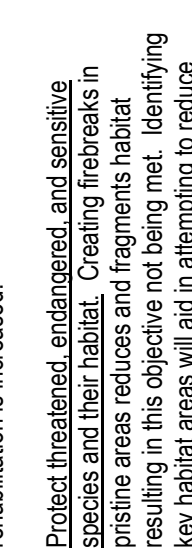 & & 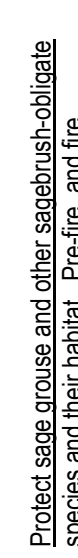 & & & 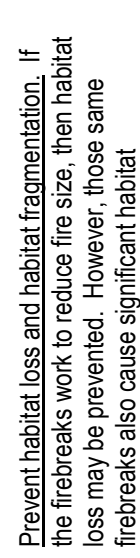 \\
\hline
\end{tabular}




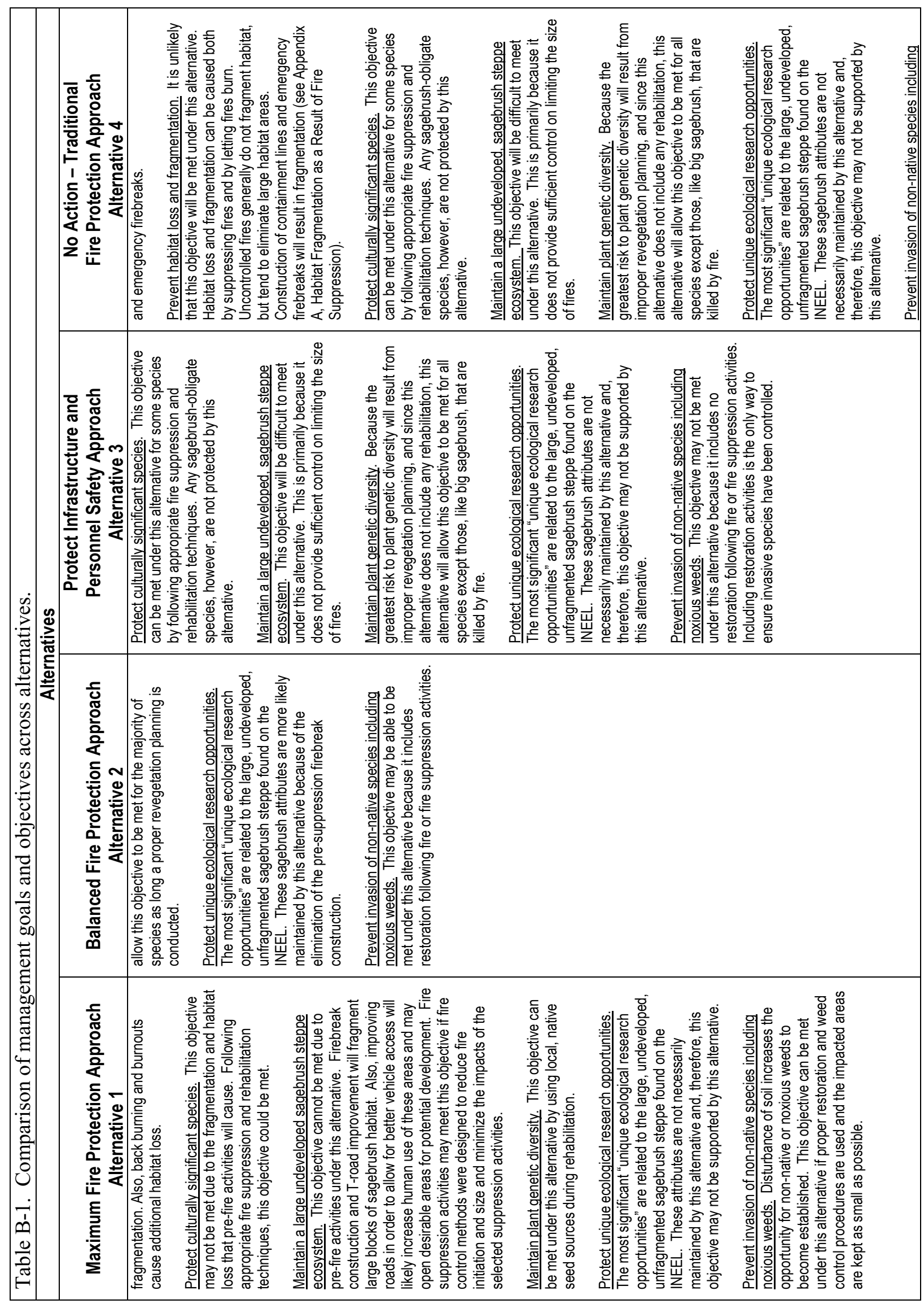




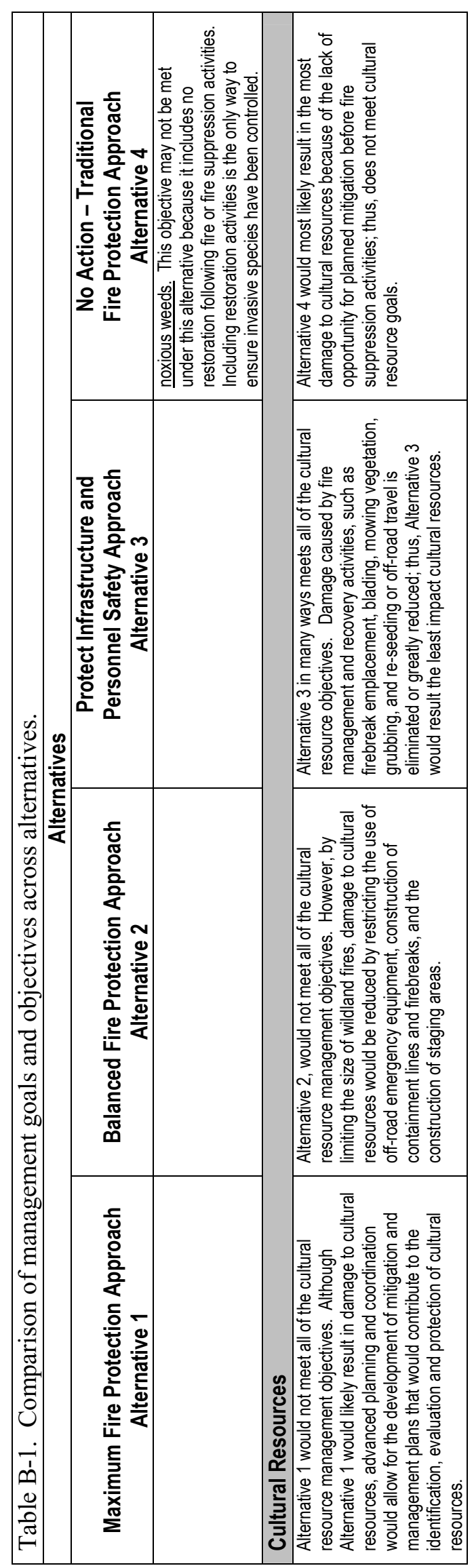




\title{
APPENDIX C - HABITAT FRAGMENTATION
}

\section{HABITAT FRAGMENTATION AS A RESULT OF FIRE SUPPRESSION IMPLICATIONS FOR WILDLAND FIRE MANAGEMENT ON THE IDAHO NATIONAL ENGINEERING AND ENVIRONMENTAL LABORATORY}

\author{
Douglas K. Halford
}

S.M. Stoller Corp.

\section{FIRE SUPPRESSION USING FIRE LINES}

This discussion focuses on the ecological impacts of fire suppression using fire lines on the Idaho National Engineering and Environmental Laboratory (INEEL). The widths of many fire lines are equivalent to roads and for this analyses roads and fire lines will be considered interchangeably.

Some suppression activities leave scars on the landscape that can take longer to heal than the direct effects of fire. Yet, at times, mechanical equipment may be necessary to control a fire and protect life and property. Fire management plans should state when, where, and under what conditions different types of mechanized equipment may be utilized. Fire line construction can have long-term impacts on resources. Minimizing the effect and mitigation following fires are important and necessary parts of the suppression action (Council of the Society of American Foresters 1997).

Burning creates gaps in vegetation, as does bulldozing, but it is possible that soil disturbance created by bulldozer trails is the limiting factor required for the promotion and germination of certain exotic species ${ }^{1}$. The construction of bulldozer fire lines leads to severe fragmentation of native habitat (see discussion below) and compaction of soil; providing increased avenues for weed transport and increased edge effects (Caling and Adams 1999).

Soil degradation may occur as a result of soil compaction. Soil compaction may have a serious negative impact on soil structure and vegetation recovery, which in turn, may impact the ecosystem as a whole. Environmental disruption by soil compaction is a long-term event; as the recovery of compacted sandy soils (sandy soils are more susceptible, and recover more slowly than clay or wetter soils), which are common on the Idaho National Engineering Laboratory (Olson et al. 1995), is extremely slow and can take longer than 50 years (Caling and Adams 1999). Weed invasion of disturbed areas has been linked to changes in soil properties (Zink et al. 1995).

Fire management must include pre-fire planning, planning for management during wildfire, and post-fire planning that includes rehabilitation (Caling and Adams 1999). Continuing the current management practices of suppressing all wildland fires will eventually result in increased areas of old, decadent stands in the sagebrush-grass (Artemisia sp.) community that provides conditions for more high-intensity fires that are harder to manage and control (Bureau of Land Management 2001).

\section{Habitat Fragmentation}

This is a review of the potential impacts of habitat fragmentation caused by fire and fire suppression, particularly fire lines and roads. Roads and fire lines fragment plant and animal populations (Noss

\footnotetext{
${ }^{1}$ Increased edges can result in microclimatic changes in light, temperature, wind, humidity, and incidence of fire. Each of these effects can have a significant impact upon the number and kind of species associated with the edge.
} 
2001). Much of the available literature discusses fragmentation of forest ecosystems. However, it is plausible that many of the ecological principles from forest fragmentation are applicable to rangeland fragmentation. The improper management and control of rangeland fires can therefore increase habitat fragmentation and exacerbate the associated impacts.

Habitat fragmentation is the process whereby a large, continuous area of habitat is both reduced in area and divided into two or more fragments (Wilcove et al. 1996; Schonewald-Cox and Buechner 1992; Reed et al. 1996; Theobald 1998). Fragmentation can occur when area is reduced to only a minor degree if the original habitat is divided by roads, canals, fire lanes, or other barriers to free movement of species (Primack 1998).

Habitat fragmentation leads to increasing edge effects, loss of species diversity, alterations in natural disturbance regimes, and alterations in ecosystem functioning (Caling and Adams 1999). Habitat fragments differ from original habitat in two important ways: 1) fragments have a greater amount of edge for the area of habitat, and 2) the center of each fragment is closer to the edge (Primack 1998).

Changes in the microenvironment at the fragment edge can result from habitat fragmentation. Some of the more important edge effects include microclimate changes in light, temperature, wind, humidity, decreased soil moisture, and incidence of fire (Shelhas and Greenberg 1996; Laurance and Bierregaard 1997; Reed et al. 1996). Each of these edge effects can have a significant impact upon the vitality and composition of species in the fragment and increased wind, lower humidity, and higher temperatures make fires more likely (Primack 1998). Edges produced by roads and fire lines can also increase nest parasitism by brown-headed cowbirds (Molothrus ater). Brown-headed cowbirds, the only obligate brood parasite in North America, feed primarily in open areas, but use perches to watch for nest building activities. Edge habitats are perfect for their needs (Brittingham and Temple 1983) and brood parasitism increases on edges and in fragmented habitats (Belthoff and Rideout 2000).

Fragmentation affects animal populations in a variety of ways, including decreased species diversity and lower densities of some species in the resulting smaller patches (Reed et al. 1996). Some species of animals refuse to cross barriers as wide as a road. For these species, a road or fire line effectively cuts the population in half. A network of roads or fire lines fragments the population even further (Noss 2001). In addition to direct loss of shrub habitats, responses of shrub-obligate species of wildlife will be related to dispersal capabilities and populations my not persist in landscapes of increasingly fragmented patches of sagebrush after disturbance (Braun et al. 1976; Knick and Rotenberry 1995; Knick and Dyer 1997).

For example, fragmentation of sagebrush communities poses a threat to populations of pygmy rabbits (Brachylagus idahoensis) because dispersal potential is limited (Weiss and Verts 1984). Gates (1983) found that although some pygmy rabbits dispersed from a fire, predators killed most. Sage grouse (Centrocercus urophasianus), sagebrush obligates, are totally dependent on sagebrush habitat (Benson et al. 1991) and removal of sagebrush has a negative impact on the value for winter habitat (Gates 1983). Good winter range provides sage grouse with access to sagebrush under all snow conditions. Sage grouse only eat sagebrush during the winter and often use relatively open habitats with $10-25 \%$ sagebrush canopy cover and an average height of $25-35 \mathrm{~cm}$ above the snow.

The quality and quantity of breeding and winter habitat have declined during the 1980's and 1990's because of prolonged drought, fires and agricultural development. Vast areas that were once sagebrush/bunchgrass habitats are now dominated by cheatgrass (Bromus tectorum), with little or no sagebrush over story, making population recovery difficult. 
Many sage grouse populations are migratory and birds may move $100 \mathrm{~km}$ or more between seasonal ranges. Sage grouse have a relatively low reproductive rate compared to other game bird species so populations do not recover very fast following optimal conditions (Schroeder 1999).

Roads fragment plant populations and facilitate the spread of invasive animals, insects and plants. Many of the weedy plants that dominate and disperse along roadsides are exotics. In some cases, these species, such as cheatgrass, spread from roadsides into adjacent native communities (Noss 2001). Exotic species disrupt natural ecosystem processes and the species that depend on them. Exotic plants have been shown to replace native under story vegetation, inhibit seed regeneration, and change soils nutrient cycling. Some weeds can cause higher erosion rates or change fire regimes.

In shrub-steppe ecosystems, invading weeds, which were usually non-mycorrhizal, disrupted succession of native species, $99 \%$ of which were mycorrhizal -dependent. Also, fires have become more common and extensive in sagebrush ecosystems invaded by cheatgrass (Natural Resources Defense Council 2001). Presence of cheatgrass along edges (fire lines and roads) may allow it to invade burned patches, increasing the likelihood of fire spread into adjacent sagebrush patches, further fragmenting the ecosystem (Knick and Rotenberry 1997).

Disturbances such as fire and roads can increase the distance between remaining shrub patches that provide seed sources (Knick and Rotenberry 1997). The dominant shrub on the INEEL, big sagebrush $(A$. tridentata), does not re-sprout from crown or roots following fire (Young and Evans 1978). Thus, natural regeneration of these shrub lands could be severely limited by availability and dispersion of seed sources. Dispersal of sagebrush is primarily wind driven and occurs largely within $30 \mathrm{~m}$ of the seed source (Young and Evans 1989).

Studies concerning roads and their influence on habitat fragmentation offer sufficient reason for adopting a precautionary stance toward road issues (Brittingham and Temple 1983). Roads (fire lines) precipitate fragmentation by dissecting previously large habitats into smaller ones. As the density of roads in landscapes increases, these effects increase as well. Even though roads occupy a small fraction of the landscape in terms of land area, their influence extends far beyond their immediate boundaries (Reed et al. 1996).

\section{LITERATURE CITED}

Belthoff, J. R. and C. W. Rideout. 2000. Effects of Habitat Fragmentation on Shrub-steppe Birds in Southeastern Idaho. 2000 Interim Report, Boise State University, Boise, Idaho.

Braun, C. E., M. F. Baker, R. L. Eng, J. S. Gashwiler and M. H. Schroeder. 1976. Conservation committee report on effects of alteration of sagebrush communities on the associated avifauna. Wilson Bulletin 88: 165-171.

Brittingham, M. C. and S. A. Temple. 1983. Have cowbirds caused forest songbirds to decline? Bioscience 33: 31-35.

Bureau of Land Management. 2001. Little Snake River Resource Fire Plan. Environmental Assessment. U. S. Department of the Interior, Denver, Colorado.

Caling, T. M. and R. Adams. 1999. Ecological Impacts of Fire Suppression Operations in a Small Vegetation Remnant. Proceedings of the Australia Bushfire Conference, Albury Australia, July 1999. 
Council of the Society of American Foresters. 1997. Position Statement on Fire Management in Forest and Range Ecosystems. http://www.safnet.org/policy/psst/psst20.html

Gates, R. J. 1983. Sage Grouse, Lagomorph and Pronghorn use of a Sagebrush-Grassland Burn Site on the Idaho National Engineering Laboratory. M. S. Thesis, Montana State University, Bozeman, Montana. 135 pages.

Knick, S. T. and D. L. Dyer. 1997. Distribution of black-tailed jackrabbit habitat determined by Geographical Information Systems in southwestern Idaho. J. Wildlife Manage. 61: 75-86.

Knick, S. T. and J. T. Rotenberry. 1995. Landscape characteristics of fragmented shrubsteppe habitats and breeding passerine birds. Conservation Biology 9: 1059-1071.

Knick, S. T. and J. T. Rotenberry. 1997. Landscape characteristics of disturbed shrubsteppe habitats in southwestern Idaho. Landscape Ecology 12: 287-297.

Laurance, W. F. and R. O. Bierregaard, Jr. (eds.). 1997. Tropical Forest Remnants: Ecology,

Management and Conservation of Fragmented Communities. The University of Chicago Press, Chicago.

Natural Resources Defense Council. 2001. The Adverse Ecological Impacts of Roads and Logging. www.nrdc.org/land/forests/roads/summ.asp.

Noss, R. 2000. The Ecological Effects of Roads. www.eco-action.org/dt/roads.html Olson, G. L., D. J. Jeppesen and R. D. Lee. 1995. The Status of Soil Mapping for the Idaho National Engineering Laboratory. INEL-95/0051. Lockheed Idaho Technologies Co., Idaho Falls, Idaho.

Primack, R. B. 1998. Essentials of Conservation Biology, Second Edition. Sinauer Associates, Inc., Sunderland, Massachusetts.

Reed, R. A., J. Johnson-Barnard and W. L. Baker. 1996. Contribution of roads to forest fragmentation in the Rocky Mountains. Conservation Biology 10: 1098-1107.

Schonewald-Cox, C. M. and M. Buechner. 1992. Park protection and public roads. In P. L. Fiedler and S. K. Jains (eds.), Conservation Biology: The Theory and Practice of Nature Conservation, Preservation and Management, pp. 373-396. Chapman Hall, New York.

Schroeder, M. A. 1999. Population Ecology and Habitat Needs. In Northern Sage Grouse Status Conference Proceedings, January 14-15, 1999, Boise, Idaho.

Shelhas, J. and R. Greenberg (eds.). 1996. Forest Patches in Tropical Landscapes. Island Press, Washington, D. C.

Theobald, D. M. 1998. Tools Available for Measuring Habitat Fragmentation. Presented at the Colorado Chapter of the Wildlife Society Annual Meeting, January 22, 1998, Grand Junction, Colorado.

Weiss, N. T. and B. J. Verts. 1984. Habitat and distribution of pygmy rabbits (Sylvilagus idahoensis) in Oregon. Great Basin Naturalist 44(4): 563-571.

Wilcove, D., M. J. Bean, R. Bonnie and M. McMillan. 1996. Rebuilding the Ark: Toward a More Effective Endangered Species Act for Private Land. Environmental Defense Fund, Washington, D. C. 
Young, J. A. and R. A. Evans. 1978. Population dynamics after wildfires in sagebrush grasslands. J. of Range Manage. 31: 283-289.

Young, J. A. and R. A. Evans. 1989. Dispersal and germination of big sagebrush (Artemisia tridentata) seeds. Weed Science 37: 201-206.

Zink, T. A., M. F. Allen, B. Heindl-Tenhunen, and E. B. Allen. 1995. The effect of corridor disturbance on an ecological reserve. Restoration Ecology 3: 304-310. 


\section{APPENDIX D - COMMENT RESPONSE}

The Department of Energy - Idaho Operations Office made the draft EA available to the public for review and comment from September 16 to October 16, 2002. DOE-ID received ten comment documents during the comment period. The five comments from the public include: two comments suggesting that DOE choose the Maximum Fire Protection Approach (Alternative 1) as the preferred alternative, two comments providing suggestions on how to control fire on the INEEL, and one comment providing information relative to the number of fires on the INEEL over this individual's 30-year employment at the Site. None of these comments required any changes to the environmental assessment. DOE thanks those individuals for their comments.

DOE-ID also received comments from the following federal and state agencies and conservation groups:

- September 20, 2002, Letter from Monte D. Wilson, Chair, Citizens Advisory Board, Idaho National Engineering and Environmental Laboratory, Idaho Falls, ID.

- October 9, 2002, Letter from Ms. Deb Mignogno, Supervisor, U. S. Fish and Wildlife Service, Eastern Idaho Field Office, Pocatello, ID.

- October 9, 2002, Letter from Robert J. Sabin, Regional Supervisor, Idaho Department of Fish and Game, Idaho Falls, ID.

- October 15, 2002, Email from Mr. Ken Thacker, Sagebrush Steppe Ecosystem Reserve Leader, Bureau of Land Management, Idaho Falls, ID.

- October 22, 2002, Letter from Trish Klahr, Chief Conservation Scientist, Nature Conservancy, Sun Valley, ID.

The following comments and responses are grouped by agency. In addition, where applicable the comment response identifies changes to the EA and their location. As stated earlier, the comments from the public did not require any changes to the EA.

\begin{tabular}{|l|l|}
\hline \multicolumn{1}{|c|}{ Comments and Responses } \\
\hline COMMENTS FROM THE CITIZENS ADVISORY BOARD (CAB) \\
\hline $\begin{array}{l}\text { CAB COMMENT (1) DOE use } \\
\text { Approach whenever possible. }\end{array}$ & $\begin{array}{l}\text { RESPONSE: DOE has selected Alternative 2, the "Balanced Fire Protection Approach" } \\
\text { as the preferred alternative in the Finding of No Significant Impacts. } \\
\text { We did not change the EA as a result of this comment. }\end{array}$ \\
\hline $\begin{array}{l}\text { CAB COMMENT (2) DOE and } \\
\text { pLM work together on pre-fire } \\
\text { planning and fire suppression } \\
\text { same suppression approach and } \\
\text { protection methods for the facilities. }\end{array}$ & $\begin{array}{l}\text { RESPONSE: Section 1.3 describes the relationship of this EA to BLM's EIS and the } \\
\text { Sagebrush Steppe Ecosystem Reserve. DOE and BLM are coordinating efforts. That } \\
\text { coordination lead to an initial decision to include the INEEL in the BLM EIS and } \\
\text { identify it as a Category "B" Polygon meaning that wildland fire is not desired and } \\
\text { aggressive fire suppression tactics would be employed. However, if DOE makes a } \\
\text { decision based on this EA that would change the "B" polygon designation, DOE will } \\
\text { work with BLM to revise the designation in their EIS. }\end{array}$ \\
$\begin{array}{l}\text { If the management plan and associated EA for the Sagebrush Steppe Ecosystem Reserve } \\
\text { indicates the need for a wildland fire strategy that differs from an alternative selected } \\
\text { based on this EA, that strategy would be incorporated into the INEEL's wildland fire } \\
\text { management. }\end{array}$ \\
$\begin{array}{l}\text { CAB COMMENT (3) DOE include } \\
\text { Committee as part of all the } \\
\text { alternatives. }\end{array}$ & $\begin{array}{l}\text { RESPONSE: The purpose of the Wildland Fire Management Committee (WLFM } \\
\text { Committee) is to provide recommendation to DOE for pre-fire and post-fire activities } \\
\text { (see Section 2.1). Alternative 4 "Traditional Fire Protection Approach" is the no action } \\
\text { alternative, and as such describes the current wildland fire management strategy, and } \\
\text { does not include a WLFM Committee. Few pre- and post-fire activities under }\end{array}$ \\
\hline
\end{tabular}




\begin{tabular}{|c|c|}
\hline & $\begin{array}{l}\text { Alternative } 3 \text { "Protect Infrastructure and Personnel Safety Approach" are closely } \\
\text { associated with protection of facilities, and would likely not need a WLFM Committee to } \\
\text { provide recommendations. } \\
\text { We did not change the EA as a result of this comment. }\end{array}$ \\
\hline \multicolumn{2}{|c|}{ COMMENTS FROM THE U. S. FISH AND WILDLIFE SERVICE (FWS) } \\
\hline $\begin{array}{l}\text { FWS COMMENT (1) DOE } \\
\text { consider and discuss threatened and } \\
\text { endangered species that occur or } \\
\text { may occur on the INEEL, such as the } \\
\text { gray wolf, bald eagle, and Ute } \\
\text { ladies'-tresses and species of } \\
\text { concern sage grouse, yellow-billed } \\
\text { cuckoos, and pygmy rabbits. }\end{array}$ & $\begin{array}{l}\text { RESPONSE: There have been no confirmed sightings of the gray wolf on the INEEL } \\
\text { and we concluded that it was unlikely there would be negative impacts to this species. } \\
\text { Bald eagles have been known to winter on and near the INEEL. We have no records } \\
\text { indicating that they nest on the INEEL, and believe that nesting habitat for this species } \\
\text { does not exist on the INEEL. Wintering bald eagles can be found on the INEEL perched } \\
\text { on power line poles but are mainly found along the northwest boundary of the INEEL in } \\
\text { the vicinity of Howe. While in this area, the eagles are foraging primarily on agricultural } \\
\text { fields in that area. Foraging perches on the INEEL in that vicinity are limited to power } \\
\text { line poles. Protection of those poles is discussed elsewhere in this document. There has } \\
\text { been speculation that the Spreading Areas near RWMC could be an important wintering } \\
\text { area when the Big Lost River is flowing and the Spreading Areas contain enough water } \\
\text { to attract ducks. It is unlikely that summertime fires or fire fighting would have any } \\
\text { impact on this potential resource. } \\
\text { Ute ladies tresses is listed for Bonneville and Jefferson counties. The areas of the } \\
\text { INEEL that occur in these two counties are almost entirely sagebrush steppe. It is highly } \\
\text { unlikely that suitable habitat for this species exists in those areas and impact to this } \\
\text { species or its habitat due to wildland fire or fire fighting is unlikely. } \\
\text { The yellow-billed cuckoo requires large blocks of riparian habitat. Riparian habitat on } \\
\text { the INEEL is restricted to a narrow band along the Big Lost River. None of this habitat } \\
\text { could be described as the kind of riparian woodland necessary for yellow-billed cuckoo } \\
\text { habitat. It is unlikely that wildland fire or fire fighting would have impacts to this } \\
\text { species or its habitat. } \\
\text { Potential impacts to sage grouse and pygmy rabbits and their habitats were addressed } \\
\text { along with all other sagebrush obligate species. The need to maintain large expanses of } \\
\text { unfragmented sagebrush steppe, required for many of the INEEL "species of concern," } \\
\text { was the focus for much of the discussion of the environmental consequences to } \\
\text { wildlife/habitat resources in this document. } \\
\text { We did not change the EA as a result of this comment. }\end{array}$ \\
\hline $\begin{array}{l}\text { FWS COMMENT (2) DOE limit } \\
\text { the use foam and fire retardants as } \\
\text { fire suppression activities to prevent } \\
\text { potential long-term impacts to } \\
\text { ecological resources. }\end{array}$ & $\begin{array}{l}\text { RESPONSE: In this document we discussed the science regarding the known effects of } \\
\text { fire retardants on sagebrush steppe vegetation. As reported, there appear to be no short- } \\
\text { term effects to sagebrush communities. We did not find any documentation concerning } \\
\text { the long-term effects of fire retardants in sagebrush steppe and, therefore, the potential } \\
\text { long-term impacts of their use cannot be estimated. However, the alternatives to using } \\
\text { fire retardants do have well recognized long-term impacts. These alternatives include } \\
\text { increased loss of sagebrush habitat due directly to fires and the impacts of creating } \\
\text { containment lines around those larger fires as described elsewhere in this document. See } \\
\text { Section } 4 \text { of the EA and Table } 4.2 \text {. } \\
\text { We did not change the EA as a result of this comment. }\end{array}$ \\
\hline $\begin{array}{l}\text { FWS COMMENT (3) DOE keep } \\
\text { cultural and historical resource } \\
\text { impacts as low as possible. }\end{array}$ & $\begin{array}{l}\text { RESPONSE: The EA states that the cultural resource management goal is to reduce or } \\
\text { eliminate impacts to cultural resources from INEEL activities, including wildland fires } \\
\text { (see Section 1.4.5). DOE is recommending Alternative 2, the "Balanced Fire Protection } \\
\text { Approach" as the preferred alternative in the Finding of No Significant Impacts. The } \\
\text { analysis in the EA indicates that Alternative } 2 \text { meets the cultural resource management } \\
\text { objectives (see Table 4-2). } \\
\text { We did not change the EA as a result of this comment. }\end{array}$ \\
\hline \multicolumn{2}{|c|}{ COMMENTS FROM IDAHO DEPARTMENT OF FISH AND GAME (IDFG) } \\
\hline $\begin{array}{l}\text { IDFG COMMENT (1) soil } \\
\text { disturbing activities like road }\end{array}$ & $\begin{array}{l}\text { RESPONSE: In Section } 4.1 .3 \text { of this EA, we discuss the increased probability of weed } \\
\text { invasion associated with Fuel Management Zones, Upgrading Unimproved Roads, }\end{array}$ \\
\hline
\end{tabular}


widening should be avoided. The IDFG is concerned...that cheatgrass and other undesired plant species will become established in the disturbed soils along these roads. The invasive species are usually highly fire prone and could lead to more frequent wildfire.
Defensible Space and Fire Suppression Activities. Although we did discuss the relationship between cheatgrass invasion and increased fire frequency elsewhere in this document (Section 3.4 and Appendix A), we did not make the direct connection in the Environmental Consequences section between the invasion of annual weeds associated with Fuel Management Zones, Defensible Space and Fire Suppression Activities, and the increased likelihood of ignition and the potential for increased fire frequency. The longterm potential for increased fire frequency, higher risk of ignition, and potential for more and larger fires associated with these soil-disturbing activities has been considered.

We did not change the EA as a result of this comment.

\section{IDFG COMMENTS}

(2) greenstriping only be considered around buildings and other facilities.

\section{IDFG COMMENTS (3) post-fire} activities not include the burning out of sagebrush steppe areas. Intact sagebrush steppe should be left in place.

IDFG COMMENTS (4)

recommended that burned areas should at least be seeded with sagebrush to decrease the timeframe for sagebrush to re-colonize the area.

\section{RESPONSE: We have removed references to greenstriping from the EA.}

RESPONSE: Burning sagebrush within the fire perimeter would only be done to when necessary to improve the effectiveness of a containment line. The practice is not included in any alternative as a post-fire activity (see Section 2.1.2).

We did not change the EA as a result of this comment.

RESPONSE: The Department understands and agrees with the need to decrease the timeframe for sagebrush reestablishment after a wildland fire. Options to reduce that timeframe include aerial seeding, various ground drill planting techniques of seeds, and planting of seedlings. The first two options have been repeatedly tried in various areas of the west, including on the INEEL. To date, reestablishment by those techniques has not proven successful. Aerial seeding versus natural recovery is being studied on the INEEL under a long-term research project. DOE will continue to assess new data regarding the reestablishment of sagebrush and prefers to keep the recovery options open on whether the INEEL uses planting seedlings, developing specialized drills for seed planting, special timing of aerial seeding or a new technology yet to be developed. DOE will evaluate the latest data available when deciding what method to use for future restoration activities.

We did not change the EA as a result of this comment

\section{COMMENTS FROM THE BUREAU OF LAND MANGEMENT (BLM)}

BLM COMMENT (1) that the EA $\quad$ RESPONSE: See response to IDFG Comment (1).

does not adequately reflect potential impact and threat to sagebrush habitat from the invasion of weeds, especially cheatgrass following prefire and suppression activities.

\section{BLM COMMENT (2) providing} the acres disturbed by fuel management and upgrading unimproved roads for each alterative. BLM COMMENT (3) revising the values in the Evaluation Matrix (Table 4-2) related to "Maintain plant genetic diversity" and "Prevent invasion of non-native species including noxious weeds."
We did not change the EA as a result of this comment.

RESPONSE: We concur and have added the number of acres disturbed by fuel management and upgrading unimproved roads for each alternative (see Table 2-1).

RESPONSE: We concur and have revised the values to those natural resource objectives (see Table 4-2).

\section{COMMENTS FROM THE NATURE CONSERVANCY (NC)}

NC COMMENT (1) adding as a management objective to prevent and/or minimize the introduction of fuels onto the INEEL specifically referring to cheatgrass invasion resulting from soil disturbance.
RESPONSE: We agree that preventing the invasion by cheatgrass is critical to any wildland fire management plan for sagebrush steppe and that soil disturbance is the primary risk factor for cheatgrass invasion on the INEEL. We also agree that achieving many, if not most, of the Management Objectives (1.4.2 through 1.4.5) can be met through minimizing soil disturbance and that is reflected in the discussions of environmental consequences in Section 4. Although we recognize it as an important method for achieving our management objectives, we did not consider it a purpose or target that we hope to achieve with our management. 


\begin{tabular}{|c|c|}
\hline & We did not change the EA as a result of this comment. \\
\hline $\begin{array}{l}\text { NC COMMENT (2) that the EA } \\
\text { provide further justification for } \\
\text { "Unimproved Road Upgrade" action } \\
\text { in Alternative } 2 \text {. }\end{array}$ & $\begin{array}{l}\text { RESPONSE: The criterion for upgrading unimproved roads is to make them passable by } \\
4 \times 4 \text { equipment in part, to improve fire fighting access and response times. The primary } \\
\text { impediment to } 4 \times 4 \text { travel on two-track roads is deep rutting. Upgrading will be primarily } \\
\text { limited to filling these ruts with gravel. No soil disturbance will be allowed in this } \\
\text { process without further environmental review. } \\
\text { We added a note a note to the EA clarifying upgrading unimproved roads (See Table 2-1, } \\
\text { Pre-Fire Actions, Alternative 2, Unimproved Road Upgrades and Section 2.1.1, Road } \\
\text { Improvements). }\end{array}$ \\
\hline $\begin{array}{l}\text { NC COMMENT (3) the EA identify } \\
\text { "Natural Burn Areas" where } \\
\text { naturally occurring wildland fires } \\
\text { could burn without soil-disturbing } \\
\text { interference. }\end{array}$ & $\begin{array}{l}\text { RESPONSE: We have chosen not to specify any let-burn areas except as a default } \\
\text { condition for Alternative } 3 \text { where there is no objective to contain any fire and only } \\
\text { facilities would be protected. Guidelines for sage grouse management recommend } \\
\text { protecting all sagebrush from fire. There are distinct trade-offs between aggressively } \\
\text { fighting fire to limit the amount of sagebrush habitat lost and increasing the likelihood of } \\
\text { weed invasions due to soil disturbance associated with constructing containment lines. } \\
\text { The most important need is to develop a post-fire rehabilitation plan that focuses on } \\
\text { preventing weed invasion. Since } 1994 \text {, almost one-third of the sagebrush habitat on the } \\
\text { INEEL has been lost to fire. At this time, protecting the remaining sagebrush habitat is } \\
\text { now of great importance. } \\
\text { We did not change the EA as a result of this comment. }\end{array}$ \\
\hline $\begin{array}{l}\text { NC COMMENT (4) clarifying the } \\
\text { term "unwanted wildland fire." A } \\
\text { better term might be "human-caused } \\
\text { wildland fires" as opposed to } \\
\text { "naturally ignited wildfires." }\end{array}$ & $\begin{array}{l}\text { RESPONSE: We chose to use the term unwanted to describe fires that are not burning } \\
\text { according to a prescription regardless of the ignition source. } \\
\text { We did not change the EA as a result of this comment. }\end{array}$ \\
\hline
\end{tabular}

